\title{
ARTICLES
}

\section{RIGHTING THE BALANCE: AN INQUIRY INTO THE FOUNDATIONS AND LIMITS OF FREEDOM OF EXPRESSION}

\author{
STEVEN J. HeYMAN *

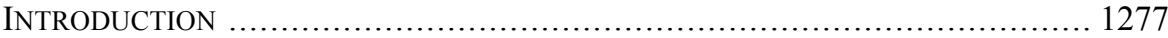 \\ I. NATURAL Rights, SOCIAL WELFARE, AND THE FIRST \\ AMENDMENT ..................................................................... 1280 \\ A. The Natural Rights Origins of the First Amendment .............. 1282 \\ 1. The English Background ...................................... 1282 \\ 2. Natural Rights and the Founding of the American Re- \\ publics ................................................................ 1287 \\ B. Free Speech, Natural Rights, and the Fourteenth Amend- \\ ment ............................................................... 1296 \\ C. The Transformation of Free Speech Theory ........................ 1299 \\ D. Classical versus Modern Free Speech Theory ........................ 1305 \\ E. The Dilemma of Modern First Amendment Theory ................. 1307

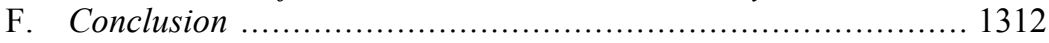 \\ II. FREE SPEECH IN A FrAMEWORK OF RIGHTS ............................. 1313

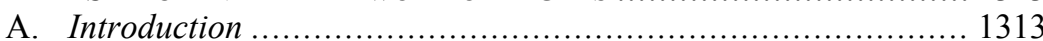 \\ 1. Liberty and Rights .............................................. 1313 \\ 2. The Basic Model ................................................. 1315 \\ B. Free Speech and External Rights .................................. 1317
}

\footnotetext{
* Associate Professor of Law, Chicago-Kent College of Law, Illinois Institute of Technology. A.B. 1979, Harvard College; J.D. 1984, Harvard Law School. This Article was presented at Chicago-Kent faculty workshops and at the inaugural meeting of the Working Group on Law, Culture, and the Humanities, held at Georgetown University Law Center in March 1998. I am grateful to the participants in those sessions, especially Vincent Blasi, Carol Greenhouse, Charles Lawrence, Milton Regan, and Susan Williams, for their thoughtful comments, and to Alison Baldwin, Anita Bernstein, Jacob Corré, Michael Curtis, David Gerber, Carol Miller, Vincent Samar, Steven Wilf, and Richard Wright for their reading of earlier drafts. I also learned much from conversations with Thomas Grey and Robert Post. Kerry Bartell, Jennifer O’Neill, and Lisa Weier provided valuable research assistance. Finally, I would like to express my deep gratitude for the indispensable research support provided by the Norman and Edna Freehling Scholars Fund.
} 
1. Freedom of Speech as an External Right ................... 1318

2. Other Rights ................................................. 1318

C. Free Speech and Rights of Personality ............................ 1323

1. Speech, Thought, and Personality ............................ 1326

a. Speech and Thought as Rights of Personality ........... 1326

b. Free Speech and the Rights of Others .................... 1328

2. Injuries to Personality ......................................... 1329

a. Substantive Injury: Intentional Infliction of Emotional Distress .......................................... 1329

b. Formal Injury: Invasion of Privacy ..................... 1332

c. Injury to Social Personality: Defamation, "False Light," and Misappropriation of Name or

Likeness .............................................. 1336

3. A Response to Some Objections .............................. 1340

D. Free Speech and Community ........................................ 1344

E. Free Speech and the Search for Truth ............................ 1349

III. Conflicts of Rights ............................................. 1355

A. A Three-Fold Inquiry ........................................ 1355

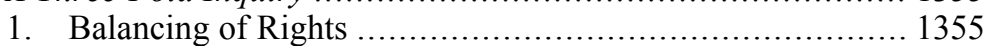

2. Internal Relationships Between Rights .................... 1357

3. The System of Constitutional Liberty ..................... 1358

4. Elaborating the Approach ................................. 1358

B. An Illustration: Defamation and the First Amendment ........... 1359

1. Public Officials .............................................. 1359

2. Public and Private Figures ................................ 1362

C. Conclusion .................................................... 1364

1. The Rights-Based Theory Contrasted with Contemporary First Amendment Jurisprudence: Florida Star v. B.J.F. .................................................... 1364

2. Two Objections ........................................... 1366

a. May Speech Be Restricted to Protect Nonconstitutional Rights? ............................................ 1366

b. Does a Rights-Based Approach Undermine Freedom of Expression? .................................... 1368

IV. ApPLICATIONS ............................................................. 1369

A. Insulting or Fighting Words ....................................... 1369

1. The Chaplinsky Case ........................................ 1369

2. Tendency to Provoke a Breach of the Peace ................. 1370

3. Words That Inflict Injury by Their Very Utterance .......... 1373

4. Conclusion ..................................................... 1374

B. Hate Speech ...................................................... 1375

1. Private Hate Speech ......................................... 1376

a. Should Private Hate Speech Be Protected by the First Amendment? ......................................... 1376

b. Is All Wrongful Speech Equal? Hate Speech and the R.A.V. Decision .................................... 1379

2. Public Hate Speech ........................................ 1382

a. Is Public Hate Speech Wrongful? ......................... 1382

b. Should Public Hate Speech Be Protected Under the 
First Amendment?

1385

3. Conclusion

\section{INTRODUCTION}

In January 1995, a University of Michigan sophomore named Jake Baker posted a short story to an Internet site devoted to sexually explicit fiction. ${ }^{1}$ The story, "Pamela's Ordeal," graphically recounted the narrator's rape, torture, mutilation, and murder of a female student with the same name as one of Baker's classmates. ${ }^{2}$ After being alerted to the story by an alumnus, university officials undertook an inquiry. The investigation revealed that, in addition to writing a number of similar stories, Baker had engaged in an extended e-mail correspondence with another man, in which the two had shared their desires to commit sexual violence against young women, discussed how they would go about it, and made vague plans to meet. $^{3}$

Based on this information, the university suspended Baker and banned him from campus. ${ }^{4}$ Shortly thereafter, he was arrested and charged with violating a federal statute ${ }^{5}$ that makes it unlawful to transmit threatening communications in interstate or foreign commerce. ${ }^{6}$ Although the charges initially included "Pamela's Ordeal," they came to focus on the e-mail correspondence, after prosecutors concluded that it would be too difficult to show that the story constituted a threat. ${ }^{7}$ The case was subsequently dismissed by the district court, which held that Baker's e-mails constituted protected speech under the First Amendment. ${ }^{8}$ Over a vigorous dissent, a panel of the United States Court of Appeals for Sixth Circuit

1 The facts of the incident are recounted in United States v. Baker, 890 F. Supp. 1375, 1379-80 (E.D. Mich. 1995), and United States v. Alkhabaz, 104 F.3d 1492, 1493 (6th Cir. 1997); id. at 1497-99 (Krupansky, J., dissenting), and were widely reported in the media, see, e.g., Megan Garvey, Crossing the Line on the Info Highway, Wash. Post, Mar. 11, 1995, at H1.

2 The story is reproduced in Alkhabaz, 104 F.3d at 1497-98 n.1 (Krupansky, J., dissenting).

3 See id. at 1498; Garvey, supra note 1. Portions of the correspondence are reproduced in Alkhabaz, 104 F.3d at 1499-1501 (Krupansky, J., dissenting).

4 See Garvey, supra note 1.

518 U.S.C. $\$ 875$ (c) (1994).

6 See Garvey, supra note 1. Finding that Baker posed a danger to the community, a federal magistrate initially ordered that he be detained pending trial. See Baker, 890 F. Supp. at 1379. This order was affirmed by both a district judge, see United States v. Baker, No. 95-80106 (D. Mich. Feb. 10, 1995), and the court of appeals, see 48 F.3d 1220 (6th Cir. 1995) (unpublished table decision). Baker was released 29 days later after a psychological evaluation concluded that he was not dangerous. See Baker, 890 F. Supp. at $1379 \&$ n.5.

7 See Baker, 890 F. Supp. at 1380 \& n.6.

8 Id. at $1380-90$. 
affirmed the dismissal, but on the narrower ground that the e-mails did not amount to threats within the meaning of the statute. ${ }^{9}$

The Baker case sparked intense controversy not only within the university and the local community, but also on the Internet. For some, including Catharine A. MacKinnon, Baker's story constituted a form of assaultive speech that was deeply degrading to the woman that it named and threatening to her personal safety. ${ }^{10}$ Such speech, they argued, does not merit protection under the First Amendment. ${ }^{11}$ Others, including officials of the American Civil Liberties Union, responded that however abhorrent the story may have been, it was mere fiction or fantasy which was fully entitled to constitutional protection. ${ }^{12}$

Despite its unusual facts, the Baker incident in many ways is representative of contemporary disputes over the First Amendment. Whether they focus on hate speech, ${ }^{13}$ pornography, ${ }^{14}$ flag burning, ${ }^{15}$ abortion-clinic demonstrations, ${ }^{16}$ publishing the names of rape victims, ${ }^{17}$ tobacco advertising, ${ }^{18}$ violent entertain-

9 See Alkhabaz, 104 F.3d at 1492. The court of appeals expressly declined to address Baker's constitutional claim. See id. at 1493.

10 See, e.g., All Things Considered (National Public Radio broadcast, Mar. 15, 1995), available in LEXIS, News Library, Arcnws File (remarks of Catharine MacKinnon); Garvey, supra note 1 (quoting views of federal prosecutors that Baker's expression constituted threats unprotected by First Amendment).

11 See sources cited supra note 10.

12 See, e.g., Court Upholds E-mail as Free Speech, Agence France Presse, Jan. 30, 1997, available in LEXIS, News Library, Curnws File (quoting Howard Simon, executive director of American Civil Liberties Union of Michigan, asserting that "[e]ven sick fantasies are free speech" protected by First Amendment).

13 See, e.g., R.A.V. v. City of St. Paul, 505 U.S. 377 (1992); Collin v. Smith, 578 F.2d 1197 (7th Cir.), cert. denied, 439 U.S. 916 (1978).

14 See, e.g., American Booksellers Assn. v. Hudnut, 771 F.2d 323 (7th Cir. 1985), aff'd mem., 475 U.S. 1001 (1986).

15 See, e.g., Texas v. Johnson, 491 U.S. 397 (1989).

16 See, e.g., Madsen v. Women's Health Ctr., 512 U.S. 753 (1994).

17 See, e.g., Florida Star v. B.J.F., 491 U.S. 524 (1989).

18 See, e.g., Penn Adver. v. Mayor of Baltimore, 63 F.3d 1318 (4th Cir. 1995) (upholding Baltimore ordinance banning most outdoor advertising of cigarettes), vacated, 518 U.S. 1030 (1996), adopted as amended, 101 F.3d 332 (4th Cir. 1996), cert. denied, 117 S. Ct. 1569 (1997). In August 1996, the U.S. Food and Drug Administration issued regulations imposing substantial restrictions on tobacco advertising. See Regulations Restricting the Sale and Distribution of Cigarettes and Smokeless Tobacco to Protect Children and Adolescents, 61 Fed. Reg. 44,396 (1996). The regulations were recently invalidated by the U.S. Court of Appeals for the Fourth Circuit, which held that the FDA lacks jurisdiction to regulate tobacco products. See Brown \& Williamson Tobacco Corp. v. FDA, 153 F.3d 155 (4th Cir. 1998). The recent settlement between the major tobacco companies and the states contains a variety of restrictions on cigarette advertising and marketing. See Barry Meier, Cigarette Makers and States Draft a \$206 Billion Deal, N.Y. Times, Nov. 14, 1998, at A1. 
ment, ${ }^{19}$ the National Endowment for the Arts, ${ }^{20}$ Internet regulation, ${ }^{21}$ or other issues, such controversies tend to have a common structure. Those who advocate regulation of a particular form of expression contend that it causes substantial harm to individuals, groups, or the community at large. Opponents are often skeptical about the seriousness of this harm. In any event, they argue, the First Amendment denies government the power to prevent such harm through the suppression of speech. ${ }^{22}$

Of course, few people would deny that there are situations in which speech may be regulated without violating the First Amendment. ${ }^{23}$ Yet we have no welldeveloped and generally accepted view of when regulation is legitimate. In the absence of any common ground or standard to appeal to, contemporary free speech disputes often appear to be irresolvable.

It is difficult to see how this impasse can be broken without a more general account of the scope of free expression - a view that integrates both the justifications and the limits of that freedom into a coherent whole. This Article makes a start toward the development of such a theory. Its central thesis is that free speech is a right that is limited by the fundamental rights of other individuals and the community as a whole.

As I show in Part I, this idea was regarded as axiomatic when the First Amendment was adopted. Eighteenth-century Americans understood freedom of speech within the framework of natural rights theory. Free speech was a right inherent in human nature and republican citizenship. Like all such rights, however, it was bounded by the rights of others. Because government was instituted to protect rights, it had an obligation not only to respect liberty of speech, but also to ensure that this liberty was not used to violate other fundamental rights.

In this way the natural rights tradition provided a standard by which to assess the legitimacy of laws regulating free speech. The possibility of such a standard was undermined, however, by the rise of legal positivism and utilitarianism, which repudiated the concept of natural rights. In modern jurisprudence, First Amendment issues are conceived of not as conflicts of rights, but as clashes between free speech and "social interests" - a term within which the rights of others have been

19 See Lawrie Mifflin, Deal on Making Ratings for TV Specify Content, N.Y. TIMES, July 10, 1997, at A1, col. 1.

20 See National Endowment for the Arts v. Finley, 118 S. Ct. 2168 (1998).

21 See Reno v. American Civil Liberties Union, 117 S. Ct. 2329 (1997).

22 It is important to note that those who support or oppose regulation often vary from one issue to another. Thus conservatives often support prohibitions on flag burning, while liberals oppose them; these positions are largely reversed on the regulation of cigarette advertising and anti-abortion demonstrations.

${ }^{23}$ See, e.g., Konigsberg v. State Bar of Calif., 366 U.S. 36, 49-50 n.10 (1961) (Harlan, J.) (observing that an absolutist interpretation of the First Amendment "cannot be reconciled with the law relating to libel, slander, misrepresentation, obscenity, perjury, false advertising, solicitation of crime, complicity by encouragement, conspiracy, and the like"). 
absorbed. There is, however, no clear way to resolve such conflicts. This is a key reason why contemporary First Amendment problems so often appear to involve clashes of irreconcilable values.

The intractability of such problems suggests that we should consider returning to a rights-based conception of the basis and limits of freedom of speech. Part II develops the main outlines of such a theory, drawing both on the natural rights tradition and on our modern understanding of fundamental rights. The discussion begins with an account of rights as grounded in human liberty. Rights represent what it means to be a free person in various spheres of life - not only in relation to the external world, but also in one's inner life and its expression to others, in social relationships and community life, and in the intellectual and spiritual realm. These four elements of liberty correspond to the major justifications that have been advanced for freedom of speech: that it is an aspect of external freedom; that it is essential for individual self-realization; that it is central to democratic selfgovernment; and that it safeguards the search for truth. As I shall show, however, the same principles that underlie freedom of expression also give rise to other rights, such as personal security, privacy, reputation, and citizenship. Because these rights derive from the same grounds as free speech itself, they have the same fundamental status and value. It follows that speech must generally respect them. There are some cases, however, in which the value of free speech justifies overriding other rights. Part III discusses how such problems should be analyzed, taking as an illustration the constitutional law of defamation. This Part concludes by contrasting the rights-based theory with the Supreme Court's current First Amendment jurisprudence, through an exploration of the constitutionality of laws that bar publication of the names of sexual-assault victims.

Part IV brings the rights-based theory to bear on two major controversies: whether the First Amendment should protect "fighting words," and whether it should protect hate speech based on race or other invidious grounds. Finally, we shall return to the controversy over the Jake Baker case.

\section{Natural Rights, Social Welfare, AND the First AmENDMENT}

Without freedom of thought, there can be no such thing as wisdom; and no such thing as publick liberty, without freedom of speech: Which is the right of every man, as far as by it he does not hurt and control the right of another...

$$
\text { - Cato's } \text { Letters }^{24}
$$

In constructing and maintaining a system of freedom of expression, the ... crucial issues have revolved around the question of what limitations, if any, ought to be imposed upon [free expression] in order to reconcile that interest with other individual and social interests sought by the good society.

241 John Trenchard and Thomas Gordon, Cato's Letters No. 15, at 110 (Ronald Hamowy ed., Liberty Fund 1995) (1755) [hereinafter CATO’s LETTERS]. 
— Thomas I. Emerson ${ }^{25}$

Any effort to determine the scope of First Amendment rights must begin with the constitutional text: "Congress shall make no law . . . abridging the freedom of speech, or of the press ...."26 At first glance, this language appears absolute, leaving no room for regulation. Yet on closer examination several questions arise. First, what is meant by "the freedom of speech"? On one hand, the term might be understood in a purely descriptive way, to refer to the absence of external restrictions on speech. On this reading, the Amendment's protection would apply to all acts of speech, regardless of whether they might be considered rightful or wrongful. Alternatively, "freedom of speech" may be taken in a normative sense, to refer to the rightful exercise of the capacity for expression. "Abridging" raises a similar issue: do all regulations of speech abridge its freedom, or only those that are unjustified or illegitimate? Again, what should we make of the fact that the Amendment refers only to Congress? Even if we assume that the Amendment imposes an absolute ban on federal regulation, is the same true when the principle of free speech is applied to the states through the Fourteenth Amendment? Issues of this sort are critical to an understanding of the First Amendment, yet they cannot be resolved by reference to the text alone. Instead, the Amendment's meaning must be understood in relation to our developing conception of freedom of expression and its place within the American legal, political, and social order. ${ }^{27}$

In this Part, I briefly explore how free speech was understood in the early American Republic, and how this conception was transformed in the late nineteenth and the twentieth centuries. This history will shed crucial light on the problem at the core of contemporary disputes over the First Amendment - the apparently irreconcilable conflict between free speech and other values - and will indicate a way to escape from this predicament.

\section{A. The Natural Rights Origins of the First Amendment}

\section{The English Background}

To articulate the basis and scope of liberty of speech and press, eighteenthcentury Americans drew on a variety of sources, including the common law and the civic-republican tradition. ${ }^{28}$ But the most comprehensive framework they looked to was provided by the theory of natural rights and the social contract.

25 Thomas I. Emerson, Toward a General Theory of the First Amendment, 72 YALE L.J. 877, 887 (1963) [hereinafter Emerson, General Theory].

26 U.S. CONST. amend. I.

27 For one of the best contemporary statements of this approach to interpretation, see RoBert C. POST, Theories of Constitutional Interpretation, in CONSTITUTIONAL DomaIns 1 (1995) (arguing that Constitution ultimately should be interpreted in light of evolving ethos of the American community).

28 See infra notes 50-70 and accompanying text (discussing Blackstone's Commentaries); notes 39-49 and accompanying text (discussing Cato's Letters). 
As developed in the works of John Locke, this theory sought to determine the purpose and limits of government by tracing its rise from a state of nature. In that condition, individuals have a right to natural liberty, defined as the power to control one's own person, actions, and possessions without interference by others. ${ }^{29}$ This liberty is not unbounded, however, but is subject to the constraints of the law of nature, which enjoins individuals to respect the freedom, equality, and rights of others. ${ }^{30}$ In the state of nature, natural law has little power to restrain the violation of rights, for it lacks effective means of enforcement. For this reason, individuals agree to form a society for mutual protection. In so doing, they alienate a portion of their natural liberty to the community, which is empowered to regulate individual conduct to the extent necessary to protect rights and promote the common good. ${ }^{31}$

Locke insists, however, that some elements of liberty are inalienable. Although such rights are not subject to legislative regulation for the public good, they are nevertheless limited by the rights of others. ${ }^{32}$ In addition to liberty of conscience, the category of inalienable rights includes freedom of thought in general. ${ }^{33}$ This right is not only inherent in individuals, but lies at the foundation of liberty. According to Locke, human freedom is ultimately grounded in reason-in our capacity as rational beings to determine our own thoughts and actions. ${ }^{34}$ Locke therefore condemns rulers who seek to "enslave[]" their subjects "in that which should be the freest part of Man, their Understandings." 35

As this discussion suggests, Locke's account of freedom of thought has not only an individual but also a political dimension. When individuals enter into the social contract, they give up their natural liberty to judge of and defend their own rights, and transfer this power to the community, to be used for the protection of its members. ${ }^{36}$ Thus all political authority is originally vested in the community. In turn, the community generally entrusts this power to a particular government.

29 See John Locke, Two Treatises of Government, II $\S 4$ (Peter Laslett ed., Cambridge Univ. Press 1988) (1698) [hereinafter Locke, Two TREATiSES].

30 See id. II $\S 6$.

31 See id. II § 123-3.

32 See, e.g., John Locke, A LetTer ConCERning Toleration 47 (James Tully ed., Indianapolis, Hackett Publishing Co. 1983) (William Popple trans., 1st ed., 1689) [hereinafter LOCKE, TOLERATION].

33 As Locke explains, "though Men uniting into politick societies, have resigned up to the publick the disposing of all their Force... : yet they retain still the power of Thinking" as they like. JoHn Locke, An Essay Concerning Human Understanding bk. II, ch. XXVIII, § 10, at 353 (Peter H. Nidditch ed., Clarendon Press 1975) (1700) [hereinafter cited as LOCKE, ESSAY]. In order to establish peace and order in civil society, individuals must give up the unrestricted power to act or to use force whenever they see fit. But it is not necessary for them to give up the power to think for themselves, even if it were possible to do so.

34 See id. bk. II, ch. XXI; Locke, Two Treatises, supra note 29, II § 63.

35 LOCKE, EsSAY, supra note 33, bk. IV, ch. XX, at 708.

36 See Locke, Two Treatises, supra note 29, II $\S \S 87-88,91,127-31$. 
According to Locke, however, the people always retain the right to judge whether the government, as their "Trustee or Deputy," has acted contrary to its trust. ${ }^{37}$ In this way, Locke not only justifies a right to revolution, but implicitly lays the foundation for the eighteenth-century libertarian doctrine of political freedom of speech. $^{38}$

These implications of Lockean thought were developed more fully by later writers, especially the radical Whigs John Trenchard and Thomas Gordon. In Cato's Letters, first published in the 1720s, Trenchard and Gordon defended and popularized Locke's theory of natural rights, the social contract, and the right of revolution. ${ }^{39}$ At the same time, they fused that theory with a strong civic-republican emphasis on the active role of the people in politics. ${ }^{40}$ The rhetorical power of this position is evident in Cato's famous essay on freedom of speech. Relying on the Lockean premise that " $[\mathrm{t}]$ he administration of government is nothing else, but the attendance of the trustees of the people upon the interest and affairs of the people," Cato contended that it was the legitimate business of the people to oversee public affairs and determine whether they were being properly conducted. ${ }^{41}$ Drawing not only on English history but also on classical republican writers such as Livy, Plutarch, and Tacitus, Cato asserted that freedom of speech was "the great bulwark of liberty," protecting the people against tyranny by preventing and exposing abuses of power. ${ }^{42}$

For Cato, the right to "think what you would, and speak what you thought" 43 was not merely a barrier against government oppression; it was also an essential element of natural liberty. "Government," Cato argued, "being intended to protect men from the injuries of one another, and not to direct them in their own affairs, in which no one is interested but themselves; it is plain that their thoughts and domestick concerns are exempted entirely from its jurisdiction." 44 The natural right

37 See id. II $\S \S 149,240$.

38 For further exploration of the Lockean origins of freedom of speech, see Steven J. Heyman, The Liberty of Rational Creatures: Lockean Natural Rights and the Freedom of Speech and Thought (May 1997) (manuscript on file with author).

39 CATO's LetTers, supra note 24. For discussions of Cato's Letters and their influence on the eighteenth-century American conception of freedom of speech, see DAVID S. Bogen, Bulwark of Liberty 16-20, 21 (1984); Leonard W. LeVy, Emergence of A Free Press 109-14 (1985) [hereinafter LeVy, EMERGENCE] (observing that "[i]n the history of political liberty as well as of freedom of speech and press, no eighteenth century work exerted more influence than Cato's Letters").

40 On Cato's fusion of Lockean natural rights and the republican tradition, see Michael P. Zuckert, Natural Rights And the New Republicanism 289-319 (1994).

41 CATO's LetTERS, supra note 24, No. 15, at 111.

$42 I d$. at 114. For a modern restatement of this view, see Vincent Blasi, The Checking Value in First Amendment Theory, 1977 AM. B. Found. RES. J. 521 [hereinafter Blasi, Checking Value].

43 CAto's LetTers, supra note 24, No. 15, at 113 (translating TACitus, Historiae $1.1)$.

44 Id. No. 62, at 428. 
to free speech was limited only by the obligation to respect the rights of others, by "injur[ing] neither the society, nor any of its members." 45 For example, private defamation was wrongful because it violated the individual right to reputation. ${ }^{46}$ But Cato expressed strong reservations about the traditional law of seditious libel, which punished even true statements defamatory of the government or its officials. Although he acknowledged that political libels might occasionally foment causeless discontents among the people, he argued that this harm was outweighed by the benefits of having "some check upon [official] behaviour,... as well as by warning other people to be upon their guard against oppression." 47 The law of libel had to be carefully confined if it was not to become an instrument of tyranny. ${ }^{48}$ In particular, Cato asserted that truthful accusations of public wrongdoing "can never be a libel in the nature of things." 49

The most powerful conservative response to this view came from Sir William Blackstone, whose Commentaries on the Law of England appeared in the late 1760s. Although he conceded that "[t]he liberty of the press is ... essential to the nature of a free state," Blackstone insisted that "this consists in laying no previous restraints upon publications, and not in freedom from censure for criminal matter when published." ${ }^{50}$ Thus the traditional common law, which punished not only private libels but also seditious, blasphemous, and offensive publications, was fully consistent with a free press. ${ }^{51}$

To a modern reader, Blackstone's position appears not merely narrow but almost incomprehensible. How can liberty of the press allow one to publish whatever one chooses, yet afford no protection against subsequent punishment? To understand Blackstone's view, we must briefly explore his political theory. ${ }^{52}$

Following Locke, Blackstone held that "the principal aim of society is to protect individuals in the enjoyment of those absolute rights, which were vested in them by the immutable laws of nature." 53 He identified those rights as life (and, more broadly, personal security), personal liberty, and private property. ${ }^{54}$ A major

45 Id.

46 See id. No. 32, at 231.

472 id. No. 100, at 713-17.

48 Id. at 717.

491 id. No. 32, at 228. The radical Whig ideology of natural rights and opposition to tyranny was also central to the most influential defense of free speech in colonial America. See James Alexander, A Brief Narrative of the Case and Trial of John Peter Zenger (Stanley Nider Katz ed., 2d ed., Harvard Univ. Press 1972) (1736).

504 William Blackstone, Commentaries on the Laws of England *151-52 (St. George Tucker ed., Philadelphia, Young \& Small 1803).

51 See id. at *151-53.

52 For a valuable discussion of Blackstone's political philosophy, see Herbert J. Storing, William Blackstone, in History of Political Philosophy 594 (Leo Strauss \& Joseph Cropsey eds., 2d. ed. 1972).

531 BLACKSTONE, supra note 50 , at $* 124$.

54 See id. at *129-40. 
objective of the Commentaries was to rationalize the English constitution and common law by showing the ways in which they protected these rights. ${ }^{55}$

Yet despite his common ground with Locke and Cato, Blackstone portrayed natural liberty in a less positive light. Although he held that such freedom is "a right inherent in us by birth, and one of the gifts of God to man at his creation," Blackstone also subscribed to the traditional Christian doctrine that human nature has become fallen and corrupt. ${ }^{56}$ Natural liberty was a "wild and savage" condition which was "infinitely [less] desirable" than the "legal obedience and conformity" that characterizes organized society. ${ }^{57}$ For Blackstone, the function of society was not merely to protect natural rights but also to civilize human beings. He therefore emphasized the extent to which natural liberty was alienable, and subject to regulation by laws made by the community for the public good - a good that encompassed not only the rights of individuals, but also social values such as order, morality, and religion. ${ }^{58}$

Blackstone also gave a different account of political authority. Distancing himself from the Lockean doctrine that all power is initially vested in the people, Blackstone stated that, when individuals enter into society, they agreed to submit to the authority of those they regarded as best capable of governing for the public good. ${ }^{59}$ The evidence of this general consent was long-standing tradition. ${ }^{60}$ In England, the legislative authority, which was the supreme power in any state, was vested in a Parliament consisting of the king, the aristocracy, and representatives of the people themselves, while the executive power belonged to the king alone. ${ }^{61}$

In contrast to Locke and Cato, Blackstone stressed the hierarchical relationship between rulers and their subjects. Indeed, the very idea of law was that of a "rule of action, which is prescribed by some superior, and which the inferior is bound to obey."62 A "due subordination of rank" was essential in a well-governed society, so that "the people may know ... such as are set over them, in order to yield them their due respect and obedience." 63

Consistent with the Whig tradition, Blackstone recognized that the king's powers as supreme executive were limited by laws declaring the rights of the people, such as the Magna Carta and Bill of Rights. ${ }^{64}$ Moreover, he defended the English Revolution of 1688, in which the Lords and Commons determined that King

55 See id. at *145.

56 Id. at *125; see id. at *41-42.

57 Id. at $* 125$.

58 See id. at *125 (defining civil liberty as "natural liberty so far restrained by human laws (and no farther) as is necessary and expedient for the general advantage of the public"); $4 \mathrm{id}$. at *152, quoted infra at text accompanying note 69 .

59 See $1 i d$. at $* 48$.

60 See id. at $* 190$ (discussing power of king).

61 See id. at $* 50-51$.

62 Id. at $* 38$

63 Id. at $* 157-58, * 271$.

64 See id. at *127-28,*141. 
James II's attempts to subvert the constitution amounted to an abdication of the throne. ${ }^{65}$ At the same time, however, Blackstone criticized the Lockean theory of revolution, endorsed by "some zealous republicans," which "would have reduced the society almost to a state of nature," leveled all distinctions of property, rank, and authority, overturned all positive laws, and left the people free to establish a new social and political regime. ${ }^{66}$ In short, while Cato's Letters synthesized natural rights theory with civic republicanism, Blackstone fused that theory with the ideology of the traditional legal, political, and social order.

We are now in a better position to understand Blackstone's views on liberty of the press. For Blackstone, freedom of thought and expression were elements of natural liberty. It would be inconsistent with that liberty to compel the press to submit to prior censorship, for that would make the executive "an arbitrary and infallible judge of all controverted points in learning, religion, and government."67 The press "became properly free" in 1694 when Parliament refused to renew the law authorizing such censorship. ${ }^{68}$ The result, however, was merely to place publication on a par with other forms of liberty. For Blackstone, expression was an alienable right which was subject to regulation for the common good. Publications that violated laws against seditious, blasphemous, or immoral writings constituted not liberty but licentiousness. Accordingly, Blackstone argued that to subject such writings to subsequent punishment under the law was "necessary for the preservation of peace and good order, of government and religion, the only solid foundations of civil liberty." 69 This was especially true of libels against public officials; whether true or false, such accusations undermined the respect for authority upon which government depends. ${ }^{70}$

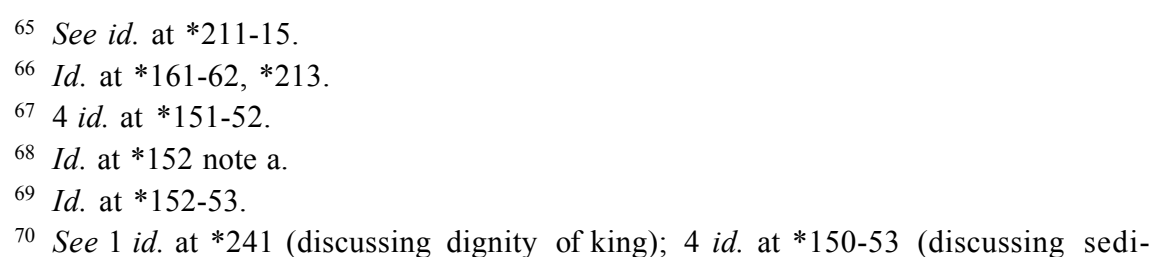
tious libel). Blackstone did acknowledge that some aspects of liberty were beyond the legitimate reach of human laws, including liberty of conscience and freedom of thought, so long as they remained strictly private. See, e.g., $4 \mathrm{id}$. at *45,*49, *51-52 (on religious liberty); $i d$. at $* 152$ (emphasizing that the common law imposes no restraint on private "freedom of thought or inquiry"). More generally, Blackstone maintained that civil government had no business interfering with purely private conduct that did not affect other individuals or the society itself. See $1 \mathrm{id}$. at $* 123-24 ; 4 \mathrm{id}$. at $* 41-42$. Yet his political theory precluded him from treating even these narrowly defined rights as legal limitations on governmental authority. According to that theory, in all governments there must be a body that possesses sovereign authority. Under the English constitution, this "absolute despotic power" was vested in Parliament, whose authority extended even to altering the constitution itself. $1 \mathrm{id}$. at $* 48-49, * 160-61$. For this reason, if Parliament were to pass a law contrary to reason or justice, the judiciary would not be free to reject it, "for that were to set the judicial power above that of the legislature, which would be subversive of all government." Id. at *91. 
2. Natural Rights and the Founding of the American Republics

Although the revolutionary ideology of Locke and the radical Whigs was marginal in eighteenth-century England, it had a profound influence on American political thought. ${ }^{71}$ In addition to providing the justification for the American Revolution, this ideology clearly emerges from the bills of rights affixed to most of the first state constitutions. Thus, the Pennsylvania Declaration of Rights opens with the assertion that "all men are born equally free and independent, and have certain natural, inherent and inalienable rights, amongst which are, the enjoying and defending life and liberty, acquiring, possessing and protecting property, and pursuing and obtaining happiness and safety."72 "[A]11 power," the Declaration continues, is "originally inherent in, and consequently derived from, the people; therefore all officers of the government, whether legislative or executive, are their trustees and servants, and at all times accountable to them." 73 In addition to many other personal rights, the Declaration asserts that "the people have a right to freedom of speech, and of writing, and publishing their sentiments: therefore the freedom of the press ought not to be restrained." 74

In this way Pennsylvania placed liberty of speech and press squarely within the framework of natural rights and popular sovereignty. Similarly, the Virginia Declaration of Rights echoed Cato's Letters in asserting that "the freedom of the Press is one of the greatest bulwarks of liberty, and can never be restrained but by despotick Governments."75 At the same time, Americans agreed with Cato that, as a natural right, free expression was limited by the rights of others, including the right to reputation. For example, while the Massachusetts Declaration provided that the liberty of the press "ought not... to be restrained in the Commonwealth," it also declared that "[e]ach individual in the society has a right to be protected by it," and therefore "ought to find a certain remedy, by having recourse to the laws, for all injuries or wrongs which he may receive in his person, property, or character."76

71 See Bernard Bailyn, The Ideological Origins of the American Revolution 331 51 (enlarged ed., 1992); Gordon S. Wood, The Creation of the American Republic, 1776-1787 (1969). On the impact of radical Whig thought on the early American conception of free speech, see David M. Rabban, The Ahistorical Historian: Leonard Levy on Freedom of Expression in Early American History, 37 Stan. L. REV. 795, 821-36 (1985) [hereinafter Rabban, Ahistorical Historian]. For a valuable discussion of free speech and natural rights in eighteenth-century America, see Philip A. Hamburger, Natural Rights, Natural Law, and American Constitutions, 102 YALE L.J. 907 (1993).

72 Pa. Declaration of Rights of 1776, art. I, in 1 Bernard Schwartz, The Bill of RighTS: A DOCUMENTARY HISTORY 264 (1971).

73 Pa. DeClaration of Rights of 1776, art. IV, in id. at 264-65.

74 Pa. DeClaration of Rights of 1776, art. XII, in id. at 266.

75 VA. DeClaration OF Rights of 1776, art. 12, in id. at 234.

76 Mass. Constitution of 1780, pt. 1, arts. X, XI, XVI (emphasis added), in id. at 34142. This position is also clearly expressed in the writings of Thomas Jefferson. In accord with radical Whig ideology, Jefferson regarded freedom of expression as a natural 
When a new Federal Constitution was proposed in 1787, the most powerful objection leveled against it was that it lacked a bill of rights. ${ }^{77}$ Among the most important of these rights, Antifederalists contended, were freedom of speech and press, which they characterized as inalienable rights of human nature and invaluable bulwarks against tyranny. ${ }^{78}$ In response, Federalists argued that a bill of rights was unnecessary. As James Wilson explained, when the people adopted state constitutions, they "invested their representatives with every right and authority which they did not in explicit terms reserve." 79 Hence bills of rights might be required to protect liberty against invasion by state governments. By contrast, under the Federal Constitution the people retained all rights and powers that they did not positively delegate to the government. In particular, Wilson insisted that Congress had been granted no power to interfere with the liberty of the press. ${ }^{80}$

right, and freedom of the press as a barrier against governmental oppression. See, e.g., Petition to the Virginia House of Delegates (Aug. 1797) (asserting that the people have a "natural right of communicating their sentiments to one another by speaking and writing"), in Freedom of the Press from ZeNGer to JefFerson 349 (Leonard W. Levy ed., 1966) [hereinafter From ZENGER TO JEFFERSON]; Letter from Thomas Jefferson to Noah Webster (Dec. 4, 1790) (characterizing freedom of the press as among the "fences which experience has proved peculiarly efficacious against wrong"), in id. at 342 . In his various efforts to draft constitutional protections for these rights, however, Jefferson consistently indicated that they did not extend to false statements injurious to others. See, e.g., Draft Constitution for Virginia art. IV (June 1776) ("Printing presses shall be free, except so far as by commission of private injury cause may be given for private action."), in Thomas Jefferson, Writings 344 (Merrill D. Peterson ed., Library of America 1984); Letter from Thomas Jefferson to Rabout de St. Etienne (June 3, 1789) (enclosing draft charter of rights for France containing similar provision), in id. at 956; Letter from Thomas Jefferson to James Madison (Aug. 28, 1789) (proposing that James Madison's draft of the First Amendment, see infra text accompanying note 90, be amended to read: "The people shall not be deprived or abridged of their right to speak to write or otherwise to publish any thing but false facts affecting injuriously the life, liberty, property, or reputation of others or affecting the peace of the confederacy with foreign nations."), in FrOM ZENGER TO JEFFERSON, supra, at 340. For a persuasive demonstration that eighteenthcentury Americans regarded free speech as limited by the rights of others, see Hamburger, supra note 71 , at $920 \&$ n.41, 928, 936 \& n.83, 948-53.

77 On the adoption of the Bill of Rights, see Robert A. Rutland, The BirTh of THE BiLl OF Rights, 1776-1791 (1955).

78 See, e.g., Letters of Centinel No. 2, in 2 The Complete Anti-Federalist 143-44 (Herbert J. Storing ed., 1981); Letters from the Federal FArmer Nos. 2, 6, in id. at 231-32, 262; Speech of Patrick Henry in Virginia Ratifying Convention, in 3 THE Debates in the Several State Conventions on the Adoption of the Federal CONSTITUTION 449 (Jonathan Elliot ed., 2d ed. 1836) [hereinafter ElLiot's Debates].

79 James Wilson, Speech at a Public Meeting in Philadelphia (Oct. 6, 1787), in 1 THE Debate on the Constitution 64 (Bernard Bailyn ed., Library of America 1993).

${ }^{80} \mathrm{Id}$. Wilson added that to have included a declaration of the liberty of the press in the Constitution would have been not merely useless but dangerous, because it "might have been construed to imply that some degree of power was given, since we undertook 
Yet arguments of this sort were unable to overcome the desire for a bill of rights. ${ }^{81}$ Several state conventions accompanied their ratifications with recommended amendments, ${ }^{82}$ or declined to ratify in the absence of such amendments. ${ }^{83}$ The proposed amendments were derived largely from the state declarations of rights and reflected their radical Whig principles. The first state proposal relating to freedom of expression, which came from the Virginia convention, read: "That the people have a right to freedom of speech, and of writing and publishing their sentiments; that the freedom of the press is one of the greatest bulwarks of liberty, and ought not to be violated." 84 This recommendation, which was to form the basis for James Madison's draft of the First Amendment, combined the Pennsylvania Declaration's focus on free speech as a natural right of individuals with the Virginia Declaration's Catonic description of liberty of the press as a safeguard against abuse of power. ${ }^{85}$

In June 1789, Madison introduced his proposal for a bill of rights in the First Congress. In an important speech, he explained that the purpose of such a document was "to limit and qualify the powers of Government, by excepting out of the grant of power those cases in which the Government ought not to act, or to act only in a particular mode." 86 Such limitations, he implied, were subject to judi-

to define its extent." Id. For similar arguments, see The FedERALIST No. 84 (Alexander Hamilton).

81 See Wood, supra note 71, at 542.

82 See, e.g., New York Ratifying Convention, in 2 SchwarTz, supra note 72, at 91118; Virginia Ratifying Convention, in 3 Elliot's DeBATES, supra note 78, at 657-61.

${ }^{83}$ See North Carolina Ratifying Convention, in 4 Elliot's DeBATES, supra note 78, at 242-47. In other states, the Antifederalist minority proposed amendments which were rejected by the Convention, but which were influential in the subsequent debate. See, e.g., The Address and Reasons of Dissent of the Minority of the Convention of Pennsylvania to Their Constituents (Dec. 18, 1787), in 3 ThE Complete ANTIFEDERALIST, supra note 78, at 145, 150-52.

${ }^{84}$ Virginia Ratifying Convention, Proposed Bill of Rights, art. 16th, in 3 ELLIOT'S DEBATES, supra note 78 , at 659.

85 It is also clear that these freedoms were regarded as bounded by the rights of others, at least that of reputation, for the amendments included a provision that "every freeman ought to find a certain remedy, by recourse to the laws, for all injuries and wrongs he may receive in his person, property, or character." Virginia Ratifying Convention, Proposed Bill of Rights, art. 12th, in id. at 658; see Hamburger, supra note 71, at 950-51. North Carolina called for identical amendments before it would ratify the Constitution. See North Carolina Ratifying Convention, Proposed Declaration of Rights, arts. 12th, 16th, in 4 ELLIOT's DEBATES, supra note 78, at 244. For other state proposals on freedom of speech and press, see THE COMPLETE BILL OF Rights 92-93 (Neil H. Cogan ed., 1997).

86 James Madison, Speech to House of Representatives (June 8, 1789), in CREATING the Bill of Rights: The Documentary Record from the First Federal Congress 81 (Helen E. Veit et al. eds., 1991) [hereinafter Madison Speech]. 
cial enforcement. ${ }^{87}$ Madison identified two categories of rights that were protected in bills of rights: (1) natural rights, or "those . . . which are retained when particular powers are given up to be exercised by the legislature"; and (2) "positive rights" such as trial by jury, which were equally "essential to secure the liberty of the people." 88 Madison's notes cite freedom of speech as a paradigmatic instance of a natural right. ${ }^{89}$ Following the proposal of the Virginia Convention, Madison's draft of the First Amendment provided: "The people shall not be deprived or abridged of their right to speak, to write, or to publish their sentiments; and the freedom of the press, as one of the great bulwarks of liberty, shall be inviolable." 90 Although sparse, the legislative history of the Amendment also contains other indications that it was understood in the context of natural rights. ${ }^{91}$

In his groundbreaking study of the origins of the First Amendment, Leonard Levy argued that the Amendment reflected Blackstone's narrow conception of liberty of the press as a mere ban on prior restraints rather than subsequent punishment. ${ }^{92}$ A basic flaw in this argument was the assumption that anyone who believed that expression could be subjected to subsequent punishment must have shared Blackstone's position. ${ }^{93}$ As we have seen, however, virtually everyone in the eighteenth century, from Blackstonian conservatives to libertarians like Cato and Jefferson, held that free expression, like other forms of liberty, was bounded by law. But whereas conservatives regarded expression as an ordinary liberty that was

87 See id. at 83-84.

$88 \mathrm{Id}$. at 81.

89 James Madison, Notes for Amendments Speech (1789), in 2 SchWARTZ, supra note 72 , at 1042 .

90 Madison Resolution (June 8, 1789), in CREATING THE BILL OF RighTS, supra note 86, at 12 [hereinafter Madison Resolution].

91 This point emerges with great clarity in the draft of the bill of rights prepared by Representative Roger Sherman of Connecticut, a member of the House committee on the subject. One section of Sherman's draft read:

The people have certain natural rights which are retained by them when they enter into society, [sic] Such are the rights of conscience in matters of religion; of acquiring property, and of pursuing happiness and safety; of Speaking, writing and publishing their Sentiments with decency and freedom; of peaceably Assembling to consult their common good, and of applying to Government by petition or remonstrance for redress of grievances. Of these rights therefore they Shall not be deprived by the government of the united States.

Roger Sherman's Proposed Committee Report (July 21-28, 1789), in id. at 266; see also id. at 154, 159 (remarks of Rep. Sedgwick in House debate on First Amendment) (observing that the right of the people to assemble in order to "freely converse together" is "a self-evident unalienable right")

92 Leonard W. Levy, Legacy of Suppression: Freedom of Speech and Press in EARLy AMERICAN History (1960) [hereinafter LEVy, LEGACY].

93 For a striking illustration of this point, see LEVY, EMERGENCE, supra note 39, at 251 (characterizing Jefferson's views on freedom of the press, see supra note 76, as "pure Blackstone"). 
subject to plenary regulation for the public good, libertarians inclined to view it as an inalienable right that was limited only by the rights of others.

It is certainly true that, at the time the Constitution and Bill of Rights were adopted, some Americans described freedom of the press in Blackstonian terms. ${ }^{94}$ In part, as Levy observes, this reflected the persistence of "the taught traditions of [the] law," of which Blackstone was the foremost expositor. ${ }^{95}$ There were also political reasons for invoking Blackstone. As Gordon Wood has shown, the movement for a stronger federal constitution drew much of its support from conservatives who believed that, under the post-Revolutionary state governments, America suffered from an excess of popular liberty and democracy. ${ }^{96}$ For such conservatives, Blackstone's insistence that the liberty of the press did not prevent regulation of its "licentiousness" was quite appealing. More generally, this concern about excessive liberty may help to explain the Federalists' resistance to a bill of rights.

Yet if the Constitution was partly motivated by conservative concerns, the demand for a bill of rights represented a reassertion of the radical Whig ideology that animated the Revolution. ${ }^{97}$ For this reason it is a mistake to regard Blackstone as the key to the original meaning of the First Amendment. As we have seen, Blackstone's approach rested on the view that freedom of expression was an aspect of natural liberty that was alienable and subject to legislative regulation for the common good. By contrast, the object of the Bill of Rights was to specify those freedoms that Americans regarded as essential or inalienable, and to reserve them from government control. Freedom of speech and press fell in this category, not only as inherent rights of individuals but also as indispensable means by which the people could hold public officials to account - a view that was contrary to Blackstone's position that the government, not the people, was sovereign. ${ }^{98}$ In these respects, Blackstone's view was fundamentally inconsistent with the logic and purpose of the First Amendment.

94 See, e.g., 2 Elliot's Debates, supra note 78, at 449-50 (remarks of James Wilson in Pennsylvania Ratifying Convention) ("What is meant by the liberty of the press is, that there should be no antecedent restraint upon it; but that every author is responsible when he attacks the security or welfare of the government, or the safety, character, and property of the individual.").

95 LEVy, LeGACY, supra note 92, at 237.

96 See Wood, supra note 71, 393-518.

97 See Bernard Bailyn, Fulfillment: A Commentary on the Constitution, in BAILYN, supra note 71 , at 331-51.

98 See supra notes 59-66 and accompanying text; supra note 70. For persuasive criticism of Levy on this ground, see Rabban, Ahistorical Historian, supra note 71, at 821-54. In his later work, Levy partially retreats from the argument of Legacy of Suppression. See LEVY, EMERGENCE, supra note 39, at vii-xix. In particular, he acknowledges that, for eighteenth-century Americans, "freedom of the press meant more than just freedom from prior restraint," and that it included "the right to criticize the government, its officers, and its policies as well as to comment on any matters of public concern." Id. at 272 . 
These points were central to the controversy over the Sedition Act, enacted in 1798 to insulate the Federalist administration of John Adams from criticism by the Republican supporters of Thomas Jefferson. The Act made it a crime to publish "any false, scandalous and malicious writing" against the government, Congress, or President of the United States, "with intent to defame [them] or to bring them . . . into contempt or disrepute; or to excite against them . . . the hatred of the good people of the United States." 99 In concessions to libertarian doctrine, the Act made truth a defense and provided that the jury should have power to determine both law and fact. ${ }^{100}$

Nevertheless, the Act was soon denounced as unconstitutional by the Republican-dominated legislatures of Kentucky and Virginia. In a report on behalf of the Virginia Resolutions, James Madison set forth the Republican case. The Federalists, he observed, defended the Act on the ground that the First Amendment reflected the Blackstonian view. ${ }^{101}$ But "this idea of the freedom of the press can never be admitted to be the American idea of it," since it "would seem a mockery to say that no laws should be passed preventing publications from being made, but that laws might be passed punishing them in case they should be made."102 Madison then traced the difference between the two conceptions to the "essential difference between the British Government and the American Constitutions."103 In Great Britain, the protections of the Magna Carta and Bill of Rights were aimed only at the king, while the people's representatives in the legislature were regarded as unlimited in their power and "sufficient guardians of the rights of their constituents."104 "Under such a government as this," Madison reasoned, "an exemption of the press from previous restraint, by licensors appointed by the king, is all the freedom that can be secured to it."105 In America, by contrast, the people's rights were secured not merely by laws but by constitutions, and were protected against

991 Stat. 596, § 2 (1798).

100 See id. $\S 3$.

101 See, e.g., John Marshall, Report of the Minority on the Virginia Resolutions (Jan. 22,1799 ) (defining liberty of the press as "a liberty to publish, free from previous restraint, any thing and every thing at the discretion of the printer only, but not the liberty of spreading with impunity false and scandalous slanders which may destroy the peace and mangle the reputation of an individual or of a community"), reprinted in 5 The Founders' Constitution 136, 138 (Philip B. Kurland \& Ralph Lerner eds., 1987); House Select Committee, Report on Petitions for Repeal of Alien and Sedition LAws, in 9 ANNALS OF CONG. 2986, 2988 (1799) (asserting that the liberty of the press consists in "a permission to publish, without previous restraint, whatever [one] may think proper, being answerable to the public and individuals, for any abuse of this permission to their prejudice").

102 James Madison, Report on the Virginia Resolutions (Jan. 1800), reprinted in 5 The Founders' Constitution, supra note 101, at 141, 142 [hereinafter Madison, Report].
103 Id.
104 Id.
105 Id. 
violation by the legislature as well as the executive. It followed that in America the liberty of the press was protected not merely against prior restraint by executive officials, but also against subsequent punishment under legislative enactments. ${ }^{106}$

Madison proceeded to address the Federalist claim that, even if this liberty extended beyond protection against prior restraints, its substantive scope must be determined by reference to the English common law. Once more, he argued that the different nature of the two governments required a broader view. In the United States, unlike Great Britain, the people had a right to elect both the legislature and the executive. In order to exercise this right, which constituted "the essence of free and responsible government," the people must be free to discuss the relative merits and demerits of candidates. ${ }^{107}$ Moreover, in such a government the people retained the right to judge whether public officials had properly discharged their trust. Employing the rhetoric of the radical Whig tradition, Madison asserted that, to the extent that officials failed to do so, "it is natural and proper, that ... they should be brought into contempt or disrepute, and incur the hatred of the people." 108

In opposing the Sedition Act, the Republicans relied not only on freedom of expression, but also on notions of federalism. In Madison's words, they contended that the First Amendment "was meant as a positive denial to Congress of any power whatever" over the press, leaving any legitimate authority over it to the states. ${ }^{109}$ This position, which reflected the Republicans' strict constructionist approach to constitutional interpretation, ${ }^{110}$ had less clear support in the history and logic of the First Amendment. It is true, as Madison emphasized, that during the ratification debate the Constitution's supporters had responded to Antifederalist objections by insisting that it gave Congress no power over the press or other essential rights. Yet this argument had proved unconvincing. The intent of the First Amendment may have been (as Madison argued in 1800) to "explicitly declare that no such power was delegated" to the federal government, ${ }^{111}$ but it may equally have been to ensure that, if any of Congress' powers could affect the press, they would be limited by the same principles that applied to state governments under their own declarations of rights. Indeed, Madison's own actions in 1789 are

106 See id.

107 Id. at 145.

108 Id. at 144 .

109 Id. at 143-44.

110 For leading statements of this approach, see 2 ANNALs OF CoNG. 1944-52 (1791) (speech of Rep. James Madison in opposition to proposal to create national bank); Kentucky Resolutions (1798), in 4 ElLIOT's DeBATES, supra note 78, at 540-44 (attacking constitutionality of Alien and Sedition Acts).

111 Id. at 144. For contemporary defenses of this position, see AKHIL REED AMAR, THE Bill of Rights 20-32 (1998); William T. Mayton, Seditious Libel and the Lost Guarantee of a Freedom of Expression, 84 CoLuM. L. REV. 91 (1984). 
more consistent with the latter than the former interpretation. ${ }^{112}$ This strongly suggests that, when the First Amendment was adopted, there was no clear understanding that it would impose greater restrictions on the federal government than corresponding provisions imposed on the states.

Although Republicans denied all federal power over the press, they did not regard the freedoms of speech and press themselves as absolute. Some accepted the law of seditious libel, as modified by the defense of truth, while others repudiated that law. ${ }^{113}$ Virtually all Republicans, however, believed that freedom of expression was limited by the rights of other individuals, especially the right to reputation. ${ }^{14}$ But Republicans insisted that the protection of those rights belonged to

112 As we have noted, Madison's draft of the First Amendment was indirectly drawn from state constitutional models. See supra notes 84-85, 90, and accompanying text. More generally, his speech stressed the parallels between the proposed federal bill of rights and its state counterparts. See Madison Speech, supra note 86, at 80-83. Madison's proposed bill of rights also contained an amendment that would have provided, in similar language, that "[n]o state shall violate the equal rights of conscience, or the freedom of the press," Madison Resolution, supra note 90, at 13, on the ground that "it is proper that every government should be disarmed of powers which trench upon those particular rights," Madison Speech, supra note 86, at 85. Madison added that, while some states already protected those rights in their own constitutions, others did not, and that no harm would be done by providing "a double security on those points." Id. This evidence seems to indicate that Madison regarded his draft of the First Amendment as imposing the same limits on the federal government that state provisions imposed on the states.

113 Compare, e.g., Letter from Thomas Jefferson to Abigail Adams (Sept. 11, 1804) (reaffirming the power of states to restrain "the overwhelming torrent of slander, which is confounding all vice and virtue, all truth \& falsehood, in the U.S."), in FrOM ZENGER TO JEFFERSON, supra note 76, at 367, with Minority Report on Repeal of Sedition Act, AnNALs OF Cong., 5th Cong., 3d Sess., at 3003-14 (1799) (arguing that the doctrine of seditious libel is "obsolete" and "inconsistent with the nature of our Government"), reprinted in id. at 176-86.

114 For example, St. George Tucker, a leading Republican jurist, described the nature and limits of free expression as follows:

Liberty of speech and of discussion in all speculative matters, consists in the abso-

lute and uncontrollable right of speaking, writing, and publishing, our opinions concerning any subject, whether religious, philosophical, or political; and of inquiring into and, examining the nature of truth, whether moral or metaphysical; the expediency or inexpediency of all public measures, with their tendency and probable effect; the conduct of public men, and generally every other subject, without restraint, except as to the injury of any other individual, in his person, property, or good name.

St. George Tucker, Of the Right of Conscience; and of the Freedom of Speech and of the Press, in 1 Blackstone, supra note 50, app., note G, at 11. Similarly, George Hay, a Republican lawyer and member of the Virginia House of Delegates, contended that liberty of the press consisted of the "absolute freedom" to publish whatever one pleases, "provided he does no injury to any other individual" through "slander and defamation.” Hortensius [George Hay], An Essay on the Liberty of the Press 23 (1799, 2d 
the states rather than the federal government. In Madison's words, individuals were required to seek "a remedy for their injured reputations, under the same laws, and in the same tribunals, which protect their lives, their liberties, and their properties." 115

In this section, I have suggested that the First Amendment reflected the libertarian tradition of the radical Whigs more than the conservatism of Blackstone. As the Sedition Act controversy shows, however, both views found considerable support in late eighteenth-century America, and the debate between them continued for some time to come. ${ }^{16}$ As with other constitutional provisions, this makes it difficult to attribute any precise original meaning to the First Amendment. ${ }^{117}$ Nevertheless, this review of the history may enable us to identify not only sharp disagreements, but also a substantial area of consensus. In the late eighteenth century, Americans generally believed that freedom of thought, belief, and expression were among the natural rights of individuals. These freedoms were also regarded as inherent in republican citizenship, allowing the people to express their views on public affairs and to guard their liberties against governmental encroachment-a right which extended at least to making true allegations against public officials, as even the Sedition Act recognized. At the same time, there was broad agreement that, as natural rights, freedom of speech and press were limited by the rights of others. ${ }^{118}$

\section{B. Free Speech, Natural Rights, and the Fourteenth Amendment}

As originally adopted, the Bill of Rights applied solely to the federal government. ${ }^{119}$ Only after the adoption of the Fourteenth Amendment did the fundamen-

printing 1803), in George Hay, Two Essays on the Liberty of the Press (Da Capo Press 1970).

115 Madison, Report, supra note 102, at 144.

116 Compare, e.g., Tucker, supra note 114 (expressing strong libertarian view of freedom of speech and press) with 3 JOSEPH STORY, COMMENTARIES ON THE CONSTITUTION $\S \S$ 1878-83 (Boston, Hilliard, Gray, \& Co. 1833) (criticizing Tucker and defending Blackstonian view).

117 See LEVy, EMERGENCE, supra note 39, at 268 (observing that "[w]hether the Framers themselves knew what they had in mind is uncertain").

118 This last point is reflected in the Pennsylvania Constitution of 1790, which declared that "[t]he free communication of thoughts and opinions is one of the invaluable rights of man; and every citizen may freely speak, write and print on any subject, being responsible for the abuse of that liberty." PA. CONST. of 1790, art. IX, § VII, reprinted in The COMPLETE BiLl of Rights, supra note 85 , at 95 . This language, which was copied in many other state constitutions, was susceptible of being read in either libertarian or conservative terms. On the latter interpretation, expression was subject to regulation for the public good; on both views, however, it was limited by the rights of others, particularly that of reputation.

119 See Barron v. Baltimore, 32 U.S. (7 Pet.) 243 (1833). Madison's draft of the Bill of Rights included a provision that would have prohibited the states from infringing religious liberty, freedom of the press, or trial by jury. See supra note 112. Although this amendment was adopted by the House, it was rejected in the Senate. 
tal rights of individuals gain the protection of the Federal Constitution against state abridgment. ${ }^{120}$ The history of this Amendment sheds further light on the developing American conception of free expression.

The ideological origins of the Fourteenth Amendment lay in the antislavery movement that gathered force in the decades before the Civil War. ${ }^{121}$ The opponents of slavery denounced it as a violation of the natural rights proclaimed in the Declaration of Independence. Beginning in the $1830 \mathrm{~s}$, antislavery agitation encountered a wave of repression, through mob violence as well as official censorship. ${ }^{122}$ In response, antislavery activists strongly defended freedom of expression, which they described as an inalienable right protected by the American constitutions. ${ }^{123}$ Following the natural rights tradition, Antislavery figures acknowledged that this freedom did not authorize violations of the rights of others. ${ }^{124}$ They in-

120 See, e.g., Laurence H. Tribe, American Constitutional Law $\S 11-2$ (2d ed. 1988) (describing the Supreme Court's incorporation into the Fourteenth Amendment of fundamental rights protected against the federal government by the Bill of Rights).

121 See generally Eric Foner, Free Soll, Free Labor, Free Men: The Ideology of the Republican Party (1970); Jacobus tenBroek, EQual Under LaW (rev. ed. 1965); William M. WieceK, The Sources of Antislavery Constitutionalism in America, 1760-1848 (1977); Daniel A. Farber \& John E. Muench, The Ideological Origins of the Fourteenth Amendment, 1 Const. COMM. 235 (1984).

122 See generally Russell B. Nye, Fettered FreEdom: Civil Liberties AND the SLAVERY CONTROVERSY, 1830-60 (1963). Some of the best recent work on free speech in the ante-bellum era has been done by Michael Kent Curtis. See Michael Kent Curtis, The 1837 Killing of Elijah Lovejoy by An Anti-Abolition Mob: Free Speech, Mobs, Republican Government, and the Privileges of American Citizens, 44 UCLA L. REV. 1109 (1997) [hereinafter Curtis, Lovejoy]; Michael Kent Curtis, The Curious History of Attempts to Suppress Antislavery Speech, Press, and Petition in 1835-37, 89 Nw. U.L. Rev. 785 (1995) [hereinafter Curtis, Curious History]; Michael Kent Curtis, The 1859 Crisis over Hinton Helper's Book, The Impending Crisis: Free Speech, Slavery, and Some Light on the Meaning of the First Section of the Fourteenth Amendment, 68 CHI.-KENT L. REV. 1113 (1993).

123 See, e.g., Dwight L. Dumond, Antislavery 230-33 (1961); Curtis, Curious History, supra note 122, at 859-63.

124 See, e.g., Joseph C. Lovejoy \& Owen Lovejoy, Memoir of the Rev. Elijah Lovejoy 279-80 (New York, J.S. Taylor 1838) (quoting speech of abolitionist Elijah Lovejoy to people of Alton, Illinois, demanding to be protected in God-given and constitutional right to free expression, but acknowledging that this right was properly limited by laws protecting reputation of others), quoted in TENBROEK, supra note 121, at 38 n.6. This position was expressed most clearly by James G. Birney, a leading abolitionist. Some rights, Birney wrote,

are inherent in man, as a moral, intelligent, and active being. They do not originate in constitutions, nor are they conferred by them.... Of these no human power can properly divest [man,] whilst he exercises them so as not to disturb the equally important, and, of course, the equally to be respected rights of others. Among the rights thus conferred is that of publishing opinions. Printing, writing, and speaking, are but modes of exercising it. These rights, in dignity, are altogether superior to such as grow out of the positive enactments of human legislation. ... 
sisted, however, that discussions of the morality of institutions like slavery did not fall in this category. ${ }^{125}$

The antislavery Republican Party came to power in the national elections of 1860. After the Civil War, the Republicans secured the adoption of two constitutional amendments that were intended to more effectually protect natural rights: the Thirteenth, which abolished slavery, and the Fourteenth, which barred the states from abridging the fundamental rights of American citizenship. ${ }^{126}$ It has been forcefully, and in my view convincingly, argued these rights were understood to include the protections enumerated in the Bill of Rights. ${ }^{127}$ In particular, Republicans expressed strong concern for protecting the freedoms of speech and press, which they characterized as natural rights and rights of citizenship, and which they stressed had repeatedly been violated by the southern states before, during, and after the war. ${ }^{128}$

Notwithstanding the sacredness of these rights, they are subjected to this limitation - that they be not exercised, so as to impair the equally precious rights of others. A right pushed to this extremity is no longer a right-it becomes a wrong .... As a wrong, it is to be restrained by adequate penalties. ... [For instance, if,] in the exercise of your right, you forget its proper limits, using against me false and slanderous words, which, if true, would deprive me of the rights I now enjoy, you commit a wrong, for which all equitable laws will compel you, as far as practicable, to make reparation.

The Cincinnati Preamble and Resolutions, No. 2, The Philanthropist, Feb. 26, 1836, at 2 (paragraphing altered) [hereinafter PHILANTHROPIST]. Even when speech was wrongful, Birney added, "the liberty of the press and of speech" required that the wrong "be prevented, precisely as other wrongs in society are prevented"-not by "previous restraint," which "amounts to a censorship destructive of the right," but by "punishment for its abuse." Id. I am grateful to Professor Curtis for providing me with a copy of this article.

125 See Curtis, Lovejoy, supra note 122, at 1177 . For example, in response to the assertion that abolitionist speech should be suppressed because it "injure[d] the acknowledged rights of others" to hold slaves, PHILANThropist, supra note 124 (quoting resolution adopted by Cincinnati anti-abolition meeting), Birney denied that slaveholding was a right-since it was contrary to "the truth... that all men are created equal"-or that efforts to persuade slaveholders of its wrongfulness injured any such right. Id. For a somewhat different view of the abolitionist position, see Curtis, Lovejoy, supra note 122 , at 1177 \& n.275 (suggesting that the notion that free speech was limited by the rights of others was characteristic of proslavery but not antislavery discourse).

126 U.S. CONST. amends. XIII, XIV.

127 See Amar, supra note 111, 163-214; Michael Kent Curtis, No State Shall Abridge: The Fourteenth Amendment And the Bill of Rights (1986). For the contrary view, see Raoul Berger, The Fourteenth Amendment and the Bill of Rights (1989); Charles Fairman, Does the Fourteenth Amendment Incorporate the Bill of Rights?, 2 STAN. L. REV. 5 (1949).

128 See, e.g., CuRTIS, supra note 127, at 49-54. The Republicans' discussion of freedom of speech and press during the debates surrounding the Thirteenth and Fourteenth Amendments were confined to general terms and shed little light on the scope of these 
[Vol. 78:1275

\section{The Transformation of Free Speech Theory}

Thus the natural rights background of the First and Fourteenth Amendments suggests a rather straightforward principle: that free speech is limited by the fundamental rights of others, and that the law may protect these rights against speech that violates them. Although this principle was widely held when those Amendments were adopted, it no longer holds a central place in American constitutional theory or doctrine. Instead, we generally view First Amendment issues in terms of an opposition between freedom of speech and state interests.

To understand this shift, we must explore the transformation of American jurisprudence after the Civil War. During the late nineteenth and early twentieth centuries, the theory of natural rights gave way to a more positivist and utilitarian conception of law. On this view the function of law was not to protect the inherent rights of individuals, but to promote the social good as defined by the community or the state.

One of the leading figures in this development was Oliver Wendell Holmes, Jr. ${ }^{129}$ Although Holmes "enlisted in the Civil War 'as a convinced abolitionist," his experience of its bloodshed and upheaval led him to regard natural rights doctrines as a threat to social order — an attitude that "he shared with much of late-

freedoms. There is other evidence, however, that they accepted the principle, which was inherent in the natural rights tradition and generally accepted at the time, that these freedoms were limited by the rights of others. See, e.g., Cong. Globe, 36th Cong., $1 \mathrm{st}$ Sess. 64 (1859-60) (remarks of Sen. Wilson) (implying that direct incitement and threats are not protected by principle of free speech); id., app. at 205 (remarks of Rep. Lovejoy) (suggesting that right of free speech must be exercised in "peaceful," "orderly and legal way"). Mid-nineteenth-century works on constitutional law expressed the same view. See, e.g., NAthaniel Chipman, Principles of Government: A Treatise on Free Institutions InCluding the CONSTITUTiON OF tHE United States 103-06 (Burlington, Edward Smith 1833) (observing that the right of free speech is limited only by the condition that an individual "violate not the rights of others, or injure the community, of which he is a member"); Thomas M. CoOley, A Treatise on the Constitutional Limitations Which Rest UPON the Legislative Power of the States of the American UNION 422 (Boston, Little, Brown, \& Co. 1868) (noting that "the constitutional liberty of speech and of press" does not protect false and malicious publications that "injuriously affect the private character of individuals"); WILLIAM RAWLE, A VIEW OF THE Constitution of the United States of America 123-24 (2d ed., Philadelphia, Philip H. Nicklin 1829) (asserting that remedies for the abuse of liberty of speech and press "will always be found while the protection of individual rights and the reasonable safeguards of society itself form parts of the principles of our government"); 3 STORY, supra note 116, § 1874 (interpreting First Amendment to mean "that every man shall have a right to speak, write, and print his opinions upon any subject whatsoever, without any prior restraint, so always, that he does not injure any other person in his rights, person, property, or reputation; and so always, that he does not thereby disturb the public peace, or attempt to subvert the government").

129 For valuable discussions of Holmes and legal positivism, see MORTON J. Horwitz, The Transformation of AMERICAN LAW, 1870-1960, at 139-42 (1992); Mark deWolfe Howe, The Positivism of Mr. Justice Holmes, 64 HARv. L. Rev. 529 (1951). 
nineteenth-century American culture."130 In his jurisprudential writings, Holmes rejected Lockean and Kantian notions of the inherent freedom and dignity of individuals. ${ }^{131}$ In particular, he insisted that legal and constitutional interpretation should be divorced from ideas of "the rights of man in a moral sense." 132 Rights had no independent existence, but derived their force from positive law, which aimed to promote social ends. ${ }^{133}$ At bottom, legal disputes involved clashes of social interests, which could be resolved only by "weighing considerations of social advantage." 134

This interest-oriented approach to law was developed more fully in the sociological jurisprudence of Roscoe Pound, a professor and later dean at Harvard Law School. ${ }^{135}$ Like Holmes, Pound rejected traditional natural rights theory and held instead that, "[a]s social institutions, state and law exist for social ends."136 The legal system promoted these ends partly by recognizing certain individual interests, which thereby gained the status of legal rights. Pound insisted, however, that such interests were not entitled to protection for their own sake, but only as means to "the general happiness or the common good."137 For example, while the law's first concern was to prevent violence, it did so not in order to protect "the so-called natural rights of physical integrity and of personal liberty," but rather to secure "the social interest in preserving the peace." 138

According to Pound, law is concerned not only with individual interests but also with "public interests," which he defined as "the interests of the state as a ju-

130 HoRwitz, supra note 129, at 116 (quoting Saul Touster, In Search of Holmes from Within, 18 VAND. L. REV. 437, 449 (1965)).

131 See, e.g., Oliver Wendell Holmes, The Common Law 37-38 (Mark deWolfe Howe ed., Harvard Univ. Press 1963) (1881) [hereinafter Holmes, Common Law]; Oliver Wendell Holmes, Ideals and Doubts, 10 ILL. L. ReV. (now Nw. U.L. Rev.) 1 (1915); Letter from Oliver Wendell Holmes to John C.H. Wu (Aug. 26, 1926), in THE Mind And Faith of Justice Holmes 431-32 (Max Lerner ed., Modern Library ed. 1954). Consistent with his repudiation of natural rights theory, Holmes also rejected efforts to identify the bounds of liberty by reference to the rights of others. See Oliver Wendell Holmes, The Path of the Law, 10 Harv. L. REv. 457, 466 (1897) [hereinafter Holmes, Path of the Law] (criticizing "Mr. Herbert Spencer's Every man has a right to do as he wills, provided he interferes not with a like right on the part of his neighbors").

132 Holmes, Path of the Law, supra note 131, at 460.

133 See id. at 457-61, 469, 474.

134 Id. at 466-67, 474.

135 On Pound, sociological jurisprudence, and freedom of speech, see MARK A. Graber, Transforming Free Speech: The Ambiguous Legacy of Civil Libertarianism 69-74 (1991); David M. Rabban, Free Speech in Progressive Social Thought, 74 TEX. L. REV. 951, 988-1001 (1996) [hereinafter Rabban, Progressive Social Thought]. Pound's views on freedom of speech are expressed most fully in Roscoe Pound, Interests of Personality (pts. 1 \& 2), 28 HARv. L. REV. 343, 445 (1915).

136 Pound, supra note 135, at 347.

137 Id. at 346, 347 (quoting John Dewey \& James H. Tufts, Ethics 482-83 (1908)).

$138 I d$. at $355,357$. 
ristic person," and with "social interests," or "the interests of the community at large."139 As a pragmatist, he believed that human interests ought to be satisfied as far as possible. Because interests conflict with one another, however, they could not all be fulfilled. The legal system must therefore weigh and balance competing interests to determine how far each should be secured. ${ }^{140}$ Because it is a social institution, however, law is ultimately concerned only with social interests. Strictly speaking, then, the law does not take account of individual interests as such, but rather "the social interest in securing the individual interest." 41

In criticizing individual-rights theories and emphasizing the social purposes of law, Holmes and Pound articulated themes that were to become central to early twentieth-century Progressive thought. ${ }^{142}$ In this way, their views played an important role in the legal and constitutional revolution that culminated in the New Deal.

Although the Progressive critique of rights was directed primarily against the extreme defense of property symbolized by Lochner v. New York, ${ }^{143}$ that critique also had implications for the status of civil liberties. ${ }^{144}$ In particular, Holmesian positivism and sociological jurisprudence had the effect of undermining the traditional American rationale for freedom of expression. Rather than a right of nature or republican citizenship, free speech on this view represented merely one interest to be weighed against others. ${ }^{145}$ There was nothing distinctive about expression that entitled it to special protection, or that placed it beyond the authority of the state to regulate like any other form of activity.

This perspective is evident in Schenck v. United States, ${ }^{146}$ the Supreme Court's first important effort to address the meaning of the First Amendment. Writing for a unanimous Court, Justice Holmes upheld the convictions of Socialist Party members for conspiring to obstruct recruitment by sending anti-draft leaflets to men who had been called for military service in the First World War. Although he conceded that individuals ordinarily had a right to express their views, Holmes held that this right did not protect speech that endangered other social interests. "The question in every case," he wrote, "is whether the words used are used in such circumstances and are of such a nature as to create a clear and present danger that they will bring about the substantive evils that Congress has a right to prevent." ${ }^{147}$ As

\footnotetext{
139 Id. at 344.

140 See id. at 344, 354-55.

141 Id. at 344.

142 See GraBer, supra note 135, at 65-74; HorwItz, supra note 129; Rabban, Progressive Social Thought, supra note 135.

143198 U.S. 45 (1905).

144 See Rabban, Progressive Social Thought, supra note 135, at 955.

145 See, e.g., Pound, supra note 135, at 454-56.

146249 U.S. 47 (1919).

147 Id. at 52.
} 
Schenck and other cases made clear, this standard was satisfied whenever, in the legislature's judgment, speech had a tendency to cause social harm. ${ }^{148}$

In this way the rejection of natural rights threatened to undermine the constitutional basis for protecting free speech. The central challenge of modern First Amendment theory has been to reconstruct a justification for that freedom within the framework of post-natural-rights jurisprudence. A leading effort in this direction came from Zechariah Chafee, Jr., a Harvard law professor who was to become the most influential First Amendment scholar of the first half of the century. ${ }^{149}$ In a 1919 article and a book published the following year, Chafee criticized Schenck and other Espionage Act decisions for treating free speech "as merely an individual interest, which must readily give way like other personal desires the moment it interferes with the social interest in national security."150 Instead, Chafee argued that the most important purpose served by free speech was the social interest in "the discovery and spread of truth on subjects of general concern." 151

This approach was soon adopted by Justice Holmes himself. Dissenting in Abrams v. United States, ${ }^{152}$ Holmes began by observing that, when the expression of opinions threatens important social objectives, suppression appears to be a "perfectly logical" response ${ }^{153}$ - essentially the basis of his decision in Schenck. Nevertheless, he continued, "when men have realized that time has upset many fighting faiths, they may come to believe even more than they believe the foundations of their own conduct that the ultimate good desired is best reached by free trade in ideas - that the best test of truth is the power of the thought to get itself accepted in the competition of the market, and that truth is the only ground on

148 See, e.g., Debs v. United States, 249 U.S. 211, 216 (1919) (upholding conviction of political speaker for obstructing or attempting to obstruct military recruitment where "the words used had [this] as their natural tendency and reasonably probable effect"); David M. Rabban, The First Amendment in its Forgotten Years, 90 YALE L.J. 514, 58586 (1981). Justice Holmes' opinion in Schenck was consistent with his long-held view that individual interests must be sacrificed where necessary to promote the common good. See Holmes, Common LAw, supra note 131, at 37, 40-41, 86-87; Horwitz, supra note 129, at 110-11; David M. Rabban, The Emergence of Modern First Amendment Doctrine, 50 U. CHI. L. REV. 1205, 1265-78 (1983) [hereinafter Rabban, Emergence].

149 On Chafee, see GRABER, supra note 135, at 122-64; Rabban, Emergence, supra note 148 , at $1283-1303$.

150 Zechariah Chafee, JR., Freedom of Speech 37 (1920); Zechariah Chafee, Jr., Freedom of Speech in War Time, 32 HARV. L. REV. 932, 959, 968-69 (1919).

151 CHAFEe, supra note 150, at 34; Chafee, supra note 150, at 956. In emphasizing the importance of free discussion to the "social interest in the attainment of truth," CHAFEE, supra note 150, at 36, Chafee followed a course that had been marked out a halfcentury earlier, in John Stuart Mill's comparable effort to defend freedom of speech and thought on grounds of utility rather than "abstract right." JOHN STUART MiLL, ON LiBERTY 12 (David Spitz ed., W.W. Norton \& Co. 1975) (1859).

152250 U.S. 616 (1919)

${ }^{153} I d$. at 630 (Holmes, J., joined by Brandeis, J., dissenting). 
which their wishes safely can be carried out."154 In referring to "fighting faiths," Holmes may well have been thinking in part of the abolitionism to which he had been committed in his youth, and which he believed had led to the devastation of the Civil War. In this way, he laid the foundations of modern free speech jurisprudence on the ruins of the natural rights theory which originally supported the First Amendment.

Although Chafee regarded the social interest in truth as extending to all "subjects of general concern," he believed that free speech had special importance in the political realm, "so that the country may not only adopt the wisest course of action, but carry it out in the wisest way." 155 The relationship between free speech and democratic self-government was stressed by Justice Brandeis in his concurring opinion in Whitney v. California, ${ }^{156}$ which argued that freedom of speech and thought were "means indispensable to the discovery and spread of political truth."157 This recognition of the social values of speech led Holmes and Brandeis to reinterpret the clear-and-present-danger standard to require not merely some tendency to cause social harm, but an imminent danger of serious evil. ${ }^{158}$

As Mark A. Graber and David M. Rabban have shown, these early efforts to reconstruct First Amendment theory accorded with the desire of many Progressives to defend freedom of speech without appealing to fundamental rights, which they tended to identify with Lochnerism. ${ }^{159}$ In this way, they could support free speech as necessary for an open political system, while denying the charge of judicial interference with substantive policy decisions of the legislature. This processoriented view was sketched in Justice Stone's famous footnote in United States v. Carolene Products, ${ }^{160}$ which suggested that laws interfering with speech or association might be subject to "more exacting judicial scrutiny" on the ground that they "restrict[ed] those political processes which ordinarily can be expected to bring about the repeal of undesirable legislation."161

Although Progressives were critical of the notion of fundamental rights, they nevertheless recognized that free speech was important for individuals as well as for

154 Id.

155 CHAFEE, supra note 150, at 34, 36; Chafee, supra note 150, at 956, 958.

156274 U.S. 357 (1927).

157 Id. at 375 (Brandeis, J., joined by Holmes, J., concurring).

158 See id. at 373-79; Abrams, 250 U.S. at 630-31 (Holmes, J. dissenting).

159 See Graber, supra note 135, at 122-64; Rabban, Progressive Social Thought, supra note 135. In this respect, Progressives rejected not only the classical justification for free speech, see supra Part I.A, but also the views of some laissez-faire conservatives and libertarian radicals, who continued to defend free speech on individualist grounds, see GRABER, supra, at 17-49, 53-65; David M. Rabban, The Free Speech League, the ACLU, and Changing Conceptions of Free Speech in American History, 45 Stan. L. REV. 47 (1992).

160304 U.S. 144 (1938).

$161 \mathrm{Id}$. at 152-53 n.4. For a contemporary version of this approach to the First Amendment, see John Hart Ely, Democracy AND Distrust 93-94, 105-16 (1980). 
society. Elaborating Pound's observation that individuals had an interest in the "free exercise of [their] mental and spiritual faculties,"162 Chafee held that the First Amendment protected not only the social interest in truth, but also the need of many individuals to "express their opinions on matters vital to them if life is to be worth living." 163 Of course, as long as this value was understood as "merely an individual interest," it was unlikely to prevail when balanced against important social interests. ${ }^{164}$ Yet the notion of fundamental rights was too deeply rooted in the American constitutional tradition to remain eclipsed for long. ${ }^{165}$ The role of the First Amendment in protecting individual liberty was a central theme of Justice Jackson's majority opinion in West Virginia State Board of Education v. Barnette, ${ }^{166}$ which held that a compulsory flag salute "invade[d] the sphere of intellect and spirit which it was the purpose of the First Amendment . . to reserve from all official control."167 Earlier, Justice Brandeis had characterized this liberty in more positive terms, asserting that the First Amendment had been adopted in the belief "the final end of the state was to make men free to develop their faculties."168 This individual-liberty view has gained increased momentum since the 1960s. ${ }^{169}$

\section{Classical versus Modern Free Speech Theory}

These three views - which focus on the value of free speech for the attainment of truth, democratic self-government, and individual liberty-represent the most influential modern efforts to construct a justification for freedom of speech. Of course, each of these approaches has roots in the classical libertarian tradition of Locke, Cato, Jefferson, and Madison. It may therefore seem that we have come full circle,

162 Pound, supra note 135 , at 453.

163 CHAFEe, supra note 150 , at 36.

164 Chafee, supra note 150, at 37; see also Pound, supra note 135, at 454-56.

165 Ironically, one of the first signs of a revival came in the Carolene Products footnote itself, shortly after the demise of Lochner. Although best remembered for its formulation of a process-based approach to constitutional adjudication, the footnote opened on a different note, suggesting that legislation may also be subject to more intensive scrutiny when it "appears on its face to be within a specific prohibition of the Constitution, such as those of the first ten amendments, which are deemed equally specific when held to be embraced within the Fourteenth." United States v. Carolene Prods. Co., 304 U.S. 144, 152-53 n.4 (1938).

166319 U.S. 624 (1943).

167 Id. at 642 .

168 Whitney v. California, 274 U.S. 357, 375 (1927) (Brandeis, J., concurring).

169 In recent years, this view has been developed in differing ways by such writers as C. Edwin Baker, Thomas I. Emerson, Martin H. Redish, David A.J. Richards, and Thomas Scanlon. See C. Edwin Baker, Human Liberty and Freedom of Speech (1989); Martin H. Redish, Freedom of Expression: A Critical Analysis ch. 1 (1984); David A.J. RichARDS, TOLERATION AND THE CONSTITUTION 165-230 (1986); Emerson, General Theory, supra note 25, at 879-81; Thomas Scanlon, A Theory of Free Expression, 1 PHIL. \& Pub. AfF. 204 (1972). 
and that the result of modern First Amendment theory has been to reproduce the essential features of classical libertarian theory. But this impression would be mistaken. To begin with, the classical theory regarded the values of free speech as a relatively unified whole, while the modern justifications are sometimes represented as distinct from, or even opposed to, one another. ${ }^{170}$ Over time, however, these different rationales have often come to be seen as elements of a more general theory of freedom of expression. ${ }^{171}$

A more fundamental difference relates to the nature of the justifications offered by the classical and modern views. Whereas the former sought to justify free speech primarily on intrinsic grounds, as a right of human nature and republican citizenship, the modern approach is more instrumental, focusing on the individual and social interests that speech serves. On this view, our constitutional commitment to free expression ultimately rests on an empirical judgment as to the best means of promoting the social good. In Justice Holmes' words, it is "an experiment... based upon imperfect knowledge," which is subject to revision or rejection in light of experience. ${ }^{172}$

Most importantly for the purposes of this Article, the classical and modern views conceptualize First Amendment issues in fundamentally different ways. For the classical view, many free speech problems involved rights on both sides. As we have seen, Progressive jurisprudence recharacterized rights as interests, and held that individual interests had value only insofar as they promoted those of society. In this way, individual rights came to be absorbed into the concept of social interests. Initially, First Amendment problems were reconceived as conflicts between two sets of social interests: those that were promoted by free speech and those that might be injured by it. Over time, free expression has once more come to be regarded as a right, whether for intrinsic or instrumental reasons or both. But this revival of rights in First Amendment jurisprudence has not extended to the values that may be harmed by speech, which continue to be characterized as social interests. In this way, we have come to a hybrid position which conceives of First Amendment issues as conflicts between free speech rights and social interests.

This transformation has crucial implications for the way we approach First Amendment problems. On the classical view, rights had inherent limits, which

170 See, e.g., Alexander Meiklejohn, Political Freedom 54-55 (1960) (rejecting Chafee's view that First Amendment protects an individual as well as a social interest); Robert H. Bork, Neutral Principles and Some First Amendment Problems, 47 IND. L. J. 1, 24-26 (1971) (arguing that First Amendment protects only political speech).

171 See Emerson, General Theory, supra note 25, at 878-86.

172 Abrams v. United States, 250 U.S. 616, 630 (1919) (Holmes, J., dissenting). Indeed, on this account, our current acceptance of free speech does not even guarantee the continued existence of constitutional liberty. As Holmes put it in Gitlow v. New York, 268 U.S. 652 (1925), "If in the long run the beliefs expressed in proletarian dictatorship are destined to be accepted by the dominant forces of the community, the only meaning of free speech is that they should be given their chance and have their way." Id. at 673 (Holmes, J., dissenting). 
derived from the nature of particular rights, their place within the larger framework of rights, and the duty to respect the rights of others. Although rights could sometimes conflict, this was the exception rather than the rule. Finally, in determining the legitimacy of restrictions on freedom, the classical view looked to a relatively objective standard - whether they were necessary to protect the rights of others.

Interest jurisprudence differed on each point. Unlike rights, interests were defined in largely subjective terms, as desires, needs, claims, or demands. ${ }^{173}$ Such interests had no fixed bounds, but extended as far as the desires or demands that they represented. As a result, interests necessarily conflicted with one another. Moreover, there was no objective standard by which to resolve such conflicts, other than the rather elusive and indeterminate notion of social utility. ${ }^{174}$

Several points follow for the modern understanding of First Amendment problems. First, there is no inherent limit to the interest in free speech, other than the desire to engage in it. The same is true when free speech is reconceived as a right coextensive with that interest. By the same token, there are no inherent limits to the social interests that may come into competition with speech. It follows that there is an inescapable conflict between free speech and other interests. Finally, there is no objective standard by which to resolve such conflicts.

The classical and modern views differ not only on the substantive nature of First Amendment problems, but also on their formal structure. For the classical view, such problems involved a trilateral relationship between (1) those who desired to speak or listen to others speak; (2) those whose rights might be affected by that speech; and (3) the state, which was bound to respect and protect the rights of both sides. On the modern view, the rights of others are reconceived as social interests, and the state is regarded as the representative of such interests. Indeed, despite Pound's efforts to distinguish them, ${ }^{175}$ the terms "social interests" and "state interests" are generally used interchangeably. In this way, First Amendment problems come to be viewed in terms of a bipolar opposition between the state and those who wish to engage in expression - a view that is applied not only to cases involving political speech or criticism of government, but also to cases involving speech that impacts on private parties.

173 See ChAFEE, supra note 150, at 35 (equating interests with "desires and needs"); John Chipman Gray, The NATURE AND SourCES OF THE LAW 18 (Roland Gray ed., 2d ed. 1921 \& photo. reprint 1972) ("By the interests of a man is meant the things which he may desire."); Pound, supra note 135, at 343 (referring to individual interests as "the demands which individuals may make"); $i d$. at 344 (defining an interest as "a claim which a human being or a group of human beings may make").

174 For a classic statement of this point, see Holmes, Path of the Law, supra note 131, at 466 (observing that judicial decisions ultimately rest on policy considerations that are "not capable of exact quantitative measurement," and that therefore "can do no more than embody the preference of a given body in a given time and place").

175 See Pound, supra note 135 , at 345. 


\section{E. The Dilemma of Modern First Amendment Theory}

In short, modern First Amendment theory perceives an inherent conflict between freedom of speech and the state's efforts to promote other social values. There are three basic approaches that one may take to First Amendment problems when they are understood in this way: (1) a statist position, which would generally defer to the government's power to regulate for the common good; (2) a civil libertarian view, which would generally protect freedom of speech; and (3) an approach that would seek to balance free speech and state interests. Each of these approaches suffers from serious difficulties, however - a result that should lead us to reexamine the conceptual framework of modern First Amendment theory.

The statist view would allow government broad power to regulate speech in the same way that it regulates conduct. ${ }^{176}$ Although this approach affords protection to the social interests that may be injured by expression, it provides little or no protection to freedom of speech. For this reason, it is clearly inadequate as an interpretation of the First Amendment.

By contrast, the civil libertarian view seeks maximal protection for free expression (and other individual rights) against state power. Yet just as statism fails to define the bounds of that power, civil libertarianism is unable to identify appropriate limits to free speech. Since it no longer appears possible, within a modern framework, to distinguish between legitimate and illegitimate restrictions, the modern defense of free speech tends toward absolutism.

Arguments for absolutism have taken a variety of forms. The most straightforward relies on a literal reading of the First Amendment. ${ }^{177}$ Despite its great rhetorical force, this approach is unconvincing, for it is not required by the text and has doubtful support in the original understanding. ${ }^{178}$

176 As we have seen, this was the effect of the clear-and-present-danger test in its original form. See supra note 148 and accompanying text. For a contemporary version of the statist view, as applied to all but explicitly political speech, see Bork, supra note 170 , at $20-35$.

177 The foremost proponent of this approach was Justice Hugo Black. See, e.g., Konigsberg v. State Bar of Calif., 366 U.S. 36, 60-62, 75 (1961) (Black, J., dissenting); Smith v. California, 361 U.S. 147, 157-58 (1959) (Black, J., concurring); Beauharnais v. Illinois, 343 U.S. 250, 274-75 (1952) (Black, J., dissenting). For similar reliance on the "absolute" language of the First Amendment, see MeIKLEJOHN, supra note 170, at 20-21.

178 See supra notes 26-27, 109-15, and accompanying text. In several opinions, Justice Black relied on the Republican position during the Sedition Act controversy to show that the First Amendment was an absolute, and further argued that, under the Fourteenth Amendment, the same absolute prohibition applied to the states. See, e.g., New York Times v. Sullivan, 376 U.S. 254, 295-97 (1964) (Black, J., concurring); Smith v. California, 361 U.S. 147, 157-58 (1959) (Black, J., concurring). This argument is unpersuasive for two reasons. First, as we have seen, at the time the First Amendment was adopted, there was no clear understanding that it was an absolute. See supra notes 109-15 and accompanying text. Second, even if we accept the Republican view of the original understanding, that would not support an originalist argument for holding that the First Amendment is equally absolute as applied to the states. The Republicans' 
The case for First Amendment absolutism has also been made on more substantive grounds. First, some writers have advanced what may be called the "global balancing" argument, which holds that a weighing of the costs and benefits of free speech leads to the conclusion that "freedom is always expedient."179 Although it initially seems plausible, this contention is also unpersuasive. It is undoubtedly true that, on the whole, the benefits that flow from free speech far exceed the harms, and that a society with absolute freedom of speech would be far better off than one with none. The fallacy, of course, lies in the implicit assumption that these are the only alternatives. From an interest-balancing perspective, the object is to determine the optimal balance between liberty and regulation. On this view, free speech should receive protection up to the point where its marginal benefits are outweighed by its marginal costs. Of course, rule utilitarianism teaches that such determinations often should be made on the level of general categories rather than individual acts. ${ }^{180}$ It seems clear, however, that there are many classes of speech whose regulation would promote social utility. ${ }^{181}$ It follows that absolute protection for speech cannot be successfully grounded on a balancing of social interests.

Other absolutist arguments avoid balancing and instead contend that freedom of speech has categorical priority over other social interests. For example, Alexander Meiklejohn contends that our society's most fundamental purpose is its commitment to democratic self-government. ${ }^{182}$ Political deliberation orders all other ac-

absolutism was based on notions of federalism, rather than on a substantive conception of the freedoms of speech and press. As a substantive matter, Republicans believed that those freedoms were limited by the rights of others. They contended, however, that the First Amendment was intended to deny the federal government all power over the press, while leaving any legitimate power to the states. See supra notes 113-15 and accompanying text. The framers of the Fourteenth Amendment appear to have shared this substantive view of freedom of expression. See supra Part I.B. When the freedoms of speech and press are applied to the states through the Fourteenth Amendment, it is the substantive understanding of those freedoms that should be applied, rather than any special federalism-based restrictions the Amendment may have been intended to impose on the national government. See AmAR, supra note 111, at 233-34.

179 MeIKLEJohn, supra note 170, at 57; see also Emerson, General Theory, supra note 25, at 916. In Konigsberg v. State Bar of California, 366 U.S. 36 (1961), Justice Black asserts that "the First Amendment's unequivocal command... shows that the men who drafted our Bill of Rights did all the 'balancing' that was to be done in this field." Id. at 61 (Black, J., dissenting); see also Beauharnais v. Illinois, 343 U.S. 250, 275 (Black, J., dissenting). In this form, the argument simply projects modern interest analysis back onto the eighteenth century.

180 For defenses of "categorical" or "definitional" balancing, see John Hart Ely, Flag Desecration: A Case Study in the Roles of Categorization and Balancing in First Amendment Analysis, 88 HARV. L. REV. 1482 (1975); Melville Nimmer, The Right to Speak from Times to Time, 56 CALIF. L. REV. 935 (1968).

181 For examples, see supra note 23.

182 See MeIKLEJOHN, supra note 170, at 18. 
tivities and determines their value. ${ }^{183}$ It therefore has "an authority over them all which is wholly incongruous with the notion that one of them, or all of them together, might be balanced against it." 184 It is on these grounds that "the absoluteness of the First Amendment rests." 185

An alternative argument appeals not to democratic self-government but to individual liberty. As Thomas Emerson puts it, "the purpose of society, and of its more formal aspect the state, is to promote the welfare of the individual."186 A person has a "right to express his beliefs and opinions" both as an individual and as a member of the community. ${ }^{187}$ For this reason, "[t]o cut off his search for truth, or his expression of it, is ... to elevate society and the state to a despotic command and to reduce the individual to the arbitrary control of others." 188 Emerson concludes that, while a "society may seek to achieve other or more inclusive ends," such as justice, equality, or the self-fulfillment of its citizens, it generally may not do so by suppressing individual expression, which must be afforded "full protection" under the First Amendment. ${ }^{189}$

Although this argument persuasively shows that free speech rights may not be subordinated to social welfare in general, it fails to recognize the possibility that individuals may also have other fundamental rights, the protection of which may justify regulation of speech. In this respect, Emerson's references to the liberty and welfare of "the individual" are somewhat misleading, for many free speech cases implicate the rights of more than one person. The proposition that one's rights may not be restricted for the sake of social welfare does not entail that they may not be limited to protect other rights. ${ }^{190}$

Emerson's view is also subject to a more general objection which applies to Meiklejohn's as well. While such arguments may establish the priority of free speech over social interests in general, they fail to demonstrate its priority over other fundamental rights, because the same sorts of arguments can be made on behalf of those rights. For example, while it is true that democratic self-government

183 See id. at 60.

184 Id.; see also id. at 55.

$185 \mathrm{Id}$. at 55.

186 Emerson, General Theory, supra note 25, at 880.

187 Id.

$188 I d$.

$189 I d$; ThOMAs I. EMERSON, THE SySTEM OF FrEEdOM OF EXPRESSION 17 (1970) [hereinafter EMERSON, SYSTEM].

190 In a later section of General Theory, Emerson recognizes this point, holding that individual interests should be treated differently than social goals in general, and that some such interests, such as reputation and privacy, may justify restrictions on speech. See Emerson, General Theory, supra note 25, at 920-28. This view is in obvious tension with Emerson's more general position that speech should enjoy full protection. It is therefore not surprising that, in his later work, Emerson sharply retreats from this view and adheres more closely to an absolutist position. See EmErson, System, supra note 189 , at $\mathrm{v}, 517-62$. 
depends on political free speech, the latter seems to depend on individual liberty of speech and thought. Unless they enjoy such liberty, individuals will be incapable of participating in self-government. It may seem, therefore, that individual free speech is a more fundamental right than its political counterpart. In another sense, however, the reverse may be true: as Meiklejohn contends, individual liberties may depend on the existence of political freedom. In this way, it becomes clear that these two aspects of free speech are interdependent, and that neither is more basic than the other. Freedom of speech must be viewed as a unified system, which includes both individual and collective elements. ${ }^{191}$

The argument may now be revised to assert that it is freedom of speech as a whole that has precedence over other social interests. ${ }^{192}$ Once more, however, the same kinds of arguments can be made for the priority of other rights. For instance, individuals cannot speak freely if they are not secure against violence. In this way, free speech depends on the right to personal security. Again, it does not necessarily follow that the latter is more fundamental than the former. Instead, just as individual and political free speech turned out to be interdependent, the same is true of free speech and other fundamental rights. It is only when these rights are taken as a whole, as a system of constitutional liberty, that they have priority over other interests. ${ }^{193}$

Although we cannot fully explore all the arguments that have been made for First Amendment absolutism, this discussion should suffice to indicate some of the problems that it faces. Recognizing these difficulties, civil libertarians often defend freedom of speech in less absolute terms. For example, many follow Chafee in endorsing a form of balancing that gives heavy weight to free speech. ${ }^{194}$ Despite its attractions, this approach only compounds the problem: the nearer it comes to absolutism, the more it is subject to the same objections, while as a form of balancing it also suffers from the difficulties of that approach. ${ }^{195}$

In summary, while civil libertarianism provides strong protection for free speech, it is unable to identify the limits of that freedom. This point might be of little concern if it simply meant that free speech were overprotected at the expense of social welfare in general. As civil libertarians point out, this may properly be regarded as "the price to be paid for constitutional freedom."196 For three reasons, however, the inability to identify limits should be of concern to civil libertarians themselves. First, the lack of an adequate theory to distinguish justified from unjustified restrictions makes it more difficult to successfully oppose the latter. Second, as we have seen, what modern First Amendment theory labels "social wel-

191 See EMERSON, SySTEM, supra note 189, at 6-9.

192 This is how Emerson appears to present the argument in his later work. See id.

193 See infra note 386 (discussing John Rawls' concept of "the priority of liberty").

194 See, e.g., CHAFEe, supra note 150, at 34; REDISH, supra note 169, at 52-55.

195 See infra notes 199-203 and accompanying text.

196 Young v. American Mini Theatres, 427 U.S. 50, 88 (1976) (Stewart, J., joined by Brennan, Marshall, \& Blackmun, JJ., dissenting); see also RONALD DwORKIN, TAKING RightS SERIOUSLY 193 (1978). 
fare" includes the rights of others. For this reason, a maximalist approach to freedom of speech has the unintended effect of sacrificing other individual rights-rights which, under other circumstances, civil libertarians might themselves defend against infringement by government. ${ }^{197}$ Finally, by protecting speech even when it wrongfully invades the rights of others, this approach tends to undermine the normativity of free speech-its character as a right. In this way, an excessive defense of free speech may weaken the legitimacy - and thus the public acceptance — of the very right that it means to defend. ${ }^{198}$

The third approach, balancing, seeks to avoid the pitfalls of both statism and civil libertarianism. In recognizing that both free speech and competing interests have important value, and that neither should be unreasonably sacrificed to the other, balancing is appealing from a common sense standpoint. From a theoretical perspective, however, balancing is perhaps the least coherent of the three approaches, for it is difficult to see how free speech and state interests are to be balanced against each other. As originally conceived by Pound and others, a major purpose of interest jurisprudence was to reduce competing values to common terms - those of social welfare - so that they could be weighed on the same scale. On this view, applied by Chafee to the First Amendment, free speech and other interests should be measured in order to determine what result would most promote the common good. ${ }^{199}$ Yet the common good provided only an indeterminate standard for deciding between social interests. ${ }^{200}$ Moreover, balancing social interests is often thought to be an essentially legislative function. ${ }^{201}$ Thus, this ap-

197 For example, the American Civil Liberties Union strongly defends the right to privacy against governmental actions disclosing private information about individuals. See, e.g., E.B. v. Verniero, 119 F.3d 1077 (3d Cir. 1997) (litigation challenging New Jersey Megan's Law, supported by state ACLU). At the same time, the ACLU holds that publication of private facts by the media falls within the freedom of speech and press, and therefore opposes laws allowing recovery for invasion of privacy in such cases. See American Civil Liberties Union, Policy Guide, policy \# 6(d)(4), at 13 (Jan. 1993).

198 Insofar as free speech is regarded as one social interest in competition with others, its supporters cannot be faulted for making the strongest possible claims for it, in the knowledge that other interests will also have strong advocates. In the case of free speech, however, those claims generally are - and must be - made in terms of principle. Excessive claims of this kind may be self-defeating, at least in the long run, because they tend to discredit the principle that they contend for.

199 See CHAFEE, supra note 150, at 34-35.

200 On the indeterminacy of interest balancing, see supra note 174 and accompanying text.

201 See Dennis v. United States, 341 U.S. 494, 525 (1951) (Frankfurter, J., concurring in judgment). 
proach — what may be called quantitative balancing - failed to ensure strong protection for free speech. ${ }^{202}$

For this reason, the thrust of most modern First Amendment theory has been to reverse the efforts of Pound and Chafee, and to show that freedom of speech is qualitatively different from other social interests. ${ }^{203}$ When we view free speech in this way, however, it is difficult to see what it would mean to balance free speech against other social interests. This is even more true when free speech is reconceived as an individual right. In short, while a quantitative approach to balancing fails to adequately protect expression, a qualitative approach appears to be impossible.

\section{F. Conclusion}

Each of the three major positions in modern First Amendment thought has serious flaws. These problems stem from the way that civil liberties issues are conceived of in modern jurisprudence, as conflicts between free speech and state interests - a term within which the rights of others have been absorbed. When the problem is understood in this way, strong protection for freedom of speech results - unintentionally but necessarily - in sacrificing the rights of others, while upholding state interests results in sacrificing freedom of speech. Modern First Amendment theory offers no coherent solution to this dilemma.

This problem - which goes to the heart of modern free speech jurisprudence - stems from its failure to recognize the rights of others as an independent element in First Amendment cases. The inadequacy of this view should lead us to give renewed consideration to a rights-based approach to free expression. This does not mean, of course, that we should simply return to the eighteenth-century understanding, even if that were possible. While a contemporary theory of the First Amendment must be rooted in our constitutional tradition, it must ultimately reflect our own best understanding of free expression and other rights. The remainder of this Article seeks to develop such a theory.

\section{FREE SPEECH IN A FRAMEWORK OF RightS}

\section{A. Introduction}

In this and the following Part, I outline the major features of a rights-based theory of freedom of expression. The present section discusses the conception of

202 This point emerged most dramatically in Dennis v. United States, 341 U.S. 494, 510 (1951), in which the Supreme Court upheld the convictions of leaders of the Communist Party under a generalized balancing test.

203 See supra notes 182-89 and accompanying text (discussing views of Meiklejohn and Emerson). As we have seen, these attempts were often directed to showing that freedom of speech should receive absolute protection. Although in this respect they were unsuccessful, they nevertheless succeeded in showing the ways in which free speech is distinct from other social interests. 
rights on which this view is based, and then describes the basic model of free speech and its limits.

\section{Liberty and Rights}

There are many different ways to argue that human beings have fundamental rights - rights that are not derived merely from positive law, and that the law ought to recognize. ${ }^{204}$ In this Article, I shall draw on the liberal natural rights tradition identified with Locke and Kant. As we have seen, this tradition profoundly shaped the understanding of free speech and other civil liberties throughout much of American history, particularly when the Bill of Rights and the Fourteenth Amendment were adopted. Despite the impact of legal positivism and utilitarianism, this tradition continues to represent a deep current in American thought, as evidenced by the contemporary revival of fundamental rights adjudication ${ }^{205}$ and contractarian political philosophy. ${ }^{206}$ For these reasons, this tradition can provide valuable insight into the proper place of free speech within our legal and constitutional order.

For the natural rights tradition, rights derive from the concept of liberty. The most basic meaning of liberty is self-determination: a free person is the author of her own thoughts and actions, rather than being determined by something other than herself. ${ }^{207}$ On this account, freedom has two aspects: in a negative sense, it means independence from determination by external forces or stimuli, while in a positive sense it means the capacity to actively determine one's own thoughts and actions. ${ }^{208}$ Freedom in relation to other persons consists in the (positive) capacity to determine one's own actions without (negative) interference by others. ${ }^{209}$

204 For some leading contemporary works on rights theory, see DWORKIN, supra note 196; Alan Gewirth, Reason and Morality (1978); John Rawls, A Theory of Justice (1971) [hereinafter Rawls, Theory of Justice]; John Rawls, Political Liberalism (1993); Joseph Raz, The Morality of Freedom (1986); Judith Jarvis Thomson, The REALM OF RightS (1990); THEORIES OF Rights (Jeremy Waldron ed., 1984).

205 See, e.g., Griswold v. Connecticut, 381 U.S. 479 (1965); Roe v. Wade, 410 U.S. 113 (1973).

206 See, e.g., Robert Nozick, AnArchy, State, And Utopia (1974); RAwls, Theory of JUSTICE, supra note 204.

207 In this Article I shall alternate between masculine and feminine generic pronouns.

208 This account of negative and positive liberty is implicit in Locke, see LOCKE, ESSAY, supra note 33, bk. II, ch. XXI, and is more fully developed in the works of Kant and Hegel, see Immanuel Kant, Foundations of the Metaphysics of Morals *446-47 (Lewis W. Beck trans., 2d ed., MacMillan Publishing Co. 1990) [hereinafter Kant, Foundations]; Immanuel Kant, The Metaphysics of Morals *213-14 (Mary Gregor trans., Cambridge Univ. Press 1991) [hereinafter Kant, Metaphysics of Morals]; G.W.F. Hegel, Elements of the Philosophy of Right §§ 5-7 (Allen W. Wood ed., H.B. Nisbet trans., Cambridge Univ. Press 1991).

209 See Locke, Two Treatises, supra note 29, II § 6; 1 Blackstone, supra note 50, at *125. For a discussion of these two aspects of liberty in classical liberal thought, see Steven J. Heyman, Positive and Negative Liberty, 68 CHI.-KenT L. REV. 81 (1992). 
As a free person, I have a right (that is, a justifiable claim) to my liberty and personality. This status is not unique to me, however, but is one that I share with other human beings. Thus my rights entail a correlative duty to respect the liberty and personality of others. ${ }^{210}$ To put it differently, the concept of freedom includes immunity from interference. If freedom is to exist, then, it must be bounded by an obligation to refrain from interfering with the liberty of others. ${ }^{211}$

Right in general may be understood as freedom insofar as it is consistent with the equal freedom of others. ${ }^{212}$ Specific rights such as life, liberty, and property are instances of this freedom. ${ }^{213}$ Natural rights theory then develops the content of rights by exploring what it means to be a free person in different areas of life. These include (1) the individual's existence in the external world, (2) his inner life of thought and feeling, (3) his relationships with other persons and the community, and (4) his search for intellectual or spiritual meaning or truth.

\section{The Basic Model}

These four elements of human liberty correspond to the major justifications that have been advanced for freedom of speech and thought: that they are instances of external freedom in general ${ }^{214}$; that they are essential for individual selfrealization $^{215}$; that they are central to democratic self-government ${ }^{216}$; and that they are necessary for the attainment of truth. ${ }^{217}$ In this Part, I shall show that, in addition to freedom of expression, these dimensions of liberty also give rise to other rights, including individual rights such as privacy and personal security, as well as certain rights of the community itself, such as the authority to preserve the peace and protect its citizens. Because these rights derive from the same principles as freedom of speech, they are of the same order of value.

The central principle of the rights-based theory is the one that emerged from the natural rights background of the First Amendment: that free speech is a right that is limited by the fundamental rights of other persons and the community. More spe-

210 See, e.g., Locke, Two TrEATISES, supra note 29, II $\S 6$; HeGEL, supra note 208, $\S \S$ $36,38$.

211 See Locke, Two Treatises, supra note 29, II $\S 57$; 1 Blackstone, supra note 50, at *125; KANT, Metaphysics OF Morals, supra note 208, at *230-33.

212 See Kant, Metaphysics of Morals, supra note 208, at*230. Compare Rawls's first principle of justice: "Each person is to have an equal right to the most extensive total system of equal basic liberties compatible with a similar system of liberty for all."

RAWLS, THEORY OF JUSTICE, supra note 204, § 39, at 250.

213 See, e.g., 1 BlaCKSTONE, supra note 50, at *125, *129.

214 See, e.g., 1 CATO's LetTERS, supra note 24, No. 62.

215 See supra note 169.

216 See, e.g., MeIKLEJOHN, supra note 170.

217 See, e.g., Mill, supra note 151, ch. 2; John Milton, Areopagitica, in Areopagitica and Of Education (George H. Sabine ed., Appleton-Century-Crofts, Inc. 1951) (1644); Abrams v. United States, 250 U.S. 616, 624 (1919) (Holmes, J., dissenting). 
cifically, the theory holds that an act of expression is presumptively wrongful, and subject to legal regulation, when it (1) causes (2) an infringement of a fundamental right belonging to another, and (3) is done with a state of mind that should make the actor responsible for that result. Speech can cause injury to other rights either directly (as when $A$ threatens $B$ ) or indirectly (as when $A$ incites $B$ to attack $C$ ). To ensure broad protection for free speech, causation should be limited to cases in which an act of expression has a concrete and substantial impact on other rights. ${ }^{218}$ The precise scope of causation will vary, however, depending on such factors as the nature and value of the competing rights and the type of liability at issue (criminal, civil, injunctive, disciplinary). ${ }^{219}$ Similar factors are relevant to determining the standard of liability. In many cases, an individual should be held responsible only when she intentionally violates the rights of others. ${ }^{220}$ Other contexts may call for a different standard such as recklessness or negligence. ${ }^{221}$

The principle that free speech is limited by the rights of others is subject to several important qualifications. First, while rights may be clearly defined at the core, their outer boundaries are not fixed. 222 In determining the scope of a right, courts must consider the nature and value not only of that right, but also of the rights with which it may conflict. Thus, in some cases an apparent conflict can be resolved by adjusting the boundaries of the two rights. Second, even when speech is responsible for infringing another right, there is only a prima facie justification for regulation, for the value of the speech may be so great that it should be regarded as privileged. ${ }^{223}$ These two points will be explored in Part III.

218 Thus contemporary First Amendment jurisprudence rejects the common-law doctrine that speech is unlawful whenever it has a mere "tendency" to bring about illegal action or other social harms. For the common-law doctrine, see 4 BLACKSTONE, supra note 50 , at $* 152$.

219 For example, in view of the high value of political expression under the First Amendment, the Supreme Court has held that states may not proscribe the advocacy of law violation unless it is both intended and likely to produce "imminent lawless action.” Brandenburg v. Ohio, 395 U.S. 444, 447 (1969) (per curiam) (emphasis added). Presumably, however, this strict standard would not apply to private criminal solicitation, since such speech has far less value, while the threat it poses to other rights may well be greater. See R. Kent Greenawalt, Speech, Crime, and the Uses of Language 261-65 (1989). For a fascinating case on the scope of causation, see Rice v. Paladin Enters., 128 F.3d 233 (4th Cir. 1997), cert. denied, 118 S. Ct. 1515 (1998).

220 This is especially true where criminal sanctions are at stake. See, e.g., infra notes 253-54 and accompanying text (describing Brandenburg standard for criminal incitement).

221 For example, under New York Times v. Sullivan, 376 U.S. 254 (1964), liability for defamation of a public official may be based on reckless disregard for the truth, while under Gertz v. Robert Welch, Inc., 418 U.S. 323 (1974), private figures may be allowed to recover on a showing of negligence.

222 See Jeremy Waldron, Rights in Conflict, in Liberal Rights 203, 224 (1993).

223 A paradigm case is New York Times v. Sullivan, 376 U.S. 254 (1964), which is discussed in Part III.B.1 infra. 
Third, in its effort to do justice, the law must take account not only of what is right or wrong in itself, but also of the law's own nature and limitations. ${ }^{224}$ For instance, the law cannot properly regulate speech (or other activity) unless it is able to define the distinction between rightful and wrongful action in reasonably clear terms which are capable of being understood by those who must administer or comply with them. ${ }^{225}$ Regulation is also inappropriate if it is likely to do more harm than good to liberty taken as a whole. Again, government should have less authority to regulate in contexts where it is likely to be biased in favor of restriction. $^{226}$ I shall refer to considerations of this sort as those of institutional right. In some cases, they may justify according speech greater protection than it is entitled to as a matter of substantive right. This course should be followed, however, only where necessary to make the law more consistent with right as a whole.

In the remainder of this Part, I explore the four aspects of human liberty discussed above. In each case, I argue that this element not only supports a fundamental right to freedom of speech, but also grounds other rights that are equally implicit in the concept of a free person. Finally, I identify the ways that free speech can violate these rights, and argue that in such cases speech is properly subject to legal regulation, unless the value of the speech is such that it should be regarded as privileged. ${ }^{227}$

224 For recognition of this point in natural rights theory, see HEGEL, supra note 208, $\S 222$; Kant, Metaphysics of Morals, supra note 208, at *296-305; ERnest J. WeinRiB, The Idea of Private Law 106-07 (1995); see also Locke, Two Treatises, $s u$ pra note 29 , II $\S 205$.

225 This is the basis of the doctrines of vagueness and overbreadth.

226 See, e.g., New York Times v. Sullivan, 376 U.S. 255 (1964). For some defenses of freedom of speech that focus on the tendency of the government or society to restrict expression, see Frederick Schauer, Free Speech: A Philosophical Enquiry (1982); Vincent Blasi, The Pathological Perspective and the First Amendment, 85 Colum. L. Rev. 449 (1985); Emerson, General Theory, supra note 25, at 889-95.

227 In arguing that free speech is limited by other rights, I do not wish to rule out the possibility that some speech legitimately may be subject to broader regulation. As we have seen, classical natural rights theory held that some aspects of liberty were inalienable while others were alienable. The former were limited solely by the inherent rights of others, while the latter were also subject to regulation for the public good. See supra Part I.A. Similarly, modern constitutional law distinguishes between fundamental rights, which can be restricted only for compelling reasons, and nonfundamental rights, which are subject to reasonable regulation to promote the common welfare. While free speech generally should be regarded as a fundamental or inalienable right, this is not necessarily true of all categories of speech. For instance, it might be argued that commercial advertising, like other forms of business activity, should generally be considered a nonfundamental right which is subject to reasonable regulation, as in the case of tobacco-advertising restrictions designed to protect public health, see supra note 18 . For similar views of commercial speech, see BAKER, supra note 169, at 194-224; Thomas H. Jackson \& John Calvin Jeffries, Jr., Commercial Speech: Economic Due Process and the First Amendment, 65 VA. L. REV. 1 (1979). I shall not pursue such issues in this 


\section{B. Free Speech and External Rights}

According to natural rights theory, rights flow from one's status as a person. Personality has its basis in self-consciousness - in the individual's awareness of himself as a free, self-determining being. Self-consciousness does not exist in the abstract, however, but within a body and in relation to an external environment. The claims of personality in relation to this external realm constitute the first category of fundamental rights.

First, an individual has a right to life and, more broadly, to personal security, or sovereignty over one's own mind and body, free from violence or interference by others. This power over oneself includes the freedom to direct one's outward actions and movements without constraint. Finally, in order to sustain one's life and pursue one's actions in the world, one must have at least some control over external things. In this way we arrive at the traditional rights to life, liberty and property. ${ }^{228}$

In this section, I first show how these traditional rights provide a justification for freedom of speech and thought. I then analyze these rights in greater depth, particularly the right to personal security, and show how they can be violated by assaults and threats of violence. Although this limitation on speech is hardly controversial, exploration of this paradigm case will shed light on other, more difficult areas.

\section{Freedom of Speech as an External Right}

Freedom of speech and thought clearly fall within the scope of these traditional rights. The right to personal security relates to the mind as well as the body, and thus includes a right over one's own mental activity.229 The right to speak may be regarded as a species of personal liberty, or the right to direct one's external actions. ${ }^{230}$

We should note that these rights extend not only to thinking and speaking, but also to related forms of action. Individuals can express their ideas by producing sounds, making marks, or engaging in other actions. Of course, all of these actions fall within the concept of personal liberty, as do the acts of listening, reading, and observing. Moreover, liberty should be understood not merely as a power to

Article, however, but shall focus on the limitations on speech that arise from the rights of others, and that apply to all forms of expression.

228 For a classic discussion of these rights, see 1 BLACKSTONE, supra note 50, at *121-45.

229 See, e.g., Tucker, supra note 114, at 3 (including freedom of conscience and opinion under the heading of personal security).

230 See, e.g., CAto's LetTers, supra note 24, No. 62, at 429 (arguing that the magistrate has no legitimate concern with "what gestures I use, or what words I pronounce, when they please me, and do him and my neighbour no hurt"); Pound, supra note 135, at 453 (describing liberty of belief and expression as "a sort of free mental motion and locomotion"). 
act, but as a power to act or not act, according to one's own choice. ${ }^{231}$ Personal liberty therefore includes not only the right to speak, but also the right to remain silent. $^{232}$

\section{Other Rights}

To say that individuals have a general liberty to direct their own actions does not, of course, mean that those actions are always permissible. Individuals may use their freedom in such a way as to unjustifiably infringe the rights of other persons to their own life, liberty and property. Such actions are wrongful and may be restricted by law.

Acts of expression can clearly violate rights in this way. For example, an adherent of a "patriot movement" who blows up a federal office building in order to protest against oppression deprives the people inside of life and personal security. Similarly, protesters who blockade the entrance and occupy the grounds of an abortion clinic interfere with patients' liberty of movement, as well as with the clinic's right to property. ${ }^{233}$

As these examples show, the rights at stake may include not only those of individuals, but also those of the public. Individual rights exist under the protection of the community, both in the sense that the law affords remedies for their violation, and in the sense that the most serious invasions, such as those involving violence, are regarded as wrongs not only against the immediate victims but also against the community itself. In addition, the state has certain rights as a sovereign, an owner of property, an employer, and so on. Thus in the case of the federal building, the actor would be liable not only for the tort of wrongful death but also for the crimes of murder and destruction of government property. Likewise, the anti-abortion protesters may be guilty of criminal as well as civil trespass.

In all of these cases, of course, the injury results from the noncommunicative impact of expression - the effect that it would have had regardless of whether the actors intended to communicate a message or that message was understood by others. $^{234}$ But expression can also infringe rights because of its communicative impact. This point can best be seen by exploring the concept of personal security in more depth. In addition to showing the ways in which speech can violate this right, our analysis will provide valuable analogies for the discussion of other rights.

231 See LocKE, ESSAY, supra note 33, bk. II, ch. XXI, §§ 7-12.

${ }^{232}$ For further discussion of these points, see infra notes 274-76 and accompanying text.

233 In shutting down the clinic, the protesters also intentionally interfere with the patients' rights to reproductive freedom, part of the personal security and liberty protected against state interference by the Fourteenth Amendment under the Supreme Court's decisions in Roe v. Wade, 410 U.S. 113 (1973), and Planned Parenthood v. Casey, 505 U.S. 833 (1992).

${ }^{234}$ On the distinction between communicative and noncommunicative impact, see Ely, supra note 180, at 1497. 
The right to personal security derives from the relationship between the body and the self. ${ }^{235}$ This relationship exists on two levels. On one level, the two are not separate but form a natural whole: the self exists only in and through its body. Thus an injury to the body constitutes an injury to the self. ${ }^{236}$ Moreover, because the self feels through its body, an injury to the latter generally inflicts harm, in the form of pain or distress, on the former. In view of this natural unity, "[v]iolence done to my body by others is violence done to me." 237 As a free person, such violence is an infringement of my right to personal security, understood here as a passive or negative right to be free from interference by others.

The relationship between self and body is not merely given by nature, however, but is also constituted by the self. Because a person can exist and act only through her body, one of her most basic acts of self-determination must be to assert sovereignty over her own body. From this perspective, personal security is an active, positive right of the self to possess and control its own body.

This discussion suggests a further distinction that will be crucial to understanding the impact that expression can have on personal security. Because it derives from the relationship between the body and self, personal security has both an objective and a subjective element. The former protects the body-the object over which the self has a right - while the latter protects consciousness in relation to the body - the self's freedom from pain and distress, as well as its ability to exercise control over its body. To put it another way, the objective dimension consists of the right to be safe from bodily interference, while the subjective dimension consists of the right to reasonably believe oneself to be safe. Corresponding to these two dimensions are two kinds of wrongs against personal security: an injury to the objective element constitutes a battery, while an injury to the subjective element constitutes an assault.

In addition to acts of violence, battery includes such acts as spitting in another person's face or touching him sexually without his consent. Although such acts may cause little or no physical harm or pain, they nevertheless constitute battery because of their affront to the victims' dignity.

A classic account of dignity appears in the writings of Kant. As a natural being, man has a merely finite, extrinsic value, which is based on his usefulness for particular purposes, and which is commensurate with the value of other commodities. As an autonomous being, on the other hand, man "is not to be valued merely as a means to the ends of others or even to his own ends, but as an end in himself, that is, he possesses a dignity (an absolute inner worth). ${ }^{238}$ This dignity not only

235 The analysis in this and the following paragraph is derived largely from HEGEL, supra note 208, $\S \S 47-48,57$.

236 This notion is captured by the use of the word "person" as a synonym for the body, especially in traditional legal discourse. Thus "personal security" refers primarily to bodily safety.

237 HeGEL, supra note 208, § 48R.

238 Kant, Metaphysics of Morals, supra note 208, at *434-35. 
forms the basis of his own sense of self-esteem or self-respect, but also allows him to "exact[] respect for himself from all other rational beings in the world." 239

Taken together with our analysis of the two-fold relationship between self and body, this conception of human dignity provides the basis for an account of the wrongfulness of offensive battery. First, insofar as there is a unity between self and body, the dignity of the former extends to the latter as the external side of itself. Conversely, because the self feels through the body, whatever is done to the body affects the individual's self-consciousness, including her sense of dignity and selfrespect. Second, in asserting its authority over the body, the self invests the latter with its own dignity. What is done to the body thus affects its own dignity as well as that of the self. Offensive battery treats another's body not as the embodiment of a free being with intrinsic worth, but rather as a mere object that can be treated however the actor pleases. This is why offensive battery is wrongful.

An important point that emerges from this discussion is that the right to one's body has both a substantive and a formal aspect. A person has a substantive right against bodily harm, a right that is violated by harmful battery. But he also has a formal right to the integrity or inviolability of his body - a claim to be free from any contact with the body that is inconsistent with its dignity, or with the autonomy and intrinsic value of the self. ${ }^{240}$ This right is violated by offensive battery, the deliberate infliction of contact that "offends a reasonable sense of personal dignity." 241

The right to personal security extends beyond protection against battery. One who fires a gun at another but misses causes no bodily injury, but may nevertheless be liable for assault. The same is true of one who spits at another but misses. Assault inflicts an injury not to the body but to the consciousness of the victim. Insofar as there is a unity between self and body, a threat of harmful or offensive contact to the body is felt as a threat to the safety or dignity of the self. Assault also undermines the self's secure sense of authority in relation to the body.

In these ways, assault infringes the subjective aspect of personal security-the right to believe oneself to be safe from bodily invasions. Once more, we can distinguish between substantive and formal aspects of this right. The former is violated by acts that cause the victim to fear for his bodily safety or dignity. Suppose, however, that a person is aware that she faces imminent attack, yet suffers no fear or distress (perhaps because she is particularly brave or skilled in self-defense). In this case, although the act causes no substantive injury, it nevertheless infringes the in-

239 Id. at *435; see also KANT, FoundATIONS, supra note 208 , at *428-29.

240 In addition to illuminating the nature of personal security, this distinction between the substantive and formal aspects of a right will turn out to be vital for understanding rights of personality such as privacy. See infra notes 293-95 and accompanying text.

241 Restatement (SECOND) OF TORTs $§ 19$ (1965) [hereinafter RESTATEMENT]. 
violability of consciousness, by making the victim experience apprehension of a threat to her rights. ${ }^{242}$

Let us summarize the analysis up to this point. The right to personal security has not only an objective but also a subjective dimension. An injury to the objective element constitutes a harmful battery if it causes substantive harm to the body, and an offensive battery if it violates the formal right to bodily integrity. Injuries to the subjective element constitute assaults, which again may cause substantive harm to consciousness (fear) or violate its formal integrity (apprehension).

Thus far, the analysis has emphasized the categorical distinctions between various injuries to personal security. But these injuries can also be viewed on a continuum. In causing substantive harm to the body, harmful battery is the most objective injury. Offensive battery involves an injury to consciousness through the body, and thereby implicates both the objective and subjective aspects. Finally, assault is an injury to consciousness in its own right, and is therefore the most subjective injury.

We are now in a position to identify the ways in which expression can infringe the right to personal security. As we have seen, substantive bodily injury may be caused by the noncommunicative impact of expression - as in the case of blowing up the federal building. Communicative impact, on the other hand, is incapable of directly causing such harm. ${ }^{243}$ By definition, such impact is the effect that expression has not on the physical world, but on the consciousness of its hearers.

By the same token, however, the communicative aspect of expression is capable of violating personal security insofar as that right is one of consciousness-that is, insofar as it has a subjective dimension. It follows that, while communicative impact cannot inflict a harmful battery, it can play an essential role in causing an offensive battery or an assault - the two injuries we have discussed that have a subjective element.

The role of communicative impact in offensive battery is illustrated by two wellknown cases. In Alcorn v. Mitchell, ${ }^{244}$ a litigant spat in his adversary's face in the presence of a large number of people in the courtroom. ${ }^{245}$ In Fisher v. Carrousel Motor Hotel, ${ }^{246}$ a NASA scientist was standing in a luncheon buffet line during a conference, when the restaurant's manager snatched a plate out of his hand and shouted that he could not be served there because of his race. ${ }^{247}$ Both acts caused contact offensive to a reasonable sense of personal dignity, and thus constituted bat-

242 See id. $\S 24$, cmt. b (distinguishing between fear and apprehension, and holding that the latter is sufficient to support an action for assault).

243 The discussion here is confined to the direct effect that expression has on the listener. The communicative aspect of expression may, however, bring about such harm through its impact on third parties. See infra notes 252-54 and accompanying text (discussing incitement).

24463 Ill. 553 (1872).

245 See id. at 553.

246424 S.W.2d 627 (Tex. 1967).

247 See id. at 628-29. 
tery. In each case, the offensiveness of the contact derived primarily from its communicative impact. While it is highly unpleasant to be spat upon, and irritating to have an object snatched from one's hand, by far the greatest element of offense derived from the contempt that the acts expressed and the humiliation that they were intended to inflict. As the court remarked in Alcorn, they were acts "of pure malignity, done for the mere purpose of insult and indignity." 248

Communication plays an essential role in offensive battery because of the way that the tort implicates both the objective and subjective elements of personal security. The act treats the victim's body as a mere object or thing, rather than as the outward existence of a free being of intrinsic value, entitled to respect as such. In this way it injures the victim's consciousness through his body, and vice versa.

In assault, the element of consciousness comes to the fore. Not even minimal contact is required; instead, the essence of the injury is to the victim's sense of security and inviolability. Assaults can be divided into two categories: attempted battery and threats to commit battery. In the latter kind of case, the injury may be caused by the communicative aspect of expression - that is, by words that, taken together with other acts and circumstances, are intended to cause the victim to suffer fear or apprehension of imminent bodily injury. ${ }^{249}$ As we shall see, threats of future violence may also be unlawful. ${ }^{250}$ It is clear that assaults and threats, like physical violence, are unprotected by the First Amendment. ${ }^{251}$

Both assaults and threats violate personal security through their direct impact on the victim's mind. Speech can also infringe this right indirectly, through its effect on third parties. Thus, solicitation or incitement of violence may violate the objective aspect of personal security if the violence actually comes about, as well as the subjective aspect, if the victim becomes aware of the danger. Solicitation and incitement may also violate the community's right to the public peace. Much of the modern history of the First Amendment involves the Supreme Court's attempts to grapple with the problem of advocacy of illegal conduct. ${ }^{252}$ The Court's current formulation appears in Brandenburg v. Ohio ${ }^{253}$ which holds that the government may forbid such advocacy only where it is "directed to inciting or

24863 Ill. at 554.

249 See Restatement, supra note 241, § 31. Although the common law limited criminal assault to attempted battery, most states have expanded the crime to include threatened battery as well. See Wayne R. LaFave \& Austin W. Scott, JR., Criminal Law 693-94 (2d ed. 1986).

250 See infra note 255-59 and accompanying text.

251 See, e.g., R.A.V. v. City of St. Paul, 505 U.S. 377, 388 (1992) (noting that "threats of violence are outside the First Amendment" because of the fear and disruption that they cause); NAACP v. Claiborne Hardware Co., 458 U.S. 886, 916 (1982) ("The First Amendment does not protect violence" or "threats of violence.").

252 For an overview, see TRIBE, supra note 120, § 12-9.

253395 U.S. 444 (1969) (per curiam). 
producing imminent lawless action and is likely to incite or produce such action."254

\section{Free Speech and Rights of Personality}

In the preceding section, we saw that the right to personal security protects against invasions ranging from harmful battery to offensive battery to assault. As one moves along this continuum, the objective or external dimension of the wrong becomes less important, while the subjective or internal dimension - the injury to consciousness - moves to the foreground. There is no good reason, however, why this progression should end with assault. In State Rubbish Collectors Association v. Siliznoff, 255 for example, members of a business association threatened a rival with personal violence if he failed to comply with their extortionate demands. ${ }^{256}$ Because the threats related to the future, they did not fall within the traditional definition of an assault. As William L. Prosser observed, however, it seems arbitrary to allow "recovery for the movement of a hand that [may] frighten the plaintiff for a moment, [but to deny] it for coldly menacing words that [keep] him in terror of his life for a month." 257 In Siliznoff the California Supreme Court accepted this view, holding that serious threats of future violence were actionable in tort. ${ }^{258}$ In addition, such threats may give rise to criminal liability. ${ }^{259}$

In cases like Siliznoff, it becomes clear that the injury to be prevented is not merely the threat of violence, but also the serious mental and emotional distress that such threats may cause. If that is so, however, then there seems to be no principled reason to restrict liability to threats of violence. In Wilkinson v. Downton, ${ }^{260}$ for instance, the defendant falsely told the plaintiff that her husband had been seriously injured in an accident, causing her to suffer intense mental anguish. ${ }^{261}$ Recognizing that acts of this sort constitute serious wrongs, Wilkinson and subsequent cases fashioned the tort of intentional infliction of emotional distress. ${ }^{262}$

In this way, the development of external rights against violence naturally leads to a recognition of internal rights. Although personal security initially appears to be external, it turns out to have an internal dimension, deriving from the relation between the body and the self. As one moves from harmful battery to assault, this

254 Id. at 447.

255240 P.2d 282 (Cal. 1952).

256 See id. at 284-85.

257 William L. Prosser, Intentional Infliction of Mental Suffering: A New Tort, 37 Mich. L. REV. 874, 880 (1939).

258 See 240 P.2d at 285.

259 See, e.g., Model Penal Code And Commentaries $\S 211.3$ (1980) (providing that it shall be a felony to threaten to commit any crime of violence with purpose to terrorize another).

260 [1897] 2 Q.B.D. 57.

261 See id. at 58.

262 See Restatement, supra note $241, \S 46(1)$ \& cmt. k. 
internal dimension becomes more and more central. This development culminates in a right against infliction of emotional distress - a right which essentially protects the individual's consciousness rather than her bodily existence.

This movement from external to internal rights was an important theme in Samuel Warren and Louis D. Brandeis's classic article on The Right to Privacy. ${ }^{263}$ Early law, the authors argued, was primarily concerned with protection against violence and other tangible harm. As civilization progresses, however, people increasingly find their well-being not merely in material things, but also in an "intense intellectual and emotional life." 264 It was inevitable that the law should respond to this development by according protection to individuals in their thoughts, emotions, and sensations. ${ }^{265}$ Warren and Brandeis described the basic right involved as that of "an inviolate personality." 266

This discussion points to the existence of a second set of rights, which I shall call rights of personality. Like the traditional triad of life, liberty, and property, these rights are rooted in our nature as autonomous beings. The focus of selfdetermination has shifted, however: rather than acting in the external world, the self now turns inward to shape its own intellectual and emotional life. Rights of personality reflect what it means to be a free person in this internal realm.

Again, these rights can be understood in terms of both negative and positive liberty. ${ }^{267}$ By withdrawing from the external realm into itself, personality frees itself from all external limitations, thereby attaining the positive capacity to determine itself and its own activity. To translate the point into interpersonal terms, the individual asserts the power to shape his own inner life, free from unjustified interference by others.

In many ways, the structure of this second category of rights resembles that of the first (the external rights to life, liberty, and property). Just as the first category began with the right to one's body, the second begins with the right to one's personality - the capacity to autonomously determine one's own inner life without wrongful interference by others. Second, one has a right to express oneself through one's actions, which include both speech and conduct. This right is parallel to that of liberty in the external realm. The difference is that, while both rights relate to action, the latter regards action as outward movement, whereas the former views it as the expression of inward personality. Finally, through one's actions, one relates to others and makes impressions on them. These impressions, taken as a whole, constitute an individual's reputation. While reputation belongs to the self, in another sense it is external to the self, existing within the minds of others. In this way, reputation resembles the right to property, which also is external to the individual.

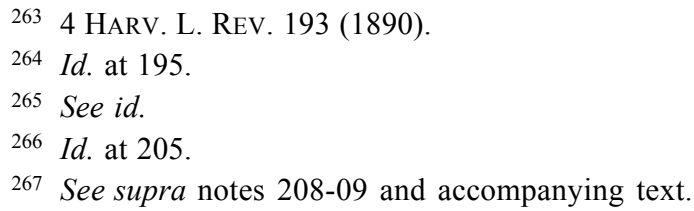


In this section, I shall first discuss the ways in which freedom of speech and thought can be understood as rights of personality. Then I shall explore the other rights that flow from personality, and show how they give rise to normative limits on speech similar to those arising from external rights. Finally, I shall consider several objections to the notion that the law ought to recognize rights of personality, or that these rights can provide a justification for regulating speech.

1. Speech, Thought, and Personality

\section{a. Speech and Thought as Rights of Personality}

At the core of personality is the right to self-determination. Speech and thought play an essential role in this process. In forming her own thoughts, beliefs, values, and emotions, an individual defines her identity and shapes her personality. She further defines herself through the expression of her thoughts and feelings to others. In both of these ways - through the inward formation of the self and its outward expression - an individual may be said to realize herself. ${ }^{268}$ Since self-realization is not a single event but a continuing process, it may also be described in terms of self-development. ${ }^{269}$ Finally, if we regard self-realization as an important or even ultimate end for human beings, it may also be said to promote self-fulfillment. ${ }^{270}$

Because of their crucial relation to these values, freedom of speech and thought constitute fundamental rights. As we have seen, such rights reflect what it means to be a free person in various spheres of life. To be free in a full sense, a person must be free not only externally, in his body and his relation to the external world, but also internally, with regard to his own inner life of thought and feeling, and in the expression of that inner life. Just as respect for persons mandated recognition of their rights to bodily security, liberty, and property, so it requires respect for individual personality itself, and for the expression and realization of that personality in the world. Thus unjustified restrictions on free speech are wrongful not merely because of the limitations they impose on external liberty, but also in a deeper way, because they obstruct the individual's right to autonomously determine, express, and realize his own personality.

Several additional points flow from this account. First, speech has value for self-realization because it expresses the thoughts and feelings of individuals. The purpose of the First Amendment is not merely to protect speech itself, but also the inner life that it expresses. For this reason, freedom of thought, belief, and feeling, although not mentioned in the constitutional text, should receive no less protec-

268 For leading accounts of freedom of speech as self-realization, see sources cited $s u$ pra note 169.

269 Self-development plays an important role in John Stuart Mill's defense of liberty of expression, which he regards as essential to the mental development of mankind. See, e.g., MiLl, supra note 151, at 32-33.

270 See Emerson, supra note 25, at 879-81. 
tion under the First Amendment than freedom of speech and press. ${ }^{271}$ Second, the means by which individuals express their emotions and ideas are not limited to oral and written language, but also include symbolic action. Therefore, such action should also receive protection under the First Amendment.

While both of these positions are generally accepted, a third is somewhat more controversial. Many courts and theorists equate "speech" for First Amendment purposes with communication to others. ${ }^{272}$ If a basic aim of the First Amendment is to protect individual personality, however, then it should also extend to solitary forms of expression, such as writing in a diary or lighting a candle in memory of a loved one. Such an act is an exercise of the freedom to determine one's inner life, and may be no less important than communication as a form of self-expression and self-realization. ${ }^{273}$

Thus far, I have focused on the right of active self-expression, the freedom most immediately suggested by the constitutional language. But the First Amendment's protection extends to two other rights as well. The first is to the right to refrain from expression. In discussing external rights, I said that, as a general matter, liberty should be understood as the power to either act or not act according to one's own choice. For this reason, the right to free speech also included the right not to speak. ${ }^{274}$ The same is true of freedom understood not in physical terms but as a right of personality. The inner self is inviolable; any intrusion into it, or attempt to expose it to others against its will, does violence to this inner freedom. This is the basis of the Supreme Court's holding in West Virginia State Board of

271 One way to reconcile this position with the constitutional text is as follows. When one aspect of a right is more controversial than another, a statutory or constitutional provision protecting that right may be drafted in such a way as to expressly refer only to the former. In interpreting such a provision, it is reasonable to hold that if it was intended to protect the more controversial aspect, it was also intended to protect the less controversial one.

We can understand the First Amendment's application to freedom of thought in these terms. In protecting free speech, the First Amendment did not mean to leave a person's inner thoughts unprotected. Instead, this right was hardly controversial in the late eighteenth century-even those who would allow substantial limitations on speech recognized that liberty of thought and belief were inalienable rights. See supra note 70 (discussing Blackstone's view). It is therefore reasonable to hold that if the First Amendment protects freedom of speech, a fortiori it also protects freedom of thought. For an analogous argument in a statutory context, see Robert A. Gorman \& Mathew W. Finkin, The Individual and the Requirement of "Concert" Under the National Labor Relations Act, 130 U. PA. L. REv. 286 (1981).

272 See, e.g., Ely, supra note 180, at 1497; Scanlon, supra note 169, at 206; Texas v. Johnson, 491 U.S. 397, 404 (1989).

273 See BAKER, supra note 169, at 51-52.

274 See supra notes 231-32 and accompanying text. 
Education v. Barnette 275 and subsequent cases that compelled expression violates the First Amendment. ${ }^{276}$

Second, on the account developed here, self-expression serves to realize an individual's subjective self in the external, objective world. The concept of selfdetermination also includes a right which is the mirror image of this - a right to receive images and ideas from the external world and to use them to form one's internal self. ${ }^{277}$ Of course, this includes the right to read, watch, and listen to the expression of other willing persons. The right should be regarded as broader than this, however. Just as the right to expression included solitary activity, the right to receive should not be limited to communications from others, but should also extend to other activity by which the mind and self are formed. If the right to receive includes the freedom to view a painting of a landscape, or to read a book on plant biology, it should also include the freedom to contemplate a sunset or to examine plants in a laboratory. The right to receive therefore encompasses a general freedom of inquiry and observation, as well as a right to receive communications from others. Conversely, the right to form the self includes at least some right to choose what one does not wish to be exposed to. ${ }^{278}$

Up to this point, I have emphasized the value of First Amendment activities for forming or expressing the self. It is important to recognize, however, that those activities also may have instrumental value in promoting the purposes of individuals, organizations, or the society. For instance, commercial speech may have value in allowing individuals to make more informed choices about goods and services. $^{279}$ Similarly, expression may have value simply for entertainment. Speech

275319 U.S. 624, 642 (1943) (holding that compulsory flag salute, by "requir[ing] affirmation of a belief and an attitude of mind," "invades the sphere of intellect and spirit which it is the purpose of the First Amendment ... to reserve from all official control").

276 See, e.g., Wooley v. Maynard, 430 U.S. 705 (1977).

277 This is one of the original meanings of "information," which referred to the "formation" of the mind through such external means as instruction. See OXFORD ENGLISH DictionARY ( 2 d ed. 1989), s.v. inform, information. For an example, see LOCKE, Two TREATISES, supra note 29 , II $\S 58$ (stating that parents have a duty to "inform the Mind, and govern the Actions" of their children until they reach the age of reason). On the recognition of a First Amendment "right to receive information and ideas," see, for example, Board of Education v. Pico, 457 U.S. 853, 866-68 (1982) (plurality opinion), and cases cited.

278 See, e.g., Public Utils. Comm'n v. Pollak, 343 U.S. 451, 467-69 (1952) (Douglas, J., dissenting). This is especially true within one's own home, see, e.g., Rowan v. United States Post Office Dep't, 397 U.S. 728, 737-38 (1970), and in areas such as the workplace where one is required to be, see, e.g., Harris v. Forklift Sys., 510 U.S. 17, 21 (1993).

279 See Martin H. Redish, The First Amendment in the Marketplace: Commercial Speech and the Values of Free Expression, 39 GEO. WASH. L. REV. 429, 432-34 (1971). 
of this kind also has a claim to First Amendment protection. Of course, that does not mean it may not be regulated insofar as it affects the rights of others. ${ }^{280}$

\section{b. Free Speech and the Rights of Others}

Although it includes solitary activities, the notion of self-expression clearly would be incomplete if it did not also extend to communication with others. Why should this be the case, however? Self-realization theories of free speech have not always explored this question, or recognized its crucial importance for the shape of an adequate theory of the First Amendment. After all, when freedom of speech is understood in terms of self-realization, it appears to be an essentially self-regarding activity. If that is so, is there any reason why this activity must involve others?

The answer would seem to lie in the basic notion of self-realization. ${ }^{281}$ Human beings cannot be content with being merely potential, but have a drive to realize themselves, to give their subjectivity an existence in the world. One way they do this is by asserting themselves in relation to the physical world, for example, by acquiring property. As a mere thing, however, property is inadequate as an expression of the self. In order to fully realize themselves, individuals must do so in a medium that is adequate to the selves they are trying to express. And this can only be other selves. For this reason, individuals cannot be satisfied with merely having their own solitary thoughts and feelings, but also feel a need to express themselves to other persons.

In this way, individuals realize themselves not only on their own, but also in and through the consciousness of others. This raises the possibility, however, that an individual will use others as a mere means to her own self-realization, contrary to the Kantian injunction against treating persons solely as means rather than as ends in themselves. ${ }^{282}$ If this is not to occur, the right to self-expression must be exercised in a way that is consistent with respect for other persons and their own rights of self-realization. Speech transgresses this principle when it infringes the right to personality itself, the right to self-expression, or the right to reputation.

\section{Injuries to Personality}

\section{a. Substantive Injury: Intentional Infliction of Emotional Distress}

In Part II.B, we saw that personal security can be understood in terms of the connection between the self and the body. ${ }^{283}$ In a similar way, rights of personality can be understood in terms of a relationship between the self and itself. In everyday language, we speak of a person gathering his thoughts, making up his mind,

280 Moreover, some speech, such as commercial advertising, might also be subject to broader regulation for the public good. See supra note 227.

281 The argument of this paragraph is derived primarily from HEGEL, supra note 208, $\S \S 33 \mathrm{~A}, 71,73,112$.

282 See KAnT, Foundations, supra note 208, at *429.

283 See supra notes 235-37 and accompanying text. 
getting a grip on himself, and so on. These expressions describe the self in both active and passive terms - both as the subject that determines, and as the object that is determined. 284

This distinction allows us to understand the structure of the right to one's personality. Just as personal security was based on a two-fold relationship between the self and the body, the right to personality is based on a like relationship between the free, autonomous self, on one hand, and the determined self on the other. First, the unity between these two sides of the self is even closer than that between the self and the body. And second, the autonomous self asserts a right over the determined self - a right to determine one's own thoughts and emotions, to shape one's inner life. It follows that, in both of these respects, an injury to the determined self — to the individual's mind and feelings — constitutes a wrong against autonomous personality.

With this background, we can describe in more precise terms what makes intentional infliction wrongful. ${ }^{285}$ By causing severe mental or emotional distress (or in some cases lasting psychological damage), such conduct inflicts harm to the determined self, and thereby violates the rights of the autonomous self. In this way, intentional infliction constitutes a substantive injury to personality, analogous to harmful battery against the body. ${ }^{286}$

284 In drawing this distinction, it is important to recognize that these two different aspects do not necessarily represent separate parts of the self. People shape their own thoughts and feelings, which may then in turn enter into further acts of selfdetermination. Thus, it is more useful to characterize the two aspects as two different ways of viewing the self, rather than as distinct parts of the self.

285 The category of substantive injury to personality includes other wrongs such as negligent infliction of emotional distress, criminal harassment, and racial and sexual harassment under Title VII. For sake of simplicity, my discussion here will focus on intentional infliction, which is one of the most important ways in which the law protects against such injury.

286 Intentional infliction is a rather abstract, undifferentiated category which covers a multitude of sins. To fully understand this wrong, it would be valuable to explore the various kinds of emotions that it affects, and their importance to personality. In some cases, the harm is to the victim's natural feelings - those she has as a merely existing being, such as the fear of injury in Siliznoff, see supra notes 255-56 and accompanying text. In other cases, the wrong is to moral feelings such as self-respect, or the awareness of one's identity as a free being with intrinsic worth. See generally DigniTy, Character, AND Self-Respect (Robin S. Dillon ed., 1995). This injury occurs in those cases of intentional infliction that are marked by insult and humiliation; I shall return to them in Part IV.A, in discussing whether the First Amendment should protect insulting speech. In still other cases, the injury is to one's social feelings, such as the plaintiff's attachment to her husband in Wilkinson. No doubt there are also other kinds of emotions affected by intentional infliction, and many situations may involve more than one. Identifying the various species of emotional injury may enable us to distinguish between those injuries that are merely idiosyncratic or unjustified, and those that have a solid basis in the nature of personality. 
Intentional infliction may also cause injury in a second way, by undermining the relationship between the autonomous and the determined self, the power of the former over the latter. In Wilkinson, ${ }^{287}$ for example, the defendant's act not only caused the plaintiff to suffer intense grief and anxiety, but also for a time shattered her self-possession and ability to control her own thoughts and feelings. Although it is neither possible nor desirable to have complete control over one's emotions, a minimal amount of self-control is essential to free personality. At least in some cases, intentional infliction undermines this capacity for a time.

As with other rights of personality, the common law was slow to protect the interest in emotional tranquillity as such. The right was first recognized in the context of assault. ${ }^{288}$ In addition, where an individual had suffered some other tort, such as battery or trespass, he was often allowed to recover damages for emotional distress as well. ${ }^{289}$ During the present century, courts came to recognize intentional infliction of emotional distress as an independent cause of action. Under the Restatement formulation, liability is imposed for "extreme and outrageous conduct" that intentionally or recklessly causes an individual to suffer severe emotional distress. $^{290}$

Like most injuries to personality, intentional infliction can take the form of conduct, such as a life insurance company's bad-faith refusal to pay a valid claim by beneficiaries who are distraught and financially desperate. Because intentional infliction is essentially an injury to consciousness, however, it often takes the form of expression. This brings it into potential conflict with the First Amendment.

For the liberal tradition, rights and liberty are ultimately grounded in reason, which is the capacity that makes self-determination possible. ${ }^{291}$ As reasonable beings, human beings have a fundamental interest in the discovery of truth, a process that requires exploration of conflicting perspectives and ideas. ${ }^{292}$ It follows that individuals have no right to be free from emotional distress caused merely by ideas with which they disagree. In addition to being inherent in the right against emotional distress itself, this limitation is necessary to reconcile that right with freedom of speech and thought.

This does not mean, however, that the right against emotional distress can never be violated by speech, as the example of Wilkinson makes clear. Instead, the distinction that must be drawn is one between ideas, which are protected by the First Amendment, and personal abuse or other attacks on personality, which should not be. In many cases this distinction will be clear, while in others it will

\footnotetext{
287 See supra notes 260-61 and accompanying text.

288 See I. de S. v. W. de S., Y.B. Lib. Assis. f. 99, pl. 60 (1348).

289 See, e.g., Bouillon v. Laclede Gaslight Co., 129 S.W. 401, 402 (Mo. App. 1910).

290 Restatement, supra note 241, § 46.

291 See supra note 34 and accompanying text (discussing Locke); see also KANT, Foundations, supra note 208; KANT, MEtAPhysics OF MORALS, supra note 208, at *214.

292 See infra Part II.E.
} 
be more difficult to draw. We shall return to this problem in Part IV in discussing whether insults and hate speech should be protected by the First Amendment.

\section{b. Formal Injury: Invasion of Privacy}

The category of injuries to personality is not limited to the infliction of emotional distress. Suppose that $A$ repeatedly makes anonymous, graphically obscene telephone calls to $B$. If $B$ suffers severe distress, she may well be able to recover for intentional infliction. Even if she avoids such distress, however, the calls nevertheless constitute a serious and wrongful intrusion into her inner life.

As this example suggests, the right to personality is analogous to that of personal security in the external sphere. As we have seen, personal security includes not only a right against substantive harm to the body, but also a formal right to bodily integrity. ${ }^{293}$ Similarly, the right to personality is not limited to freedom from substantive harm (emotional distress or psychological damage), but also includes a right to the formal integrity or inviolability of the self, that is, its immunity from external interference. Just as the right to bodily integrity was violated by unauthorized touching that was inconsistent with personal dignity, so the right to an "inviolate personality" is infringed by conduct that impermissibly crosses the boundary that separates the self from others, thereby treating it in a way that is inconsistent with its dignity and integrity.

Many violations of this formal right of personality fall under the rubric of invasion of privacy. ${ }^{294}$ Privacy may be understood as the right to maintain the integrity of one's personality and inner life by preserving the boundary that separates them from other persons. ${ }^{295}$

The philosophical basis of privacy, and its relationship to free personality, may be described as follows. ${ }^{296}$ In the sphere of external right, the individual was oriented toward the outside world. In the realm of personality, on the other hand, the self turns inward, withdrawing from externality into itself. In so doing, it separates itself from other selves and creates a boundary between itself and them-a division that is much deeper than that between physical bodies. In this respect, privacy is rooted in negative freedom, both internally and in relation to other persons.

293 See supra notes 240-41 and accompanying text.

294 In Part IV.A infra, I shall argue that profound insults also violate the dignity and integrity of personality.

${ }^{295}$ For an illuminating history of privacy and related issues in modern American life, see Rochelle Gurstein, The RepeAl of Reticence (1996).

296 For valuable discussions of the nature of privacy, see StANLEY I. BENN, A THEORY OF Freedom 264-305 (1988); KANt, Metaphysics of Morals, supra note 208, at *47172; Nomos XIII: Privacy (J. Pennock \& J. Chapman eds., 1971); Robert C. Post, The Social Foundations of Privacy: Community and Self in the Common Law Tort, in Constitutional Domains, supra note 27, at 51-88; Alan Westin, Privacy AND Freedom (1967); Charles Fried, Privacy, 77 YAle L.J. 475 (1968). The account that follows draws on Hegel's discussion of subjectivity in the Philosophy of Right. See HEGEL, supra note 208, §§ 94A, 105-41. 
Privacy is not merely negative, however. By withdrawing into itself, the self frees itself from externality, and thereby attains the capacity for self-determination. This includes the freedom to direct one's own thoughts and actions, within the boundary that separates the self from others. Thus privacy creates an inviolable realm of subjectivity within which individuals can develop a rich inner life. This is the positive dimension of privacy, and its connection with positive freedom.

For these reasons, privacy is a fundamental right. Indeed, a minimum of privacy may be essential to the very existence of human personality. ${ }^{297}$ A person differs from a thing in not being merely external, but in having an inward dimension as well. It is this distinction between internal and external that makes it possible for human beings to be autonomous, that is, to be determined by their own inner selves. Without inwardness, people would be mere objects vulnerable to determination by external forces, or to manipulation or domination by other persons. ${ }^{298}$ Privacy safeguards the inwardness necessary for autonomous personality.

The right to privacy has two facets. The first is the liberty to determine one's own thoughts, feelings, and inner life in general, free from unauthorized intrusion or interference by others. The second is the right to determine what aspects of one's private life should be revealed to others. These two sides of privacy perform complementary roles in maintaining the boundary between the self and others: the former prevents incursions into the personal sphere, while the latter protects that sphere from involuntary exposure to the outside world. ${ }^{299}$

The first dimension of privacy is protected by section $652 \mathrm{~B}$ of the Second Restatement of Torts, which imposes liability on one who "intentionally intrudes, physically or otherwise, upon the solitude or seclusion of another or his private affairs or concerns, ... if the intrusion would be highly offensive to a reasonable person." 300 Acts of this sort (such as obscene or harassing telephone calls) have a wrongful impact on the plaintiff's consciousness, interfering with her subjectivity

297 For an insightful discussion on which this paragraph draws, see Harry M. Clor, Obscenity and Freedom of Expression, in CENSORSHIP AND FREEDOM OF EXPRESSION 97, 102-04 (Harry M. Clor ed., 1971).

298 Thus Hamlet, in resisting the efforts of Rosencrantz and Guildenstern to manipulate him into betraying his private thoughts, exclaims:

Why, look you now, how unworthy a thing you make of me. You would play upon me, you would seem to know my stops, you would pluck out the heart of my mystery, you would sound me from my lowest note to the top of my compass....

$[\mathrm{D}] \mathrm{o}$ you think I am easier to be played upon than a pipe?

WiLliam SHAKESPEARE, HAMLET, act III, sc. ii, 11. 354-61 (Harold Jenkins ed., Arden ed., Routledge 1989).

299 In addition to intrusion and exposure, American law treats two other interests under the heading of privacy: the right not to be publicly portrayed in a false light, see RESTATEMENT, supra note $241, \S 652 \mathrm{E}$, and the right against use of one's name or likeness for purposes to which one has not consented, see id. $\S 652 \mathrm{C}$. As I explain below, these interests are better understood as part of the right to one's image or persona. See infra notes 327-29 and accompanying text.

300 RESTATEMENT, supra note 241, § 652B. 
in much the same way that offensive battery interferes with her body. In this way they violate the integrity and dignity of personality, and interfere with the individual's freedom to determine his own inner life.

Intrusion need not have a direct impact on the victim's consciousness, however. In Hamberger v. Eastman, ${ }^{301}$ a landlord surreptitiously installed listening equipment in his tenants' bedroom, and eavesdropped on their sexual relations for more than a year. ${ }^{302}$ Although the tenants were unaware of this conduct, it nevertheless intruded upon the most intimate aspects of private life. It therefore constituted a violation of personality, in the same way that offensive battery can be committed (even without the victim's knowledge) by making contact, not with the body itself, but with an object so closely connected with it as to be regarded as an extension thereof. ${ }^{303}$

In addition to intrusion, Hamberger illustrates the second form of invasion of privacy, exposure. In some cases, the victims' private life is exposed only to those who have intruded into it, like the landlord in Hamberger. ${ }^{304}$ In other cases, the wrong takes the form of revealing it to others or to the public in general. This would be the case if the defendant in Hamberger had been a reporter for a tabloid television program which had then played recordings of the plaintiffs' sexual activity on the air. Such cases are governed by section 652D of the Restatement, which imposes liability on one who "gives publicity to a matter concerning the private life of another," if the matter "is of a kind that would be highly offensive to a reasonable person" and "is not of legitimate concern to the public." 305

In the case of intrusion, the injury involved invasion of the subjective realm by the outside world. Conversely, the harm of exposure is that it transforms inward subjectivity into a mere object for others. The point is well illustrated by the facts of Boyles v. Kerr. ${ }^{306}$ Boyles took Kerr, whom he had been dating for several months, back to his room and had sex with her. Unknown to Kerr, Boyles and his friends had previously hidden a video camera in the closet and set it to record anything that should take place. Boyles later screened the videotape for his college

301206 A.2d 239 (N.H. 1964). For an exploration of this case from a different perspective, see Post, supra note 296, at 52-59.

302 See id. at 239-40.

303 See Restatement, supra note $241, \S 18$, cmt. c.

304 The fact that intrusion and exposure frequently coincide tends to blur the difference between them. The two wrongs are conceptually distinct, however, and each is capable of occurring without the other. Thus, obscene telephone calls are an instance of intrusion that may involve little or no exposure of the victim's private life, while a spouse who sells an intimate video of the honeymoon to a tabloid television program may cause exposure without having committed a wrongful intrusion. In a broader sense, however, freedom from intrusion and exposure are simply two sides of the basic concept of privacy, the right to protect one's private life by preserving the boundary between oneself and others.

305 Restatement, supra note $241, \S 652 \mathrm{D}$.

306855 S.W.2d 593 (Tex. 1993). The facts in this paragraph are taken from id. at 594. 
fraternity brothers. Word of the tape soon spread both at Boyles's school and at the university that Kerr attended.

Boyles is a classic example of invasion of privacy through exposure of private life. ${ }^{307}$ The injury of objectification through exposure can be seen on three distinct levels. First, as discussed previously, an individual's body is not merely a physical organism but also the outward side of the self. There are some aspects and functions of the body, however, in which the physical side of human beings is especially prominent. This is true of sexual activity in particular. Sex can be intensely personal, revealing a person's deepest feelings; yet it also reflects the side of human beings that is shared with other animals. In order not to be seen solely in this light, people often desire to shield their sexual behavior from the view of outsiders. $^{308}$ In Kerr's case, the videotape was shown to people who had no interest in or regard for her as a person. In this way, she was stripped of the dignity of personality and reduced to the status of a mere body.

On a second and deeper level, we can see the wrong in Boyles as the exposure not of the body, but of the self. Those who watched the videotape were enabled to gain access to Kerr's most intimate feelings without her consent. Again, the result was to transform her subjectivity into an object for the enjoyment of others. Third, the videotape was made and shown to others without Kerr's knowledge or agreement. In this way, the conduct denied her the respect due to an autonomous individual. $^{309}$ Of course, all of these wrongs, which were committed without her awareness, were greatly intensified when she discovered what had been done.

Boyles thus exemplifies the injury of exposure on three different levels: as a wrong to the body viewed as the external side of the self; as an injury to the feelings of the determined self; and as disrespect to the self as an autonomous person. In all of these ways, exposure transforms subjectivity into a mere object that others can treat as they like.

The wrongfulness of exposure can be understood not only in terms of privacy, but also in relation to self-expression. To have value for self-realization, speech must be freely chosen by the self. ${ }^{310}$ Coerced expression, like that in the flag salute cases, not only lacks this value, but also does violence to the autonomy and

307 By setting up the video camera and recording the encounter, Boyles and his friends also committed the tort of intrusion into Kerr's private life. This intrusion may be less obvious than in Hamberger, because the conduct took place in Boyles's own room. But Boyles's right to privacy gave him no right to infringe Kerr's. Although Kerr consented to have sex with Boyles, and waived her privacy to that extent, she did not consent to be videotaped. Thus the videotaping exceeded the scope of her consent and constituted an intrusion into her personal life.

308 See Harry M. Clor, Obscenity And Public Morality 224-27 (1969); Gurstein, supra note 295, at 58-59.

309 Cf. Anita Bernstein, Treating Sexual Harassment with Respect, 111 HARv. L. REV. 445 (1997) (exploring the ways in which sexual harassment constitutes a denial of respect).

310 See BAKER, supra note 169 , at 54. 
dignity of the self. 311 Thus the right to self-expression includes the capacity to determine whether, how, and to whom one wishes to express oneself. In this way, the right against unauthorized publicity can be understood as a right to decide for oneself whether one's private thoughts, feelings, and actions should be revealed to others.

\section{c. Injury to Social Personality: Defamation, "False Light," and} Misappropriation of Name or Likeness

Leading commentators in the natural rights tradition, such as Blackstone and Kent, held reputation to be a fundamental right. ${ }^{312}$ Yet they had some difficulty in explaining the nature of this right. Their works classified reputation as an element of personal security, although it seems quite different from the other rights in this category (life, limb, body, and health). ${ }^{313}$ Moreover, the only justification they offered for this right was an instrumental one. As Blackstone put it, "reason and natural justice" require that reputation be protected, "since without [this] it is impossible to have the perfect enjoyment of any other advantage or right." 314 For example, to accuse an individual of a crime might subject him to prosecution; to assert that he had a loathsome disease might "exclude him from society"; to impugn his professional skill or integrity might endanger his livelihood. ${ }^{315}$ On this view, reputation deserves protection less for its own sake than because of its relation to other rights or interests.

This difficulty in accounting for the right to reputation may be traced to the basic assumptions of classical natural rights theory. As we have seen, that theory conceived of rights largely in external terms. Moreover, it focused on what Blackstone and Kent called "absolute rights"- those that inhered in individuals as separate and independent beings, rather than as members of society. ${ }^{316}$ It is hardly surprising, then, that the classical theory would have difficulty with reputation, a right that is rooted in personality and that has an important social dimension.

By the early nineteenth century, some writers were characterizing reputation in less instrumentalist terms. As the Jeffersonian jurist St. George Tucker expressed it, injuries to reputation were, "to a man of sensibility, and of conscious integrity, ... the most grievous that can be inflicted." 317 On one hand, this view looked back to an older conception of reputation as honor, ${ }^{318}$ while on the other it anticipated a growing recognition of the value of individual personality. Modern

\footnotetext{
311 See supra notes 275-76 and accompanying text.

312 See 1 Blackstone, supra note 50 , at *129,*134; 2 JAmES Kent, COMMENTARIES ON AMERICAN LAW *16.

313 See 1 Blackstone, supra note 50, at *129.

314 Id. at $* 134$.

3153 id. at $* 123$.

316 See 1 Blackstone, supra note 50 , at *123; Kent, supra note 312 , at *1.

317 Tucker, supra note 114 , at 28.

318 See Robert C. Post, The Social Foundations of Defamation Law: Reputation and the Constitution, 74 CAL. L. REV. 691, 699-707 (1986).
} 
thought also stresses the social context of individual rights. Against this background, we may be able to sketch a deeper and more satisfying account of the right to reputation, one that regards it as having intrinsic as well as instrumental value.

The starting point is to recognize that individuals relate to one another only through the images that they have of each other. We have no direct or immediate access to other selves: our knowledge of them depends on the way they appear to us. This is not to say that we are incapable of knowing others as they really are; it is merely to say that any such knowledge must be derived from our perceptions of them. ${ }^{319}$

A person's image includes not only her name and appearance, but also her reputation, that is, what others say and think about her. In turn, reputation is a function of both (1) an individual's own character and activity, and (2) the way these are viewed by others. A person's actions implicitly or explicitly express her self, revealing her character, thoughts, and emotions. These actions make an impression on others who are affected by them. The latter interpret these actions as reflecting back on the self; they attribute the actions, as well as the thoughts and feelings that they appear to express, to the actor. The sum of what is imputed to an individual in this way constitutes her reputation.

Image or reputation is not a mere representation of the self, however. Because people interact only on the basis of their perceptions of one another, an individual's image may be said to constitute her social identity, or her self in relation to others. Indeed, this is the root meaning of persona - a Latin term which originally referred to the mask worn by an actor, and hence came to mean the character in which an individual appears to others. ${ }^{320}$

In addition to an internal self, then, an individual has an external, social self or image. These two forms of personality are not simply distinct, however. From the individual's own perspective, his image is or should be an expression of his inner personality. Likewise, other people identify their image of a person with the person as he really is. And this has a reflexive effect on the subjects themselves, who have a strong tendency to internalize the view that others hold of them. ${ }^{321}$ In all these ways, the internal and external sides of personality come to be joined.

319 Of course, this point holds not only for our knowledge of persons, but also for our knowledge of other objects that exist in the world: we lack direct intuitive knowledge of them, and are capable of knowing them only through the way they appear to us. See Locke, EsSAY, supra note 33, bk. II. As I argue below, the difference between our knowledge of persons and of inanimate things is that the latter are merely passive objects for our observation, whereas the former are autonomous subjects who determine, in part, the image that we have of them.

320 See OXFORD ENGLish DictionARY, supra note 277, s.v. person, persona.

321 I do not mean to imply, of course, that individuals have no choice but to accept the image that others hold of them. In order to interact with others, however, a person must either accept this image, make an effort to change it, or become resigned to the existence of a dichotomy between her self-image and how she is viewed by others-a particularly deep form of personal and social alienation. 
Thus there is a certain unity between the self and its image, just as there was between the self and the body in the sphere of external rights. More-over, the self asserts a claim to its image, for it is only through this image that it is capable of interacting with others and thus fully realizing itself. It follows that one has a right to one's image, including one's reputation. This right has two elements. Negatively, it consists in a right not to have actions or characteristics falsely imputed to oneself. $^{322}$ Positively, it is the right not to be deprived of the image that one has legitimately acquired through interaction with others.

The right to image and reputation is partly internal and partly external to personality. On one hand, image is an aspect or dimension of the self; on the other hand, it has an outward existence in the minds of others. ${ }^{323}$ In the latter respect, it resembles the right to property, which also relates to things external to the self.

This discussion also points to the limits of the right to reputation. Because it exists in the minds of others, reputation is a function not only of the individual herself, but also of the way that others view her. The very concept of reputation supposes that others have a right to form impressions and opinions of a person, insofar as they are affected by her.

Defamation injures an individual's reputation by falsely representing her character or actions in a way that lowers her in the esteem of others, either by negative accusations or by disparaging the positive reputation that she has acquired. Defamation constitutes an intrinsic wrong to personality, and may instrumentally harm rights and interests of the kind that Blackstone discusses. ${ }^{324}$ Defamation is wrongful only if it is false, however, because one has a right to reputation only to the extent that it accurately reflects the self.

In causing harm to reputation, defamation is analogous to the other substantive injuries that we have explored, such as harmful battery and intentional infliction of emotional distress. But reputation also has a dignitary side. As we have seen, reputation is in part a reflection of the self. In this respect, there is a fundamental distinction between the images that we form of persons and those we form of things: the latter are merely passive objects that human beings are free to visualize as they please, while the former are autonomous subjects with some claim to shape the way others view them. ${ }^{325}$ To falsely represent an individual's character or ac-

322 Kant characterizes this as the right to be held "beyond reproach (iusti), since before [one] performs any act affecting rights [one] has done no wrong to anyone." According to Kant, this is part of the innate right to freedom. KANT, METAPHYSICS OF MORALS, supra note 208, at*237-38. My formulation is somewhat broader than this, for it includes not only accusations of actions contrary to right, but also other imputations which injure an individual's reputation or (as I shall explain below) represent her in a false and highly offensive light.

323 See G.W.F. Hegel, Lectures on Natural Right and Political Science $§ 45$, at 97 (J. Michael Stewart \& Peter C. Hodgson trans., 1995) (discussing honor in these terms).

324 See supra note 315 and accompanying text.

325 See TRIBE, supra note $120, \S 15-16$, at 1389-90. 
tions for our own purposes is to treat him as a mere object rather than an active subject, thus infringing the dignity inherent in personality.

This account of reputation recalls our earlier discussion of privacy. ${ }^{326}$ Both rights serve to protect the self from improper forms of objectification. Within the bounds of the right to privacy, an individual is free to develop her own subjectivity without intrusion from or exposure to the outside world. By contrast, reputation is concerned not with the inner self but with its outward, social dimension. In this regard, a person has no right to be free from the observation and judgment of others. The right to reputation does not preclude this, but rather aims to protect individuals from being reduced to the status of mere objects, rather than also being viewed as autonomous subjects. In short, the right to privacy creates an inner realm within which the self may not be viewed as an object at all, while the right to reputation regulates the manner in which the image of the self is constructed in the social realm.

In exploring other rights, we saw that they could be violated not only in a substantive but also in a formal way, by infringing their dignitary aspect. ${ }^{327}$ The same is true here. Falsely representing a person's character or actions might not cause substantive harm to reputation in a particular case, but would nevertheless violate her dignity as an autonomous being. This is the subject of the tort known as "false light," which consists of misrepresenting an individual before the public in a way highly offensive to a reasonable person. ${ }^{328}$ Although "false light" is often classified as a form of invasion of privacy, it is best understood as protecting the dignitary dimension of reputation.

Finally, the right to social personality is also violated when one's name or likeness is appropriated by others without one's consent. Such conduct may also violate the right to privacy, by involuntarily exposing one's self to the world. ${ }^{329}$

326 See supra Part II.C.2.b.

327 See, e.g., supra notes 240-41 and accompanying text (discussing offensive battery).

328 See RESTATEMENT, supra note $241, \S 652 \mathrm{E}$.

329 See id. $\S 652$ C. For example, in one leading case, a young woman had her portrait taken by a photographer, who later sold the photograph without her knowledge or consent to a company which used it to advertise their products. See Roberson v. Rochester Folding Box Co., 64 N.E. 442 (N.Y. 1902). After the New York Court of Appeals denied recovery, see id., the legislature responded by enacting the first modern privacy law. See Prosser and Keeton on the Law of Torts 850-51 (W. Page Keeton et al. eds., 5th ed. 1984) [hereinafter Prosser AND KeEton]. Other states protect against misappropriation of name or likeness as a matter of either statutory or common law. See id. at $851-52$.

In many cases, such as Roberson, the plaintiff's name or likeness is used in such a way that she appears to endorse the defendant's product or other purposes. In such instances, the defendant's conduct also violates the plaintiff's right to self-expression, by falsely representing her as expressing a certain view. 
[Vol. 78:1275

\section{A Response to Some Objections}

In the previous section, I argued that in addition to justifying freedom of expression, the concept of individual self-determination gives rise to a variety of other rights, including reputation, privacy, and freedom from infliction of emotional distress. These rights are no less essential to self-realization than is free speech itself.

From a civil libertarian perspective, one might object that the law cannot properly protect these "rights of personality" because they are merely internal and subjective. The power of government consists of external force, and this force can legitimately be used only to regulate outward action that affects the external rights of others, not to control people's inner lives, such as their thoughts and beliefs. 330 Moreover, the objection continues, injuries to personality are merely subjective- harms that exist only in an individual's mind, and which for this reason are incapable of any objective definition or proof. To allow regulation on this basis would violate the cardinal First Amendment principle that speech may not be restricted merely because others find it offensive, and would open the door to "boundless subjectivity" in determining what speech should be restricted. ${ }^{331}$

I fully agree that the coercive power of law applies only to external interaction, and cannot rightfully extend to the internal realm of thought and belief. It is crucial to recognize, however, that the terms "internal" and "external" are relative: nothing is either "internal" or "external" in an absolute sense, but only in relation to something else. For this reason, determining when laws legitimately regulate external interaction and when they improperly intrude into the internal sphere requires a more complex analysis than the objection suggests.

At the core of the internal realm lies the individual's ability to determine his own thoughts, beliefs, and feelings. Because these are wholly internal to the individual and directly affect him alone, they are entirely beyond the external power of the state.

In contrast, the expression of one's thoughts and feelings to others is a kind of external interaction, which affects other individuals as well as oneself. ${ }^{332}$ Nevertheless, insofar as the communication involves only a willing speaker and a willing listener, and does not affect the rights of third persons (as in cases of defamation and invasion of privacy), it may be regarded as internal to the relationship between speaker and listener, though it is external to each viewed as a separate individual.

330 See, e.g., LOCKE, TOLERATION, supra note 32, at 26-27.

331 Franklyn S. Haiman, SPEECh AND LAW IN A FreE Society 152 (1981) (criticizing the tort of intentional infliction of emotional distress because of "the boundless subjectivity that inheres in judgments like 'outrageousness"').

332 Recognizing this point, John Stuart Mill observes that the expression of opinions "belongs to that part of the conduct of an individual which concerns other people." MiLL, supra note 151, at 13 . He argues, however, that liberty of expression, "being almost of as much importance as the liberty of thought itself, and resting in great part on the same reasons, is practically inseparable from it." $I d$. Nevertheless, he makes clear that freedom of speech is limited by the rights of others. See id. at 53. 
Government may not properly intrude into this relationship, with regard to which the government is an outsider, an external force.

The case is very different, however, when a speaker seeks to communicate with an unwilling listener. Here, there is no voluntary relationship in relation to which the speech can be considered internal. Instead, the interaction is simply an external one. That it is external does not, of course, necessarily make it wrongful. But when expression is not merely directed to an unwilling listener, but also violates her rights, the speech amounts to - and is experienced as - an external attack. This brings it within the legitimate sphere of government, whose function is to protect individuals from such assaults.

But are such attacks capable of inflicting harm to personality? Insofar as the self is purely internal, it cannot suffer injury from without. Yet the self also has a dimension that relates to and interacts with the outside world. In addition to the connection that it has with its own body and life, the self forms attachments to other persons and objects. Actual or threatened injury to something that is closely connected with the self may inflict serious harm to the mind and feelings.

It is sometimes said that the self cannot suffer such harm involuntarily. Bodily injury may be inflicted against a person's will, and the same is true of mental harms that flow from the noncommunicative aspects of an act (such as the screeching of fingernails on a blackboard). By contrast, harm caused by the content of expression-what Judith Jarvis Thomson calls "belief-mediated distress" 333 — can occur only if one listens to, understands, and accepts what the speaker is saying. ${ }^{334}$ And this depends on the listener's will. It follows that one can suffer such harm only if one wills to, and voluntary harms do not constitute a wrong.

This objection is successful in showing that some reactions to speech or conduct should not be regarded as injuries. The objection is clearly too broad, however, as Wilkinson shows. ${ }^{335}$ Surely the shock and grief provoked by sudden news of a spouse's death or serious injury will generally be beyond one's control. Thus, belief-mediated distress is not always voluntary.

The notion that belief-mediated distress does not constitute an injury might be based on a different notion - not that the distress is subject to one's control at the time it occurs, but that one can suffer such distress only if one has previously chosen to adopt a particular belief or attitude. Once again, however, this is not always the case. For instance, the anguish suffered by one who learns that she has a terminal illness may stem from an innate desire for life, or fear of death, rather than from any attitude or belief that she has chosen to adopt.

333 ThOMSON, supra note 204, at 249-71.

334 See BAKER, supra note 169, at 55-56 ("The key quality distinguishing most harms caused by protected speech acts from most harms caused by unprotected activities is that speech-caused harms typically occur only to the extent that people 'mentally' adopt perceptions or attitudes."); C. Edwin Baker, Harm, Liberty, and Free Speech, 70 S. CAL. L. REV. 979, 989-92 (1997) (elaborating this view).

335 See supra notes 260-61 and accompanying text (discussing Wilkinson). 
Moreover, even if all attitudes were adopted voluntarily, this should not lead us to conclude that any distress connected with them does not constitute an injury. A desire for life, a belief in one's human dignity, and the love that one feels for other people are all central to self-fulfillment. Even if it were possible to "retreat to the inner citadel" and refuse to connect oneself with other persons and things, this in itself would be a great obstacle to self-realization. ${ }^{336}$ As we have seen, individuals have a drive to realize themselves through interaction with the world. ${ }^{337}$ In this way, the self forms connections with other persons and things, and thereby becomes vulnerable to harm. In doing so, individuals should not be regarded as placing themselves beyond protection against deliberate injury.

In short, personality is capable of suffering injury from without. This is especially clear in the case of invasion of privacy, which transgresses the boundary separating the self from the outside world, and defamation, which injures the outward dimension of personality.

Are the rights that I have discussed truly rights, however, or are they merely subjective interests that are not entitled to recognition and enforcement by law? These rights do relate to the subjective or internal life of the individual. But that does not mean that they are "merely subjective" in the sense of being inessential. Subjectivity is constitutive of the self; without it, a human being would not be a person. As we have seen, subjectivity is the basis of individual rights, and its realization is also an intrinsic value for individuals. Indeed, that is precisely the insight on which the self-realization theory of the First Amendment is based. And that insight applies with equal force to other rights of personality.

We can make a similar response to the assertion that recognizing rights of personality would permit "boundless subjectivity" in determining what restrictions to impose on speech. Those rights do not authorize government to restrict speech whenever some people or even a majority consider it offensive. Such offense cannot provide a valid ground for regulating expression that is internal to an individual, or to the relationship between willing speakers and listeners, because such expression by definition does not affect the rights of others. ${ }^{338}$ Similarly, speech that is addressed to the public may not be restricted merely because it offends the excessive sensibilities of some, for that too would involve restricting the speech of some people based on the merely subjective reactions of others.

But speech that is directed toward individuals with the intention of violating their rights presents a different case. Although the injury may include offense or some other emotional or mental reaction, it is not the reaction alone that is the ground for restriction, but the violation of individual rights. And because those

336 See IsAiAh Berlin, Two Concepts of Liberty, in Four EsSAYS ON LiBerTy 135-41 (1969).

337 See supra note 281 and accompanying text.

$338 C f$. H.L.A. HART, LAw, LiBerTy, AND Morality 46-47 (1963) (arguing that "[n]o social order which accords to individual liberty any value could also accord the right to be protected from distress" caused by the mere thought that others are engaging in conduct to which one objects). 
rights are not "merely subjective" but reflect fundamental principles of right, the law should be able to define them with sufficient clarity for practical purposes.

Finally, some would argue that even if expression causes harms to the subjectivity of others, it should be constitutionally protected if it furthers the speaker's own self-realization. Thus, in Human Liberty and Freedom of Speech, C. Edwin Baker observes that arguments for regulation sometimes rely on detrimental effects to others-for instance, that "publication of unsavory, libelous information damages valued reputations or invades sensitive areas of privacy," or that "harassing remarks cause emotional distress and pain."339 Baker concludes, however, that such speech should be protected on traditional civil libertarian grounds:

(1) Allowing even justifiable restrictions on expression will lead to acceptance of improper suppression. (2) The majority must respect individuals' choices about their own values and not force them to falsify their values. (3) The state must permit people to speak to express themselves and make their contribution to changing the world even if some people find the speech harmful or distasteful. ${ }^{340}$

"Both the second and the third points," he adds, are "straightforward applications of the principle that the state must respect people's integrity and autonomy." 341

As we have seen, however, while autonomy includes the right to pursue one's own self-realization, it does not confer a general privilege to violate the rights of others. Baker accepts this point in principle, holding that speech is not entitled to protection if it fails to "respect the other's autonomy and integrity as a person" or "improperly interferes with the other's rights." 342 But he largely limits this category to speech which involves violence to person or property, or which coerces or otherwise distorts the will of another (such as blackmail and fraud). ${ }^{343}$ He makes clear that this category does not extend to such rights as privacy and emotional tranquillity. ${ }^{344}$ In part, this reflects the view already discussed, that these interests are merely internal and subjective. And in part, it reflects the tendency of modern First Amendment theory to conceive of free speech issues as conflicts between individual rights and social interests. ${ }^{345}$ In the quoted passage, Baker characterizes the arguments about the injuries caused by expression not as rights-based arguments, but rather as "efficiency arguments" concerned with the impact of expression on aggregate social welfare. ${ }^{346}$ In both of these ways, Baker fails to recognize that privacy and other interests of personality are rights that have precisely the

\footnotetext{
339 BAKER, supra note 169 , at 86.

340 Id. at 87.

${ }^{341} I d$.

$342 I d$. at 56, 58.

343 See id. at 59-60.

344 See id. at 86.

345 See supra Part I.D.

346 BAKER, supra note 169 , at 87.
} 
same basis as his own account of freedom of speech - the value of individual selfrealization.

\section{Free Speech and Community}

Thus far, we have explored two dimensions of liberty-freedom in relation to the external world and in the development and expression of personality. In addition to justifying freedom of speech and thought, these two principles also support other rights such as personal security, privacy, and reputation.

External rights and rights of personality are liberties that in principle can be possessed and enjoyed by a single individual, without any necessary interaction with others. In the language of classical social contract theory, they are aspects of natural liberty, or rights that would belong to individuals even in a state of nature.

Of course, human beings live not in a state of nature but in society with others. What does liberty mean in this sphere? Society imposes limitations on individuals, and in this way may seem antithetical to freedom. A central insight of the liberal tradition, however, is that social constraints can be reconciled with selfdetermination if, and insofar as, they can be regarded as limitations that people freely impose upon themselves. ${ }^{347}$ In particular, laws made by the political community are consistent with freedom (1) formally, insofar as they result from a process of collective self-determination in which all citizens have a voice; and (2) substantively, to the extent that they are necessary to protect individual liberty or advance the common good - that is, those ends that individuals have in common and would authorize the community to pursue through collective action. According to this view, the essential purpose of society is not to restrict but to promote freedom. It does this not merely by protecting natural liberty, but also by creating new opportunities for the realization of individual capacities through social interaction, as well as by enabling people to pursue ends collectively that they could not achieve as well (or at all) on their own. ${ }^{348}$

Against this background, we can sketch what it means to be a free person in the social realm. First, and most fundamentally, it means to be a citizen or member of the community, and to be treated as such by others and by the community as a whole. ${ }^{349} \mathrm{We}$ shall return to this point in discussing the problem of hate speech. ${ }^{350}$

347 See, e.g., Locke, Two Treatises, supra note 29, II $\S 95$; JEAN-JACQUES Rousseau, The Social Contract bk. I, chs. 6, 8 (Hopkins trans.), in Social Contract: Locke, Hume, Rousseau (Ernest Barker ed., 1947); Kant, Metaphysics of Morals, supra note 208 , at $* 313-14$.

348 On law and society as expanding freedom, see, for example, LOCKE, TwO TREATISES, supra note 29 , II $\S 57$; 1 BLACKSTONE, supra note 50, at*125-26; [Thomas Tudor Tucker,] Oration in Commemoration of American Independence (1795), quoted in id. (ed. note).

349 This understanding is closely related to the etymological origins of "freedom." According to the Oxford English Dictionary, the word can be traced back to a Germanic root meaning "dear" or "to love" (and thus is related to "friend"). It came to 
Second, in a free society individuals are entitled to the two forms of liberty that we have already explored - external rights and rights of personality-subject to such regulation as is necessary to protect the rights of others and of the community. In addition to being protected by ordinary law against other individuals, such freedom, traditionally known as civil liberty, is also constitutionally safeguarded against invasion by the government itself.

Third, a free person has a claim to social liberty, or the right to form social relationships and to participate in community life. This form of freedom arises only within society. In the classical legal tradition, it is sometimes referred to as the "privileges" of society, in contrast to those "immunities" which consist in the natural liberty that individuals retain within society. ${ }^{351}$ Finally, a free person is entitled to political liberty, or the right to full and equal participation in the process by which the community governs itself and its members.

Taken together, these four elements - citizenship and the civil, social, and political rights that flow from it - define what it means to be free within the sphere of community. Only in this way can it be said that individuals remain autonomous even though they are subject to social constraint.

Just as liberty in the first two spheres provided justifications for freedom of speech, so does liberty in the realm of community. First, free speech is entitled to constitutional protection as a form of civil liberty - a rationale that applies to private as well as public speech. Second, speech plays an essential role in overseeing the use of governmental authority, preventing or exposing abuses of power and thereby protecting civil liberty against the threat of tyranny. This rationale, which was central to the eighteenth-century American understanding of freedom of speech, ${ }^{352}$ is an important theme in modern First Amendment decisions such as New York Times v. Sullivan. ${ }^{353}$

In addition to constituting a barrier against abuse of power, free speech has crucial positive value in relation to political liberty and democratic self-government. As we have seen, this value was central to Justice Brandeis's defense of free speech in Whitney v. California. ${ }^{354}$ "Those who won our independence," he wrote,

believed that the final end of the State was to make men free to develop their faculties; and that in its government the deliberative forces should prevail

have its present meaning through being applied to those members of the household who shared a bond of kinship, as distinguished from slaves. See OXFORD ENGLisH DICTIONARY, supra note 277 , s.v. free. In its origins, then, the term "free" combined the notion of liberty with that of belonging to a particular community. Although this etymology is remote from our current use of the word, we may discern a similar connection in the notion of constitutional rights as the privileges and immunities of citizenship.

350 See infra Part IV.B.

351 See, e.g., 1 BLACKstone, supra note 50 , at *129.

352 See Blasi, Checking Value, supra note 42.

353376 U.S. 254 (1964).

354274 U.S. 357, 375 (1927) (Brandeis, J., concurring); see also supra note 156-57 and accompanying text. 
over the arbitrary. They valued liberty both as an end and as a means. *** They believed that freedom to think as you will and to speak as you think are means indispensable to the discovery and spread of political truth; that without free speech and assembly discussion would be futile; that with them, discussion affords ordinarily adequate protection against the dissemination of noxious doctrine; that the greatest menace to freedom is an inert people; that public discussion is a political duty; and that this should be a fundamental principle of the American government. 355

These themes are further developed by Alexander Meiklejohn in a classic series of lectures first published in 1948. ${ }^{356}$ American government, Meiklejohn maintains, is founded on a "compact" that we have made as free and equal individuals to constitute a self-governing community. ${ }^{357}$ Freedom of speech must be protected because it is essential to democratic self-government. Meiklejohn elaborates this view by reference to the traditional town meeting, in which citizens gather to discuss and act on matters of public concern. In such a meeting, every individual "has a right and a duty to think his own thoughts, to express them, and to listen to the arguments of others. The basic principle is that the freedom of speech shall be unabridged," so that the community can reach the wisest and most fully informed decisions on the issues that come before it. ${ }^{358}$ This means that no view "shall be denied a hearing because it is on one side of the issue rather than another," or because others think it false or dangerous. ${ }^{359}$

In the nature and requirements of a self-governing community, Meiklejohn finds not only the basis of political free speech, but also its limits. Again, he makes the point in the context of the town meeting. The meeting cannot function unless its members observe certain rules of order — rules that, for example, forbid interrupting one who has the floor, or speaking abusively toward other members. Speech of this sort obstructs the deliberative process, and thus "threatens to defeat the purpose of the meeting." 360 For this reason, it is not protected by the principle of political free speech.

This highlights a crucial point about free speech as political liberty. When viewed in terms of external rights or self-realization, freedom of speech was an inherently individual right. In contrast, political free speech is best understood as a relational right - a right to interact with others in a particular way. ${ }^{361}$ As de-

${ }^{355} I d$. For an insightful reading of this opinion, see Vincent Blasi, The First Amendment and the Ideal of Civic Courage: The Brandeis Opinion in Whitney v. California, 29 WM. \& MARY L. REV. 653 (1988).

356 See MeIKLEJohn, supra note 170.

357 Id. at $14-19,27,88$.

$358 I d$. at $24,26$.

359 Id. at 26-27.

360 Id. at $24-25$.

361 This distinction between inherently individual rights and relational rights is a traditional one. Blackstone and Kent, for example, distinguish between "absolute" rights, which are inherent in individuals and would exist even in a state of nature, and 
scribed by Brandeis and Meiklejohn, it is a right to discourse with other individuals who have the same rights of citizenship and participation, and who share certain interests as a community. The right to participate in public deliberation thus carries with it a duty to respect the corresponding rights of other citizens and of the community itself.

Like the previous justifications, then, the concept of political liberty supports a right to free speech and at the same time points to limitations on that right. In the case of political free speech, these limitations are internal to the right itself. Like other freedoms, political free speech is also subject to external limitations arising from other rights, such as personal security and reputation. Because of its great value, however, political speech sometimes should be protected at the expense of other rights, as in the New York Times case.

Freedom of speech is also an element of social liberty. Communication plays an essential role in forming and maintaining social relationships. Individuals also have a right to participate in, and contribute to, the culture of the community. ${ }^{362}$ Once again, when understood in this way, free speech is best understood as a relational right to take part in shared activity. ${ }^{363}$

Finally, in addition to its role in promoting social and political ends, we should recognize the ways in which speech itself is social. When viewed as a form of external action or self-realization, expression appeared to be an essentially individual activity. In exploring the notion of self-realization, however, we observed that individuals have a strong drive to express themselves not merely through solitary activity, but also in relation to other people. This led us to conclude that the

"relative" rights, which belong to individuals "as members of society, and standing in various relations to each other." 1 BLACKSTONE, supra note 50 , at *123; 2 KENT, supra note 312 , at $* 1$. In these terms, personal liberty is an absolute right, while family and political relationships involve relative rights. To avoid misunderstanding, it should be noted that, in this traditional terminology, the terms "absolute" and "relative" refer to the nature rather than the strength of the right: although absolute rights were inherent in individuals, they were limited by the rights of others, and (except insofar as the right was an inalienable one) subject to regulation for the common good. See Steven J. Heyman, The First Duty of Government: Protection, Liberty and the Fourteenth Amendment, 41 Duke L.J. 507, 532-33 (1991) [hereinafter Heyman, First Duty].

362 See, e.g., Police Dep't v. Mosley, 408 U.S. 92, 95-96 (1972); Emerson, supra note 25 , at 883 . In some cases, participation in culture is a private activity that falls within the notion of civil liberty. For example, people may go to a movie for enjoyment with no thought of influencing the culture. On the other hand, a critic who discusses cultural trends is engaged in a more public activity that is analogous to political participation.

363 Although this section has focused on the meaning of liberty within society as a whole, it should be noted that rights of community also apply to other groups, such as families, neighborhoods, workplaces, universities, and churches. All of these communities involve interaction with others and require respect for their rights. In some cases, these rights are protected by public or private law, while in others they are governed by the internal rules or understandings of the group itself. 
right of expression must be exercised with due regard for the self-realization of others. ${ }^{364}$

If we reflect further, however, we can see that the notions of self-expression and self-realization do not fully capture the nature of speech to others. In many cases, a speaker desires not merely to express his own thoughts or feelings, but to create a condition of mutual understanding between himself and the listener. Moreover, this generally involves not one person speaking and another listening, but discourse between two or more people. In these ways, speech that seeks mutual understanding is more than merely the sum of the expression and reception of the individuals involved. Instead, such speech constitutes not simply self-expression but communication - an inherently social, relational activity. ${ }^{365}$

This social dimension is essential to many of the functions that speech performs within the sphere of community. In particular, the formation of social relationships, the development of a common culture, and democratic deliberation all depend upon the possibility of achieving some measure of mutual understanding among individuals. This social dimension is also central to the final justification for freedom of speech, its value in relation to truth.

\section{E. Free Speech and the Search for Truth}

In contrast to inanimate objects, human beings not only exist but are conscious of their existence and their relation to the natural and social world that surrounds them. This consciousness lies at the root of freedom: it is what enables human beings to be self-determining, rather than wholly determined by external forces.

In analyzing consciousness, we can distinguish between subject and object - between the conscious self and what the self is conscious of. That is not to say, of course, that the two must necessarily be different things. In the case of selfknowledge, subject and object are identical: the self that knows is the same as the object that is known. In other cases, however, subject and object are distinct. One who observes a natural object or event, for example, is not the same as that which is observed. In such cases, it is possible for consciousness either to conform with its object or to fail to do so- or rather (since this is a matter of degree) for consciousness to be more or less successful in achieving knowledge of the object.

364 See supra notes 281-82 and accompanying text.

365 See, e.g., Robin West, Toward a First Amendment Jurisprudence of Respect: A Comment on George Fletcher's Constitutional Identity, 14 CARdozo L. REV. 759, 761 (1993). I should note that, unlike West, I do not mean to suggest that free speech should be viewed as communication rather than self-expression. See id. at 761, 765. As I have argued, the First Amendment should protect solitary expression as well as that which is communicated to others. See supra note 273 and accompanying text. Moreover, the notion of self-expression naturally develops into that of communication. Speech does not cease to be expressive when it involves communication with others; on the contrary, all communication includes an element of self-expression within it. What makes communication distinctive, and irreducible to self-expression, is that the former also contains the social dimension of seeking mutual understanding. 
Consciousness may be described as true insofar as it accords with its object and false insofar as it deviates from it.

This brings us to the last traditional justification for freedom of speech and thought - that it is essential to the attainment of truth. While usually discussed in a rather general way, it is important to observe that the search for truth takes place not in the abstract, but within the different spheres that we have already explored. Thus, it includes the effort to achieve knowledge of the natural world, of the inward self, and of the social and political world. This includes not only empirical knowledge of particular things and events within these spheres, but also theoretical inquiry into the principles that govern them.

In pursuing natural, personal, and social knowledge, human beings often come to raise more ultimate questions. For example, what is the relationship between the different spheres? Can they be understood to form a larger whole? If so, what are the nature and origins of this whole? What place do human beings have within it? This is the deepest level on which the search for truth takes place, a realm that is explored in much art, literature, religion, philosophy, and science.

What value does truth have for human beings? ${ }^{366}$ To begin with, it has instrumental value in furthering their aims in other realms. Knowledge of the external world is necessary to protect one's personal safety, construct a skyscraper, or diagnose and treat a disease. Self-knowledge is vital for determining what profession to pursue, or what kind of personal or family life is most likely to be satisfying. Information about social and political matters is essential for democratic selfgovernment. And a person's religious and philosophical beliefs influence her view of what values are worth pursuing.

In addition to its instrumental importance, truth also has intrinsic value. As Milton and Mill stress, in pursuing truth human beings exercise and develop their intellectual capacities. In this way, they realize their nature as rational beings, the source of human dignity. ${ }^{367}$

In light of these values, self-determining beings would pursue truth both for its own sake and because it is necessary for effective self-determination in other spheres. For this reason, the search for truth is an essential aspect of human liberty, and thus a fundamental right. This right includes not only freedom of thought and belief, but also freedom of speech. Once again, this point can best be explored in relation to the different spheres.

As I have suggested, we can know objects only through their appearances. ${ }^{368}$ In the case of external objects, it is difficult to know how far one's perceptions are accurate, and how far they are limited or distorted by one's own biases and limitations. Thus, to attain accurate knowledge of the external world, individuals need to correlate their own perceptions with those of others. In addition to its impor-

366 For an insightful discussion of this issue, see Susan H. Williams, A Feminist Theory of Truth (Aug. 1998) (unpublished manuscript, on file with author).

367 See Mill, supra note 151, at 33-35; Milton, supra note 217, at 29-30, 37.

368 See supra note 319 and accompanying text. 
tance in everyday life, this process is central to judicial factfinding, scientific investigation, and other modes of inquiry.

The search for truth takes a very different form in the personal realm. There, instead of seeking objective perception of the external world, the individual turns inward in search of self-knowledge. For the most part, such knowledge can be derived only from introspection, not from other people. Even in this sphere, however, discussion is important in several ways. First, individuals are not always fully aware of their own thoughts and feelings. Expressing one's attitudes in a journal, or in conversation with others, is often useful not only in clarifying what they are, but also in shaping and determining what they should be. Second, individuals realize themselves not only in their inner lives but also through interaction with others. An important dimension of self-knowledge involves understanding how one's actions affect other people, and how one is regarded by them. Communication is necessary for this purpose as well. ${ }^{369}$ Finally, while every individual is unique, he also possesses many characteristics in common with others (such as being an American, a Midwesterner, a male, a musician, a Catholic, a human being, and so on). Discussion with others who share these qualities (or conversely, who differ from oneself in some of these respects) is valuable in exploring what meaning or value these attributes have and what role, if any, they should have play in one's identity.

This recognition of the social aspect of personality brings us to the social and political realm. In this sphere, the search for truth takes the form of an effort by the members of society to develop shared understandings of such matters as justice and the common good, which constitute the object of truth within this realm, just as the external world and the self did in the first two spheres.

The search for social and political truth can be understood in several different ways. Perhaps the most familiar is Justice Holmes's image of the marketplace of ideas. ${ }^{370}$ According to laissez-faire economic theory, the pursuit of individual selfinterest leads, through the workings of the market, to the greatest aggregate welfare of society as a whole. In addition, market competition results in the success of those products that best satisfy the needs and desires of consumers. Similarly, in his famous dissenting opinion in Abrams v. United States, Holmes suggests that "the best test of truth is the power of the thought to get itself accepted in the competition of the market," and that the truth which emerges in this way offers the best chance of bringing about "the ultimate good" that people desire. ${ }^{371}$

369 The attainment of self-knowledge in these and other ways is a central theme in the novels of Jane Austen. See, e.g., Jane Austen, Emma bk. III, ch. XI (R.W. Chapman ed., rev. ed. 1969); Jane Austen, Pride And Prejudice bk. II, ch. XIII (R.W. Chapman ed., rev. ed. 1969).

370 See Abrams v. United States, 250 U.S. 616, 630-31 (1919) (Holmes, J., dissenting).

${ }^{371} I d$. 
Despite its powerful impact on American thought, Holmes's marketplace metaphor is unpersuasive as an account of the search for social and political truth. ${ }^{372}$ As I have noted, individuals regarded as market participants pursue their own private good. Thus the participants in a marketplace of ideas would opt for those ideas that best promoted their own subjective interests or beliefs, and the ideas that prevailed would be those that best satisfied the subjective beliefs or interests of the greatest number of people. The outcome of the process, however, would not be an objective truth but merely an aggregate subjective belief. Although this belief might accord with the interests and views of a majority, there is no reason why it should necessarily be consistent with those of other individuals or groups. Holmes's account therefore fails to explain how the subjective perspectives of individuals and groups can be transformed into truths shared by the society as a whole.

In contrast to Holmes's economic metaphor, Justice Brandeis and Alexander Meiklejohn articulate a civic model of the search for truth. ${ }^{373}$ According to this view, public discourse is best understood as a forum within which free and equal citizens articulate competing views on justice and the public good, in a common effort to advance these ends. Only in this way can we arrive at political truth. This view does not necessarily assume that discussion will lead to consensus. Indeed, diversity of opinion is valuable so that issues may be illuminated from every perspective. $^{374}$ For the civic conception, the most important truth is not any particular outcome of the process, but rather a commitment to public discourse itself. Ultimately, this is the bond that holds the political community together and makes it possible for citizens to reach common ground.

This civic conception is superior to Holmes's marketplace of ideas in showing how it is possible to arrive at common understandings through free discussion. Yet if the marketplace model conceives of individuals in an overly private way, the civic conception may err in the opposite direction. According to Meiklejohn, individuals possess two "radically different" capacities - their role as citizens and their role as private persons. ${ }^{375}$ Likewise, he draws a fundamental distinction between public speech, which relates to the common good, and speech that is directed toward private interests. ${ }^{376}$ As Meiklejohn himself recognizes, however, in a liberal society "the public interest is not another different interest superimposed upon our individual desires and intentions," but rather "is made up out of the separate purposes of the citizens." 377 If this is so, then the search for political truth requires that we give a hearing not only to competing conceptions of the common good, but also to the particular interests of which it is composed. For this reason,

372 For some other critiques of the marketplace theory, see BAKER, supra note 169 , at 6-24; Steven H. Shiffrin, The First Amendment and Economic Regulation: Away from a General Theory of the First Amendment, 78 Nw. U.L. REV. 1212, 1281 (1983).

373 See supra notes 354-60 and accompanying text.

374 See MeIKLEJohn, supra note 170, at 27-28.

375 See id. at 80.

376 See id. at 79-80.

377 Id. at 81 . 
political speech should not be thought of as occurring solely on a public level. Instead, such speech mediates between the private and public realms by showing how the interests of particular individuals and groups should be understood as forming part of the community's good. On this revised civic conception, the search for social and political truth involves the effort to arrive at mutual understanding through the transformation of subjective views that reflect particular interests, as well as through debate over more general conceptions of justice and the common good. This view incorporates elements of both the civic and the marketplace model, with their respective views of individuals as public and private actors.

To summarize, truth exists when subjective consciousness accords with its object. In the case of external knowledge, the object is the dominant element. By contrast, in the personal sphere subjectivity is central, for the object is nothing other than the self. Social and political knowledge involves the integration of one's subjective views with those of others in order to develop common ground and mutual understanding. In each of these realms, the search for truth requires not merely individual thought but also discussion with others.

As I have suggested, we can conceive of the pursuit of ultimate meaning and value as an effort to understand the relationship between these three spheres, whether they form a whole, the nature and origins of this whole, and the place of human beings within it. Because this effort draws upon knowledge from the other spheres, the search for truth on this level also presupposes involvement by other people.

It is on this level that many of the great controversies over freedom of expression have occurred. A traditional justification for censorship was that it was necessary to prevent the spread of ideas that would undermine the fundamental truths on which a particular social order was based. Advocates of free expression such as Milton, Locke, and Mill responded in several ways. First, they argued that this justification failed to recognize the subjective dimension of truth. Even if a belief is objectively true, it will lack vital force unless it is actually held by those who profess it. ${ }^{378}$ Second, these writers asserted that the supporters of censorship were mistaken in identifying their own views, or the dominant beliefs of the society, with objective truth. Truth is not directly accessible to human beings, but can be arrived at only through the clash of conflicting perspectives. ${ }^{379}$ Finally, they implied, one of the most important truths about human beings is that they are rational beings whose dignity and fulfillment requires that they actively pursue truth. ${ }^{380}$ For all these reasons, freedom of thought and expression are necessary for the search for truth regarding ultimate meaning and value.

In exploring external freedom, personality, and community, we saw that the same values that supported freedom of expression also pointed to certain con-

378 See Locke, TOLERATION, supra note 32, at 26-27, 38; Mill, supra note 151, at 38 42; Milton, supra note 217, at 37.

379 See Locke, Toleration, supra note 32, at 27-28; Mill, supra note 151, at 44-50; MiLton, supra note 217, at 17-19, 41-46.

380 See Mill, supra note 151, at 33-35; Milton, supra note 217, at 29-30, 37. 
straints on this freedom. The same may be said of the right to pursue truth. First, this right is rooted in the fact that an individual is a subject endowed with consciousness. But this is true of other human beings as well. It follows that for an individual to view others as mere objects, rather than as subjects in their own right, would contradict the very basis on which the search for truth rests. While such a belief might reflect the subjective consciousness of an individual, it is necessarily contrary to the truth about human beings. That is not to say that such beliefs have no value at all in connection with the search for truth. ${ }^{381}$ It is merely to say that any value that they have cannot derive from the possibility that they may turn out to be true. Second, we have seen that, in many different ways, the pursuit of truth requires interaction with others. Insofar as this is true, the search for truth is a relational right, which should be exercised with due respect for other participants. In short, the truth rationale points to two limitations on the proper use of free speech: (1) the negative constraint that individuals should not view others as mere objects; and (2) the positive constraint that they should recognize others as participants in a common enterprise of searching for truth.

I should stress the limited function of these constraints. I do not mean to suggest that they provide an affirmative justification for restricting free expression. For the liberal tradition, the coercive powers of government do not extend to matters of thought or belief as such; government may never restrict expression simply because of disagreement with it or fear that it will undermine the truth. ${ }^{382}$ Instead, the role of these constraints is merely a negative one: that of showing that expression has less value for the search for truth when it either represents others as mere objects or refuses to acknowledge their own capacity to participate in this search. In some contexts, this attenuated value may mean that, where the expression violates the rights of others, it should not be protected because of its value in relation to truth. We will return to this point when we come to the question of whether and to what extent insulting speech and hate speech should receive constitutional protection. ${ }^{383}$

\section{CONFLICTS OF RIGHTS}

\section{A. A Three-Fold Inquiry}

Although freedom of speech must be exercised with due regard for the basic rights of others, that does not mean that it must always give way to those rights. In some instances, what appears to be a conflict can be resolved by adjusting the boundaries of the competing rights. Even where this is not possible, speech that

\footnotetext{
381 See, e.g., MiLl, supra note 151, at 34-44 (arguing that even false beliefs have value in promoting a clearer perception of truth).

382 See, e.g., Locke, Toleration, supra note 32, at 46 ("[T] he business of Laws is not to provide for the Truth of Opinions, but for the Safety and Security of the Commonwealth, and of every particular mans Goods and Person.”); MiLl, supra note 151, ch. 2.

383 See infra Part IV.
} 
infringes other rights is only prima facie wrongful, for it may have such value that it should be regarded as justified or privileged despite the injury it causes.

Whether one conceives of the problem in terms of "adjustment" or "privilege" depends in part on the nature of the rights with which speech conflicts. If the right is one that is injured solely, or at least typically, by speech, it is natural to view the issue as one of determining the boundary between the two rights. ${ }^{384}$ On the other hand, rights that can be injured both by speech and by conduct are often defined most easily without reference to speech. In such cases, the issue is best formulated as whether speech should be privileged to override the right. ${ }^{385}$ Regardless of how the problem is framed, a similar analysis should apply. Under the rights-based theory, there are three related ways to approach conflicts between freedom of speech and other rights.

\section{Balancing of Rights}

The first method, balancing, seeks to determine which right has more value. This determination should be made at the margin - that is, instead of asking whether freedom of speech or (for example) the right to privacy has greater value in general, we should ask (1) to what extent the value of privacy would be impaired by the speech at issue, and (2) to what extent the value of free speech would be diminished by regulations to protect privacy. In this analysis, the existence of alternatives has great importance. A regulation of speech is not justified if there is a less restrictive alternative that would afford the same protection to other rights. By the same token, speakers are not justified in infringing other rights if the values underlying free speech would be promoted equally well without such infringement.

Of course, to assess the value of competing rights, we need a common standard by which to measure them. For the rights-based theory, that standard may be found in the same principles that justify these rights in the first place. Thus, rights have value as aspects of (1) external freedom, (2) internal freedom to develop and express one's personality, (3) freedom to participate in social and political life, and (4) intellectual and spiritual freedom. Ultimately, the value of a right reflects its importance as an aspect of human liberty and self-determination.

The value of rights is subject to a crucial constraint, however: an asserted right can derive no value from its negation of another right. For example, one who threatens another with violence might contend that his speech has value as a form of self-realization. From a rights-based perspective, however, the actor's self-

384 For example, the conflict between the right to privacy and the public's right to be informed on matters of public concern is best viewed in this way.

385 The way in which the problem is conceived is also partly a function of the source of the rights and the jurisdiction of the court. Where both rights derive from the same source (e.g., state law), the issue can often be viewed as one of adjustment. Many constitutional cases, on the other hand, involve a conflict between state-law rights and the First Amendment. In such cases, federal courts lack power to adjust the boundaries of rights that have been authoritatively defined by state law, and the court can rule in favor of free speech only by finding a constitutional privilege to override such rights. 
realization cannot count as a value insofar as it depends on causing another to fear violence. If the right to personal security has positive value, the negation of that right cannot also have such value. That is not to say that the actor's speech has no value at all: it may have value as an exercise of external freedom, or even as a form of self-realization, insofar as this derives from something other than the infliction of fear. Of course, these values are unlikely to justify serious invasions of personal security.

In short, when a particular act of speech comes into conflict with another right, balancing seeks to determine whether a restriction of speech is warranted by weighing (1) the value of the speech and (2) the extent of the restriction, against (3) the value of the other right and (4) the impact of unregulated speech on that right. The aim of this approach is to harmonize the competing rights by protecting both insofar as possible and, to the extent that they conflict, by protecting the right that (at the margin) constitutes the most important aspect of liberty.

It is essential to observe that, while this method involves balancing, it is fundamentally different from a generalized weighing of social interests. The latter approach regards speech, like other interests, as valuable insofar as it promotes social welfare. By contrast, the present approach assesses rights in terms of their value for human liberty. Under this approach, speech may be restricted only when necessary to protect another right that, under the circumstances, is more valuable as an aspect of freedom. This approach, unlike interest balancing, is therefore consistent with what John Rawls calls "the priority of liberty." 386

A final point concerns the level of generality at which the characterization and balancing of rights should occur. On one hand, it would be neither meaningful nor useful to ask whether, in the abstract, freedom of speech has more value than other rights such as personal security or privacy. As we have seen, all of these rights are fundamental and have a common basis in human liberty. Moreover, rights are not abstractions, but have force and meaning only insofar as they are realized in the world. Thus, the question is not the relative value of free speech or privacy in the abstract, but their value in actual instances.

On the other hand, an ad hoc balancing of rights in each case would be equally unsatisfactory. Rights are not mere claims to act in a specific way (or to be free from such action) in a particular situation. Instead, they reflect more general principles of liberty. Ad hoc balancing risks overlooking this deeper dimension of rights and deciding cases on the basis of merely subjective reactions and predilections.

386 RAWLS, THEORY OF JuSTICE, supra note 204, § 39, at 243. The priority of liberty holds that basic liberties may not be traded off against welfare. Id. $\S 39$. At the same time, Rawls observes that "when the liberties are left unrestricted they collide with one another," making it necessary "to balance one liberty against another" in order to promote the most extensive system of liberty as a whole. Id. §32, at 203. Ronald Dworkin also recognizes the need to balance rights when they conflict. See Dworkin, supra note 196 , at 193-94. 
In resolving conflicts of rights, then, we should not proceed on a level of either abstract generality or ad hoc particularity. Instead, the rights at issue should be delineated by applying the general concept of the right to the particular facts, or (what amounts to the same thing) by viewing specific facts in light of the general concept. The result is to identify certain sorts of speech and other rights. ${ }^{387}$ In other words, rights should be balanced at what has been called the "definitional" rather than the ad hoc level. ${ }^{388}$

\section{Internal Relationships Between Rights}

Although balancing is one useful method for resolving conflicts of rights, it is not the only one. In contrast to balancing, which involves an external comparison between rights, a second approach explores whether there is any internal relationship between them. ${ }^{389}$ In some instances, one right is partly defined in relation to another. As we have seen, for example, the right to reputation presupposes that others have a right to form accurate images of oneself. It follows that this right cannot be violated by true statements, however damaging they may be. ${ }^{390}$

In other cases, it may be argued that one right should prevail over another because it is more fundamental. For example, individuals cannot freely engage in speech unless they are safe against violence; a modicum of personal security is necessary for the enjoyment of other rights. In this sense, personal security is the most basic of freedoms. It follows that when free speech is used to seriously threaten the personal security of others, the latter right must prevail.

As we have seen, however, such relationships do not necessarily run in only one direction. Thus, while personal security is necessary for freedom of speech, the converse is also true. Free speech is essential to political freedom, the ultimate safeguard of all other rights. ${ }^{391}$ For this reason, political speech should be restricted only when it causes serious injury to other rights.

\section{The System of Constitutional Liberty}

This exploration of the relationship between rights suggests a further point: that they are integral to a larger whole. This leads to a third way of resolving conflicts,

387 As applied to New York Times v. Sullivan, 376 U.S. 254 (1964), for example, this approach would characterize the rights neither as "free speech" and "reputation," on one hand, nor as the right to publish this specific advertisement or to be free from these particular accusations, on the other hand. Instead, it would characterize these rights, as the Court did, at an intermediate level — as the right to criticize the official conduct of public officials, and the right to be free from false and defamatory statements about such conduct.

388 Nimmer, supra note 180 , at 942.

389 On this approach, see WALDRON, supra note 222, at 220-24.

390 See supra notes 323-24 and accompanying text.

391 See Palko v. Connecticut, 302 U.S. 319, 327 (1937) (observing that freedom of speech and thought "is the matrix, the indispensable condition, of nearly every other form of freedom"). 
which is to ask which right, under the circumstances, is most important to the system of constitutional liberty as a whole. To recast an earlier example, if individuals were permitted to assault or threaten others, the result would be to greatly weaken the overall system of liberty. On the other hand, the system would also be undermined if speech could be restricted because of distant or speculative fears of violence. ${ }^{392}$ Interpretations of the First Amendment that would lead to either result should therefore be rejected.

\section{Elaborating the Approach}

These three methods are closely related to one another. Each seeks to resolve conflicts of rights by identifying what is common to them and using this as a criterion to determine which should prevail. The first approach locates this common ground in the principles that underlie the competing rights; the second, in the internal relationship between them; and the third, in their relative importance to constitutional liberty as a whole. Rather than being mutually exclusive, these three approaches overlap with and reinforce each other. Constitutional arguments and decisions frequently rely on more than one to reach their conclusions.

Thus far, our discussion has focused on conflicts between free speech and some other right. It is crucial to recognize, however, that conflicts can also take place within free speech itself. For example, hecklers who attempt to drown out a speech at a public rally interfere both with the speaker's First Amendment rights and with those of the audience. While in this instance the interference results from the noncommunicative effect of speech, in others it may derive from communicative impact. That would be the case, for example, if one participant in an argument over politics threatened to strike another.

In such cases, First Amendment values are at stake on both sides. Conflicts of this sort can be analyzed through the same three-fold approach outlined above. First, loud noises and threats of violence clearly have less value, in terms of the four elements of liberty, than does the right to engage in political discourse. Second, personal security and the ability to be heard are necessary conditions for all freedom of speech. Speech that negates these conditions therefore undermines its own normative basis. Finally, it is clear that political expression holds a higher place in the system of constitutional liberty than the two forms of speech with which it here conflicts. In such cases, speech may properly be restricted for the sake of free speech itself.

Our discussion so far has also assumed, for purposes of clarity, that only two competing rights are involved. First Amendment problems often are more complex than this, however, involving multiple rights of individuals and the community. Suppose that an extremist speaker at a rally urges her followers to attack opponents who are staging a counter-demonstration nearby. To determine whether this speech should be protected, it is necessary to consider not only the speaker's right to free expression and the opponents' rights to personal security, but also the

392 See, e.g., Texas v. Johnson, 491 U.S. 397, 409 (1989). 
rights of the audience and the public to hear the speech, as well as the community's right to preserve the peace.

Resolving conflicts of rights is therefore a multifaceted process. Sometimes the answer is intuitively clear: no one would hold threats of imminent violence to be protected speech. Other problems call for more complex and difficult reasoning. In such cases, while a rights-based approach does not yield clear, uncontroversial results, it serves to focus our attention on the crucial issues - the relative value and importance of different aspects of liberty.

\section{B. An Illustration: Defamation and the First Amendment}

\section{Public Officials}

To illustrate how this theory would approach conflicts of rights, I want to briefly explore a central issue in modern free speech jurisprudence- how defamation should be treated under the First Amendment. The common law afforded strong protection to reputation, imposing a form of strict liability for false statements that injured an individual's reputation. ${ }^{393}$ In the landmark case of New York Times $v$. Sullivan, ${ }^{394}$ the Supreme Court was asked to determine what limits, if any, the First Amendment placed on the authority of states to impose liability for defamatory statements concerning the official conduct of government officials. The Court ruled that in such cases, officials could recover only on a clear-and-convincing showing that the defendant acted with "actual malice," that is, that the statement was knowingly or recklessly false. ${ }^{395}$

From a rights-based perspective, New York Times was clearly correct to resolve the conflict strongly in favor of speech. Although the right to reputation is an important one, in cases involving government officials the values served by free speech are at least as fundamental. As Justice Brennan emphasized in a related case, the ability of the people to debate public issues and assess the conduct of public officials is "the essence of self-government." 396 Such speech is therefore vital to political freedom, as well as to the protection of civil liberty against governmental oppression (which was a central theme of the allegedly defamatory advertisement in New York Times ${ }^{397}$ ). Moreover, restrictions on good-faith criticism may have a substantial impact on the willingness of individuals to criticize government officials, ${ }^{398}$ while allowing such speech may have much less marginal

393 See Prosser And Keeton, supra note 329, at 804.

394376 U.S. 254 (1964).

395 See id. at 279-80.

396 Garrison v. Louisiana, 379 U.S. 64, 74-75 (1964).

397 The advertisement is reproduced as an appendix to the Court's opinion. See 376 U.S. at 305 .

398 See id. at 279. 
impact on reputation, since officials can often effectively respond to attacks through counterspeech. ${ }^{399}$

Thus, a balancing of rights points toward strong protection of speech. This conclusion is greatly reinforced by the second approach, which explores the internal relationship between the two rights. An individual's reputation consists in what others say and think about him. The very concept of reputation presupposes that others will assess a person and his actions. ${ }^{400}$ It follows that reputation may be understood as a relational right - a right to interact with others in a particular way. Such rights are inherently limited by the corresponding rights of others - in this case, their right to freely discuss an individual and his actions. ${ }^{401}$

This free speech right is a mirror image of the right to reputation; it represents the same relationship between observer and observed, now viewed from the observer's perspective. It too is a relational right: it is a right to assess the character and conduct of an individual, insofar as one is affected by him, and to thereby shape his reputation. As a relational right, it is limited by the rights of the observed individual. As we have seen, reputation is, or should be, a reflection of a person's own actions as well as the way these are viewed by others. To misrepresent a person is to treat him as a mere object rather than as an autonomous subject.

In short, (1) the right to reputation and (2) the right to shape the reputation of others through speech may both be understood as relational rights, which represent two different aspects of the same relationship between persons as observers and observed. This relationship does not, however, exist merely in the abstract. Instead, it takes different forms in particular contexts. The form that the relationship takes will have a crucial bearing on the force of the respective rights.

In some contexts, observers and observed relate to one another as equals. ${ }^{402}$ In cases like New York Times, however, the relationship is a very different one. In a democratic society, government officials are regarded as representatives of the people, who as the ultimate sovereign have an inherent right to oversee their conduct. The relationship between the public and officials is therefore one of principal and agent, superior and subordinate. ${ }^{403}$ Because this relationship is an unequal one, so are the rights that inhere in it. It follows that the people's right to judge the character and actions of government officials is more fundamental than the latter's right to reputation.

In discussing the relationship between free speech and official reputation, we have been led to explore where each fits within the overall structure of constitutional liberty. This inquiry, the third way of approaching conflicts of rights, clearly supports the same result, for this form of free speech is the cornerstone of constitutional democracy.

399 See Gertz v. Robert Welch, Inc., 418 U.S. 323, 344 (1974).

400 See supra note 323 and accompanying text.

401 See supra note 361 and accompanying text (discussing concept of relational rights).

402 See infra Part III.B.2.

${ }^{403}$ For the historical roots of this view, see supra Part I.A. 
In short, New York Times was clearly right to afford a high level of constitutional protection to criticism of government officials. The standard of knowing or reckless falsity that the Court announced in that case seems to be a reasonable way of attaining this end. ${ }^{404}$

\section{Public and Private Figures}

A rights-based analysis also suggests that it was reasonable for the Court to extend the New York Times rule to cases involving public figures. ${ }^{405}$ Some prominent persons have an influence on political affairs comparable to that of public officials. In other instances, public figures play an important role in shaping the society and its culture. ${ }^{406}$ Although such individuals may not be elected, their status and influence derives from public recognition. A strong right to discuss the

404 In their concurring opinions, Justices Black, Douglas, and Goldberg contended that, rather than adopting an "actual malice" standard, the Court should have recognized "an absolute, unconditional privilege to criticize official conduct despite the harm which may flow from excesses and abuses." 376 U.S. at 296 (Goldberg, J., joined by Douglas, J., concurring in result); see also id. at 297 (Black, J., joined by Douglas, J., concurring) ("An unconditional right to say what one wants about public affairs is what I consider to be the minimum guarantee of the First Amendment."). From the standpoint of substantive right, this position is unconvincing. As Justice Brennan argued in Garrison v. Louisiana, 379 U.S. 64 (1964), while good-faith criticism of government officials must be protected by the First Amendment, "calculated falsehood" undermines rather than promotes the community's ability to make informed judgments. Id. at 73-75. A rule of absolute protection would sacrifice legitimate rights of reputation without advancing the paramount rights of the public.

As we have seen, however, the law must take account of institutional as well as substantive justice. See supra notes 224-26 and accompanying text. The concurring Justices emphasize the difficulty of determining a speaker's state of mind and the danger that juries will use libel law to suppress unpopular views. See 376 U.S. at 293-95 (Black, J. concurring); id. at 300 (Goldberg. J., concurring in result). These concerns clearly justify New York Times's adoption of a demanding standard of liability, a requirement of clear and convincing evidence, and independent judicial review of libel awards. The question is whether these measures are sufficient, or whether an absolute First Amendment privilege is necessary to ensure adequate latitude to criticize government officials.

Issues of this sort cannot be resolved on a theoretical level, but only through the exercise of informed practical judgment. In making such a judgment, it is important to remember that free speech and other rights are not sharply antithetical to one another, but essential elements of a broader system of constitutional liberty. The aim of constitutional adjudication should be to reconcile such rights as far as possible. Thus, a right that is justified in principle should be limited for institutional reasons only to the extent necessary to promote right as a whole. For further discussion of the role of institutional right, see infra notes 523-27 and accompanying text.

405 Curtis Publ'g Co. v. Butts and Associated Press v. Walker, 388 U.S. 130 (1967).

406 See supra notes 362-63 and accompanying text. 
character and conduct of public figures is therefore supported by considerations similar to those in New York Times.

In Rosenbloom v. Metromedia, Inc., ${ }^{407}$ a plurality of the Court contended that the First Amendment should afford the same high level of protection to all communication on matters of public concern, regardless of whether they involve government officials or public figures. ${ }^{408}$ For this reason, the plurality held that private individuals who were falsely accused in the media could recover only if they could meet the New York Times standard of knowing or reckless falsity. ${ }^{409}$ Three years later, however, in Gertz v. Robert Welch, Inc., ${ }^{410}$ the Court overruled Rosenbloom, concluding that it unduly restricted the authority of states to protect private reputation. ${ }^{411}$ A rights-based analysis suggests that this conclusion was sound.

As the social aspect of personality, reputation is central to individual dignity and self-realization. ${ }^{412}$ Moreover, in contrast to those who seek public office or other forms of prominence, individuals who remain in the private sphere cannot be regarded as giving up this right, nor do they generally have effective means of responding to defamatory reports. ${ }^{413}$

On the other hand, it is true, as Justice Brennan argued in Rosenbloom, that the conduct of private individuals is often a matter of public concern. ${ }^{414}$ In order to assess the strength of this interest, we must begin by recognizing that "public" has more than one meaning. In one sense, it refers to the people collectively, that is, to the polity or community as a whole. In another sense, it refers to the people regarded as an aggregate of private individuals. ${ }^{415}$

Individual conduct can be a matter of public concern in both senses. First, as private individuals, people often show a strong desire and interest in knowing about the lives of others. As businesses, the media have an interest in meeting the demand for such information. This activity is a legitimate one, so long as it respects privacy, reputation, and other rights.

It should be clear, however, that the relationship between free speech and reputation is quite different in this context than it was in New York Times. In that setting, the individuals who were subject to observation were the agents and subordinates of those who desired to observe their conduct - the people in their capacity as citizens. For this reason, the right to free speech was more fundamental than that of reputation. By contrast, no such inequality exists between private figures and other private parties who wish to report upon or learn about their lives. To be

407403 U.S. 29 (1971).

408 See id. at 43-44 (plurality opinion).

409 See id. at 52.

410418 U.S. 323 (1974).

411 See id. at 345-46.

412 See supra Part II.C.2.c.

413 See 418 U.S. at 344-45.

414 See 403 U.S. at 43-44.

415 See Aristotle, Politics bk. II, ch. 3, at 1261b20-32 (Carnes Lord trans., 1984). 
sure, individuals do have a right to make judgments about the character and conduct of others. In the present context, however, the observers and observed are on a level of equality. The right of the former to judge is no stronger than the right of the latter to be represented in a way that accurately reflects their actions and character.

Insofar as individual conduct affects the community, it may also be of public concern in the collective sense. Thus, the public has a legitimate interest in knowing about crimes and other conduct that violates the norms of the community. ${ }^{416}$ Again, however, individuals are not subordinate to the community in the same sense that public officials and figures are. While the latter owe their status and influence to the society, the society is obligated to recognize the status and rights of individuals. Although the community has a right to make judgments about the conduct of its members, individuals equally have a right that such judgments be as accurate as possible. In the same way that there is a right to due process in legal proceedings, there should be an analogous right when a person is tried in the court of public opinion.

This analysis of the relationship between free speech and private reputation suggests that neither of these rights is more fundamental than the other. Exploring their role in the system of constitutional liberty leads to the same conclusion. The New York Times decision was based on the Madisonian view that the "right of freely examining public characters and measures ... [is] the only effectual guardian of every other right." 417 The right of private reputation, on the other hand, is among the fundamental rights that society is intended to protect. As Justice Stewart observed, this right "reflects no more than our basic concept of the essential dignity and worth of every human being - a concept at the root of any decent system of ordered liberty." 418

It follows that free speech confers no general right to violate private reputation. Because these rights are of the same order of value, it was reasonable for Gertz to hold that defendants may be held responsible for injury to reputation when they are at fault, that is, when they fail to use reasonable care to determine whether a defamatory statement is actually true..$^{419}$

\section{Conclusion}

Parts II and III have outlined a rights-based theory of the First Amendment. According to this view, the same aspects of human liberty that justify freedom of speech and thought also give rise to other fundamental rights, including personal security, privacy, reputation, and citizenship. Free speech may not infringe these rights without adequate justification. Conflicts between rights should be resolved

\footnotetext{
416 On the formation of social norms, see Richard H. McAdams, The Origin, Development, and Regulation of Norms, 96 MicH. L. REV. 338 (1997).

417 Madison, Report, supra note 102, at 144.

418 Rosenblatt v. Baer, 383 U.S. 75, 92 (1966) (Stewart, J., concurring).

419 See 418 U.S. at 347.
} 
in light of their relative value, the relationship between them, and their respective roles in the system of constitutional liberty.

1. The Rights-Based Theory Contrasted with Contemporary First Amendment Jurisprudence: Florida Star v. B.J.F.

The contrast between this view and contemporary jurisprudence is strikingly illustrated by the 1989 case of Florida Star v. B.J.F.420 After being raped and robbed at knifepoint by an unknown assailant, B.J.F. reported the incident to the county sheriff's department. A crime report posted in the department's pressroom inadvertently failed to delete the victim's name. A reporter for the Florida Star took down all the information in the report, although she knew from a sign in the pressroom that the names of rape victims were not matters of public record and could not be published under Florida law. The Star then published an account of the rape, identifying B.J.F. by name. In addition to comments from coworkers and acquaintances, B.J.F. and her family received several telephone calls from a man who threatened to rape her again. These events forced her to move, to change her telephone number, and to seek police protection as well as psychological counseling. B.J.F. brought a civil action against the Star for violating a Florida statute which made it unlawful to publish the name of a sexual-assault victim in any instrument of mass communication. ${ }^{421}$ Finding that the newspaper had "acted with reckless indifference to the rights of others," the jury awarded her $\$ 75,000$ in compensatory damages and $\$ 25,000$ in punitive damages. ${ }^{422}$

On appeal, the Supreme Court overturned the award under the First Amendment. Reflecting the assumptions of modern free speech jurisprudence, Justice Marshall framed the issue as a clash between the right of the press to publish truthful, lawfully obtained information, and the "state interest[s]" in protecting the privacy and safety of rape victims and in encouraging them to report assaults. ${ }^{423}$ Although the Court acknowledged that these were "highly significant interests," it held that, under the circumstances, the statute was not necessary to protect them, for the government could have prevented the harm simply by not disclosing the information. ${ }^{424}$ Moreover, the law was underinclusive because it applied only to dissemination by the media, not by individuals, a fact that raised serious doubts about whether it was effective in promoting these state interests. ${ }^{425}$ For these reasons, the statute could not survive strict scrutiny.

420491 U.S. 524 (1989). The facts in this paragraph are taken from Justice Marshall's majority opinion, see id. at 527-29, supplemented by Justice White's dissent, see id. at 546.

421 See Florida Stat. § 794.03 (1987).

422491 U.S. at 529.

${ }^{423} \mathrm{Id}$. at 533-34.

424 Id. at 537.

425 See id. at 540-41; see also id. at 541-42 (Scalia, J., concurring in part and in the judgment). 
The Florida Star case would look very different from a rights-based perspective. On this view, it is clear that the statute's aim was not to promote the interests of the state but to protect the rights of the victim. The government's inadvertent failure to comply with the law should not have the effect of waiving B.J.F.'s rights, or relieving the newspaper of its own responsibility to respect them. As to the statute's scope, it is reasonable to believe that publication causes more serious injury than mere private discussion and that a ban on the latter would be unnecessarily intrusive. Moreover, even if the Florida law could be faulted for underprotecting privacy, it is difficult to see why that should lead us to deny protection to that right in a case that falls within the statute's scope.

Rather than applying a standard heavily weighted toward one side of the balance, the rights-based theory would compare the competing rights in terms of their value for human liberty. In a case like Florida Star, publishing the victim's name causes serious injury to fundamental rights of privacy and personal security. As Justice Marshall implicitly conceded, although there is an important public interest in learning about "the commission, and investigation, of a violent crime which has been reported to the authorities," that interest does not necessarily extend to the "specific identity" of the victim. ${ }^{426}$ On the rights-based view, then, the First Amendment should not prevent states from protecting the identities of rape victims in cases of this sort. ${ }^{427}$

\section{Two Objections}

\section{a. May Speech Be Restricted to Protect Nonconstitutional Rights?}

In concluding this overview, I would like to consider two objections to the rights-based theory. First, it might be argued that, even if free speech can properly be restricted for the sake of other rights, this may be done only to protect rights that themselves enjoy constitutional status - not those such as reputation, which derive merely from state law. Although this objection is plausible, a little reflection shows that it would lead to unacceptable results. For example, few would deny that the law may restrict speech that threatens imminent violence. Yet the right to be free from private violence, like the right to reputation, is protected not by the Constitution but by state law.

In responding to this objection, we should begin by noting that it reflects the assumptions of legal positivism. According to that view, rights have no independent existence, but derive their force from positive law. ${ }^{428}$ It may seem to follow that rights that are protected by the Federal Constitution necessarily have

\footnotetext{
${ }^{426}$ Id. at 536-37.

427 A more difficult problem would be presented in contexts where a substantial public interest would be served by publication, such as reporting public proceedings in a criminal trial. See, e.g., Cox Broad. Corp. v. Cohn, 420 U.S. 469 (1975) (rape victim's name obtained from public judicial records).

428 See supra notes 129-34 and accompanying text (discussing Holmesian positivism).
} 
greater authority than those that are safeguarded merely by statutory or common law. In cases of conflict, therefore, the latter rights must yield to the former.

As we have seen, however, the Constitution, Bill of Rights, and Fourteenth Amendment were grounded in a very different understanding of the nature of rights. On that view, individuals derive their rights not from positive law but from nature. Society and government are formed to protect these rights against invasion by other individuals. Once government is established, it also becomes necessary to safeguard these rights against the power of government itself. The object of a bill of rights is not to create fundamental rights, but merely to secure those rights against the government.

According to this view, rights safeguarded by ordinary civil and criminal law may be no less fundamental than those protected by the Constitution itself. The importance of a right ultimately depends on its relation to human liberty, not on the particular form in which the right is protected by positive law. As we have seen, the rights explored in Part II derive from the same principles as free speech itself. For this reason, they have the same fundamental value, even if they are not themselves constitutional rights.

That is not to say, of course, that the Constitution should not prevail in cases where it conflicts with ordinary law. It is merely to say that, in interpreting the scope of the First Amendment, we should not readily assume that it abrogates fundamental rights protected by other laws. To put it differently, the Constitution not only secures rights, but also grants certain powers to the federal government, while reserving others to the states. These powers include the authority to make and enforce laws for the protection of rights. Strictly speaking, then, the rights-based theory does not hold that constitutional rights can be limited by nonconstitutional ones. Instead, it merely holds that constitutional rights must be interpreted in the context of the Constitution as a whole, including those provisions that grant or recognize the authority to protect other fundamental rights. The rights-based theory is therefore fully consistent with the status of the Constitution as supreme law. ${ }^{429}$

429 Indeed, it can be argued that the Constitution not only authorizes but requires the government to protect fundamental rights. According to the natural rights tradition, government has a duty to protect its citizens against the invasion of their rights by others. This notion was a central feature of American constitutional thought between the Revolution and the Civil War. A strong case can be made that the framers of the Fourteenth Amendment, concerned about the denial of protection to Southern blacks following the war, intended to incorporate such a right to protection into the first section of the Amendment. See Heyman, First Duty, supra note 361. If the Fourteenth Amendment were interpreted in this way-contrary to the Supreme Court's view in DeShaney v. Winnebago County Department of Social Services, 489 U.S. 189 (1989)-then one could argue that the government has a constitutional obligation to protect fundamental rights against violation by others, whether that violation takes the form of speech or conduct. We need not go that far for the purposes of this Article, however, for even if the Constitution does not require government to regulate speech where necessary to 
Moreover, in an important sense it would be incorrect to say that the Constitution does not recognize the rights discussed in Part II. Although it generally does not protect those rights against private parties, ${ }^{430}$ the Constitution does safeguard many of them against the government itself. The rights to life, liberty, and property are protected by the Fifth and Fourteenth Amendments. Along with the Fourth Amendment, ${ }^{431}$ these provisions have also been held to protect certain rights of privacy. ${ }^{432}$ The right to individual self-determination is an important theme in the Court's liberty and privacy decisions. ${ }^{433}$ The right to citizenship is secured by the Fourteenth Amendment, ${ }^{434}$ and rights of political participation have been held protected by that Amendment as well as other constitutional provisions. $^{435}$ Finally, the Ninth Amendment reminds us that the people retain other rights which should not be "den[ied] or disparage[d]" on the ground that they are not specifically mentioned in the Constitution. ${ }^{436}$ All of these rights, which are shielded by constitutional law against the power of government, should be regarded as equally fundamental when protected against private violation by civil and criminal law.

Thus, the rights discussed in Part II should not be discounted on the ground that they lack constitutional status. This point was expressed most eloquently by Justice Stewart in his concurring opinion in Rosenblatt v. Baer. 437 After observing that the right to reputation is essential to individual dignity, Justice Stewart added, "The protection of private personality, like the protection of life itself, is left primarily to the individual States under the Ninth and Tenth Amendments.

protect the fundamental rights of others, it should be interpreted to permit government to do so.

430 An exception is the Thirteenth Amendment, which outlaws slavery whether or not supported by state action.

431 See, e.g., Katz v. United States, 389 U.S. 347 (1967); see also Olmstead v. United States, 277 U.S. 438, 471 (1928) (Brandeis, J. dissenting).

432 See, e.g., Whalen v. Roe, 429 U.S. 589, 599-600 (1977) (observing that the Court's privacy decisions under the Fifth and Fourteenth Amendments and other constitutional provisions have recognized two distinct interests in privacy, "the individual interest in avoiding disclosure of personal matters" and "the interest in independence in making certain kinds of important decisions"); Roe v. Wade, 410 U.S. 113, 153 (1973) (holding that "the Fourteenth Amendment's concept of personal liberty" includes a "right of privacy" that "is broad enough to encompass a woman's decision whether or not to terminate her pregnancy").

433 See, e.g., Planned Parenthood v. Casey, 505 U.S. 833, 851 (1992) (plurality opinion).

434 See U.S. CONST. amend. XIV, § 1 ("All persons born or naturalized in the United States, and subject to the jurisdiction thereof, are citizens of the United States and of the State wherein they reside.").

435 On the Supreme Court's decisions on the right to political participation, see generally TRIBE, supra note 120 , ch. 13 .

436 U.S. CONST. amend. IX.

437383 U.S. 75 (1966). 
But this does not mean that the right is entitled to any less recognition ... as a basic of our constitutional system." 438

\section{b. Does a Rights-Based Approach Undermine Freedom of Expression?}

It may be objected further that, while the rights-based approach affords strong protection to other fundamental rights, it does so at too high a cost to free speech. Far from undermining freedom of expression, however, a rights-based approach actually strengthens the normative basis of that right in two ways. First, the more that free speech is regarded as authorizing the violation of other important rights, the more difficult it becomes to discern a difference between speech as a right and as a wrongful invasion of the rights of others. The result is to undermine the rightfulness of free speech. Thus, a defense of free speech that tends towards absolutism ironically may weaken the normative basis of that right, as well as diminish public support for it. By contrast, free speech may enjoy the strongest status as a right when it must be exercised with due regard for the rights of others.

A second point relates to the teleology of free speech. Americans have traditionally thought of freedom of speech as promoting the good of society and its members. ${ }^{439}$ As we have seen, however, rights such as personal security, privacy, and reputation reflect the same fundamental values as free speech itself, and are also essential to the individual and social good. It is impossible, however, for a society to attain all goods to an unlimited degree. Where different goods compete, achieving one will result in some sacrifice of another. When speech that has relatively little value for human liberty infringes rights that have substantial value, protecting the speech has the result of diminishing rather than promoting the good. Thus, free speech furthers the individual and social good most effectively when it is required to respect the rights of others.

\section{APPLICATIONS}

I now wish to explore how the rights-based model would apply to two important issues in contemporary First Amendment jurisprudence. I shall begin with the problem of "fighting words," and then turn to that of hate speech.

\section{A. Insulting or Fighting Words}

\section{The Chaplinsky Case}

In Chaplinsky v. New Hampshire, ${ }^{440}$ the Supreme Court unanimously upheld a statute making it an offense to "address any offensive, derisive, or annoying word to any other person who is lawfully in any street or other public place, [or] call

438 Id. at 92 (Stewart, J., concurring).

439 See, e.g., Abrams v. United States, 250 U.S. 616, 630 (1919) (Holmes, J., dissenting) (arguing that "the ultimate good desired" by members of society can best be achieved through freedom of speech).

440315 U.S. 568 (1942). 
him by any offensive or derisive name." 441 Chaplinsky had called a city official "a God damned racketeer" and "a damned Fascist." 442 Affirming the conviction, Justice Murphy held that the First Amendment did not protect "insulting or "fighting' words," which he defined as "those which by their very utterance inflict injury or tend to incite an immediate breach of the peace." ${ }^{443}$ Such words, he wrote, "are no essential part of any exposition of ideas, and are of such slight social value as a step to truth that any benefit that may be derived from them is clearly outweighed by the social interest in order and morality." 444

Chaplinsky is a paradigm case of the modern tendency to conceptualize First Amendment problems as conflicts between free speech and social interests-in this case the "interest in order and morality." 445 This understanding of the problem has led to a vigorous debate. On one hand, Chaplinsky has come under fire from many civil libertarians, who fear that it imposes an unjustified limitation on free speech. ${ }^{446}$ On the other hand, the doctrine has found defenders on both the right and the left, who argue that it is necessary in order to preserve civility ${ }^{447}$ or to protect disadvantaged groups from psychological injury and social subordination. ${ }^{448}$ When posed in this way, the problem appears to present a "tragic conflict" in which we can protect freedom of expression only by sacrificing other essential values such as civility or equality, and can protect the latter only by doing violence to the ideal of free speech. ${ }^{449}$

\section{Tendency to Provoke a Breach of the Peace}

How would this problem look if it were recast in terms of opposing rights? Traditionally, the law regarded insults as wrongful because of their tendency to incite a breach of the peace. At first blush, this rationale appears inconsistent with a

441 Id. at 569.

442 Id.

443 Id. at $571-72$.

444 Id. at 572.

445 See supra Part I.D. In formulating the problem in this way, the Court explicitly followed Chafee. See 315 U.S. at 572 (citing Zechariah Chafee, Jr., Free Speech in the United STATES 149-50 (1941)).

446 See, e.g., Haiman, supra note 331, at 252-60; Stephen W. Gard, Fighting Words as Free Speech, 58 WASH. U.L.Q. 531 (1980); Nadine Strossen, Regulating Racist Speech on Campus: A Modest Proposal?, 1990 Duke L.J. 484, 508-14.

447 See Hadley Arkes, Civility and the Restriction of Speech: Rediscovering the Defamation of Groups, 1974 Sup. CT. REV. 281, 305-17.

448 See, e.g., Richard Delgado, Words That Wound: A Tort Action for Racial Insults, Epithets, and Name-Calling, 17 Harv. C.R.-C.L. L. Rev. 133, 173-74 (1982); Charles Lawrence, If He Hollers Let Him Go: Regulating Racist Speech on Campus, 1990 DUKE L.J. 431, 449-57 (1990).

449 For the view that free speech problems often involve "tragic choices" of this kind, see Susan H. Williams, Feminist Jurisprudence and Free Speech Theory, 68 Tul. L. REV. 1563, 1579 (1994). 
rights-based theory, for it seems to allow rights to be restricted merely because others may respond lawlessly. Rather than punishing the speaker, would it not be preferable for the law to simply hold people responsible for their own violent acts? ${ }^{450}$

This objection has great force when applied to a broad notion of fighting words that would make the lawfulness of speech turn simply on the reaction of others. One who is properly exercising her First Amendment rights should not be restricted simply because others may act wrongfully. ${ }^{451}$ The objection is itself too sweeping, however, because it fails to distinguish between rightful and wrongful acts of speech. Under a rights-based model, speech may properly be restricted when it is likely to provoke violence because of its wrongful character.

Speech is wrongful when it constitutes a form of aggression against others. As Alexander Bickel puts it, "There is such a thing as verbal violence, a kind of cursing, assaultive speech that amounts to almost physical aggression, bullying that is no less punishing because it is simulated." ${ }^{252}$ The 1982 case of Gomez v. Hug ${ }^{453}$ provides a dramatic example. After ordering a county employee to walk over to him, the defendant, a county commissioner, allegedly shouted, "You are a fucking spic. ... A fucking Mexican greaser like you, that is all you are. You are nothing but a fucking Mexican greaser, nothing but a pile of shit."454 He then added, "Are you going to do something, you coward, you greaser, you fucking spic? What are you going to do? Don't stand there like a damn fool because that is all you are is a pile of shit." 455

It is hardly surprising that speech of this sort, which seeks to abuse or dominate others on a visceral level, often leads to violence. Human beings have a deeply

450 See Haiman, supra note 331, at 258.

451 See Feiner v. New York, 340 U.S. 315, 326-27 (1951) (Black, J., dissenting).

452 Alexander M. Bickel, The Morality of Consent 72 (1975). Bickel extends this notion beyond the fighting words context, to the use of profane language in public discourse. For criticism of this aspect of Bickel's argument, see Daniel A. Farber, Civilizing Public Discourse: An Article on Professor Bickel, Justice Harlan, and the Enduring Significance of Cohen v. California, 1980 DuKE L.J. 283.

453645 P.2d 916 (Kan. Ct. App. 1982). Many of the examples in this Part contain profoundly offensive language, for which I apologize. Unfortunately, discussions of the First Amendment frequently take place on an abstract level, without considering the exact nature of the expression at issue-something that I believe we must do to reach thoughtful judgments about whether it should be constitutionally protected.

454 Id. at 918

455 Id. For similar facts, see Bailey v. Binyon, 583 F. Supp. 923 (N.D. Ill. 1984). In that case, the plaintiff's employer allegedly called him a "nigger" several times and told him that "all you niggers are alike." Id. at 925. When the plaintiff said that he did not appreciate the racial slurs and that he "wanted to be treated "like a human being,", the employer responded, "You're not a human being, you're a nigger." Id. As the employee began to leave, the employer called him a sissy and said that if he were a man he would stay. See id. The court denied a motion to dismiss the employee's claims for civil rights and Title VII violations. See id. at 934. 
ingrained tendency to respond to others in the same way that they themselves are treated. Thus, individuals who are confronted with aggression often respond in kind. To be sure, fighting words constitute merely verbal assaults. But speech of this sort does not recognize a clear distinction between verbal and physical attack. Moreover, because it aims at superiority over others, verbal aggression tends to initiate an escalating cycle of hostilities that may swiftly culminate in violence.

In addition to freedom from aggression, fighting words often violate other individual rights, including the right to personal dignity. ${ }^{456}$ But human beings have a tendency to react with force when their rights are attacked. This is a second reason why fighting words are wrongful, and why they tend to provoke a violent response.

At the same time, it is important to stress that the fighting words doctrine does not imply that individuals may rightfully respond to insults with violence. The law expects citizens to refrain from violence, except where necessary to defend themselves or their property against imminent attack. ${ }^{457}$ People who respond to fighting words with violence may themselves be found guilty of breaching the peace. The Chaplinsky doctrine therefore does not imply that individuals will not be held responsible for their own acts. It merely means that a speaker who deliberately uses words likely to provoke violence should also bear responsibility for the resulting confrontation. ${ }^{458}$

This defense of the fighting words doctrine may be summarized as follows. It is precisely because fighting words "inflict injury" that they "tend to incite an immediate breach of the peace." Fighting words cause injury through visceral aggression and by attacking the target's rights. Individuals who are injured in this way have a strong tendency to respond on the same level, even though that response may itself be wrongful. Properly understood, then, the fighting words doctrine does not allow an individual's legitimate exercise of free speech to be restricted merely because of the wrongful conduct of others. Instead, it is because of their

456 See infra note 463 and accompanying text.

457 See, e.g., LAFAVE \& SCOTT, supra note 249, §§ 5.7-5.9 (2d ed. 1986) (discussing self-defense, defense of others, and defense of property); RESTATEMENT, supra note 241, $\S \S 63-86$ (same).

458 In many cases, fighting words are used with the intention of challenging another to fight. In Gomez, for example, the defendant's invective included calling the plaintiff a "coward" and demanding to know what he was "going to do" about it. 645 P.2d at 918. The defendant in Binyon v. Bailey used similar language. See supra note 455 . In such cases, it seems even more clear that the speaker should be regarded as partly responsible for the resulting threat to the peace. The Model Penal Code adopts this view when it recognizes an offense of "harassment by fighting words," which it defines as occurring when one, "with purpose to harass another,... insults, taunts or challenges another in a manner likely to provoke violent or disorderly response." MODEL PENAL CODE, supra note $259, \S 250.4$ (2) (emphasis added). In a comment, the Code traces the concept of fighting words in part to the common law's recognition of an offense of challenging another to fight. Id. at 364. For the common-law position, see 4 BLACKSTONE, supra note 50 , at $* 150$. 
wrongful character that fighting words have a tendency to provoke violence. In this way fighting words violate individual rights as well as the community's right to the peace.

\section{Words That Inflict Injury by Their Very Utterance}

In recent decades, the Supreme Court has emphasized one branch of the Chaplinsky definition - the speech's tendency to provoke a violent response - to the apparent exclusion of the other - its capacity to inflict injury "by its very utterance."459 As several writers have observed, however, under this approach abusive language is entitled to greater constitutional protection the less that the target is able to defend herself. ${ }^{460}$ Such an approach would make perfect sense if the sole purpose of Chaplinsky were to prevent the addressee from responding with violence. We may well believe, however, that a relatively defenseless person should be entitled to at least as much protection from abusive speech as one who is able to defend herself. As I have suggested, abusive speech tends to provoke violence precisely because of the injury that it inflicts. This injury may be a serious one even when violence is not likely to ensue.

Insults can inflict injury in several ways. First, as we have seen, they may constitute a form of aggression against others. One's right to be free from such aggression should not depend on whether one is likely to respond with force. Instead, it should be understood as a facet of the right to personal security.

Abusive speech may also constitute an attack on personality. In some cases, the injury may be severe enough to allow recovery for intentional infliction of emotional distress. In Gomez, for example, the court allowed the plaintiff to proceed with such an action. ${ }^{461}$ Suppose, however, that Gomez did not suffer severe distress from the incident, either because of great fortitude or because he had become inured to repeated abuse. In that case, he would not be able to satisfy the requirements for intentional infliction. ${ }^{462}$ Yet it seems clear that he would have suffered a serious injury to personality.

459 See, e.g., Gooding v. Wilson, 405 U.S. 518 (1972) (holding state statute unconstitutionally vague and overbroad because not limited to words that by their very utterance tend to incite immediate breach of peace). But cf. R.A.V. v. City of St. Paul, 505 U.S. 377 (1992) (assuming for purposes of argument that Chaplinsky definition as a whole remains good law).

460 See, e.g., Kent Greenawalt, Insults and Epithets: Are They Protected Speech?, 42 Rutgers L. ReV. 287 (1990); Lawrence, supra note 448, at 453-54. As Greenawalt points out, for example, speech that would constitute unprotected fighting words when directed toward a strong young man could be used with impunity toward an elderly disabled person. See Greenawalt, supra, at 297-98.

461 Gomez v. Hug, 645 P.2d 916, 922 (Kan. Ct. App. 1982).

462 See Restatement, supra note $241, \S 46$ \& cmt. j (limiting recovery to cases in which "the distress inflicted is so severe that no reasonable man could be expected to endure it"). 
How can we understand the nature of this injury? In Part II.C, I argued that the right to personality includes not only freedom from substantive injury-infliction of emotional distress - but also a formal right to the inviolability of personality. This right was violated by invasion of privacy, the unreasonable intrusion into or exposure of an individual's private life. ${ }^{463}$ Like invasion of privacy, profoundly abusive speech should be understood as an attack on the right to an inviolate personality. Regardless of whether it causes severe distress in a particular case, the sort of speech involved in Gomez impacts the victim's consciousness in much the same way that offensive contact impacts the body. In effect, abusive speech constitutes an offensive battery to personality.

This is not to suggest that individuals have a right to be free from all offense. Like other rights, the right to personal dignity is rooted in a conception of people as rational and autonomous beings. As we have seen, individuals cannot reasonably complain of offense caused by the expression of ideas contrary to their own. ${ }^{464}$ Moreover, while everyday interaction generally does not require nonconsensual bodily contact, it does involve contact with the minds and feelings of others. It follows that, in contrast to the law of offensive battery, slight contact with the consciousness of others cannot be regarded as a wrong, even if they reasonably find it offensive. Instead, such contact is wrongful only if it is intended to and does cause a high level of offense. In defining the subcategory of words "which by their very utterance inflict injury," 465 we might look to the law of privacy and require that the speech intentionally attack the dignity of another in a way that is "highly offensive to a reasonable person." 466

\section{Conclusion}

To summarize, abusive speech should be considered wrongful if it intentionally (1) constitutes visceral aggression against or violates the fundamental rights of the target, and is thereby likely to result in a breach of the peace, or (2) violates the target's right to personality by inflicting severe emotional distress or assailing his dignity in a way that a reasonable person would find highly offensive. Before we can determine whether Chaplinsky was correct in holding such speech unprotected by the First Amendment, however, we must first consider whether the value of such speech is sufficient to justify the injuries that it causes to other rights.

Of course, carefully drawn laws against "insulting or "fighting words" would have little impact on free speech regarded simply as a form of physical liberty. It

463 See supra Part II.C.2.b.

464 See supra notes 291-92 and accompanying text.

465 Chaplinsky v. New Hampshire, 315 U.S. 568, 572 (1942).

466 RESTATEMENT, supra note 241, §§ 652B (defining tort of intrusion upon seclusion), $652 \mathrm{D}$ (a) (defining tort of giving publicity to private life). If this standard is considered too low, we might look instead to the Restatement's definition of intentional infliction of emotional distress, and require that the attack amount to "extreme and outrageous conduct." $I d$. $\S 46$. 
has been argued, however, that insults may have value as self-expression. ${ }^{467}$ But any value that such speech has for the speaker's own self-realization clearly derives from its negation of the personality and rights of the target. For this reason, this value cannot serve to justify the speech under a rights-based theory. ${ }^{468}$

If we view speech as involving not merely self-expression but communication, ${ }^{469}$ it is even more clear that such speech cannot be justified under the First Amendment. Communication presupposes that the participants regard each other as persons capable of engaging in discussion. This premise is undermined by speech like that in Gomez, that treats the other as a mere object of hostility and contempt. Thus the freedom to engage in reasoned discussion is, if anything, enhanced rather than diminished by restrictions on abusive speech. ${ }^{470}$

In some instances, insulting or fighting words may have political content. That might be the case, for example, when the Ku Klux Klan burns a cross in front of someone's home. I shall discuss this problem below in connection with hate speech. The facts of Chaplinsky itself present a more straightforward issue. Although the defendant's language to the city official may have contained an element of personal abuse, it can best be understood as a forceful protest against his official conduct, and as a criticism of the city government and its officials. Such speech should be protected because of its value as political speech, for much the same reasons as in New York Times v. Sullivan.

\section{B. Hate Speech}

Finally, let us turn to the problem of hate speech-whether the First Amendment should protect expression that abuses or degrades others on the basis of such traits as race, ethnicity, gender, and religion. ${ }^{471}$ In approaching this issue, the rights-based theory begins with the concept of recognition.

For the natural rights tradition, rights are ultimately rooted in personhood. It follows that an individual cannot enjoy rights in relation to others unless they recognize him as a free person. Recognition is the most fundamental right that individuals have in relation to others, a right that lies at the basis of all of their other

467 See, e.g., REDISH, supra note 169, at 55-56.

468 See supra Part III.A.1.

469 On the distinction, see supra note 365 and accompanying text.

470 See Lawrence, supra note 448, at 452-56. This view is consistent with Meiklejohn's notion that rules of order make free discussion possible. See supra note 360 and accompanying text; see also RAWLS, THEORY OF JUSTICE, supra note 204, § 32, at 203 (following Meiklejohn's view).

471 The literature on hate speech is vast. For some collections of major writings, see Henry louis Gates et al., Speaking of Race, Speaking of Sex: Hate Speech, Civil Rights, ANd Civil Liberties (1994); Mari J. Matsuda et AL., Words that Wound: Critical Race Theory, Assaultive Speech, and the First Amendment (1993); Hate Speech And the Constitution (Steven J. Heyman ed., 1996). On the history of the issue, see Samuel Walker, Hate Speech: The History of an American Controversy (1994). 
rights. For this reason, individuals have an inherent obligation to recognize and treat others as free and equal persons. ${ }^{472}$

This view provides a powerful perspective from which to approach the hate speech issue. Hate speech can best be understood as expression that intentionally denies recognition to others, and expresses hostility toward them, on the basis of such traits as race, ethnicity, gender, and religion. In addition to conflicting with fundamental principles of right, such speech in many cases violates the concrete rights of individuals and the community. In such cases, the expression is properly subject to regulation under the rights-based approach, unless its value is sufficient to outweigh the injuries that it causes. In developing this view, it will be useful to begin with private hate speech, or that directed toward particular individuals, and then turn to the problem of public or political hate speech.

\section{Private Hate Speech}

\section{a. Should Private Hate Speech Be Protected by the First Amendment?}

In many cases, private hate speech violates the target's right to personal security, the community's right to the public peace, or both. Such speech amounts to an assault when (together with other acts or circumstances) it intentionally causes apprehension of imminent attack. ${ }^{473}$ Threats of future harm may also constitute a

472 For a discussion of recognition in Hobbes, Locke, and other early modern natural rights theorists, see Steven J. Heyman, Hate Speech and the Theory of Free Expression, in HATE SPEECH AND THE CONSTITUTION, supra note 471, at xli-xlii, xlvii-xlix [hereinafter Heyman, Hate Speech]. The concept of recognition and its relationship with right are more fully developed by later writers, especially Fichte and Hegel. See, e.g., J.G. FICHTE, Science OF Rights (A.E. Kroeger trans., London, Trubner \& Co. 1889) (1796); Hegel, supra note 208, $\S \S 36,57,71,84-85,95,331$; G.W.F. Hegel, Phenomenology OF SPIRIT $\S \S 178-96$ (A.V. Miller trans., Oxford Univ. Press 1977) (5th ed., J. Hoffmeister ed., 1952). See generally Axel Honneth, The Struggle for Recognition (1995); Robert R. Williams, Recognition (1992). For an excellent discussion of recognition and contemporary controversies on campus, see Charles Taylor, The Politics of Recognition, in Multiculturalism And "The Politics of ReCognition” 25-73 (Amy Guttmann ed., Princeton Univ. Press, 1992).

473 For example, in a widely reported case, a black man from Brooklyn, New York, named Christopher Wilson was abducted on January 1, 1993, in a suburb of Tampa, Florida, by three white men, Mark Kohut, Jeffrey Pellett, and Charles Rourk. The three forced Wilson to drive to an isolated field, holding a gun to his side and taunting him with racial insults. They then told him to get out of the car and said, "Now you're going to die, nigger." Ignoring his pleas for mercy, they poured gasoline over him, set him on fire, and departed, leaving beside him a misspelled note reading, "One les nigger, more to go. KKK." Wilson suffered severe burns but survived the attack. Kohut and Rourk were convicted of attempted murder, kidnapping, and armed robbery, and sentenced to life in prison. See 2 Are Given Life Terms For Burning Black Man, N.Y. Times, Oct. 23, 1993, § 1, at 8; Larry Rohter, Brooklyn Man Tells a Florida Jury About 
crime $\mathrm{e}^{474}$ and may result in civil liability for intentional infliction of emotional distress. ${ }^{475}$ Group-based insults constitute one of the most common forms of insulting or "fighting words." 476 And expressions of hatred can be punished as criminal incitement ${ }^{477}$ when they are intended and likely to provoke others to unlawful violence against the targets. ${ }^{478}$

Being Kidnapped and Set Ablaze, N.Y. TIMES, Sept. 4, 1993, § 1, at 7; 3 Whites Charged in Burning of a Black, N.Y. TIMES, Jan. 8, 1993, at A13.

474 See, e.g., United States v. Garner, 985 F.2d 554 (table), 1993 WL 24791 (4th Cir. 1993) (affirming sentence of Ku Klux Klan member under Fair Housing Act, 42 U.S.C. $\S 3631$ (a) (1988), for making written and verbal threats to kill a black coworker, his white girlfriend, and their child unless they moved out of the area; defendant then made an explosive device and told an informant that he planned to destroy the coworker's house with it); State v. Wyant, No. 90-CA-2, 1990 Ohio App. LEXIS 5589, at*3 (Ohio Ct. App. Dec. 6, 1990) (upholding conviction under state aggravated menacing and ethnic intimidation laws of a white man who, after a black man at a neighboring camp site complained to park officials that he was making too much noise, shouted that "we didn't have this problem until those niggers moved in next to us"; "the black motherfucker over there, I will take my gun and kill him"; and "in fact, I will go over there and get his black ass now"), affirmed after remand, 68 Ohio St. 3d 162 (1994).

475 See Restatement, supra note 241, § 46, illus. 20 (going to another's door at night with a mob and threatening to lynch him unless he leaves town).

476 See, e.g., supra notes 453-55 and accompanying text (discussing Gomez v. Hug and Bailey v. Binyon).

477 The facts of Wisconsin v. Mitchell, 508 U.S. 476 (1993), provide a good example. After watching the movie Mississippi Burning with a group of other young black men, Mitchell urged the group to "move on some white people." Id. at 479-80. Shortly thereafter, as a white boy walked past the group, Mitchell said, "There goes a white boy; go get him." Id. He then counted to three and pointed in the boy's direction. See $i d$. The group ran towards the boy and beat him so severely that he remained unconscious for four days. See id. Upon conviction of aggravated battery for inciting the attack, Mitchell was sentenced under a "hate crimes" law providing for enhanced punishment when a defendant intentionally selects his victim on account of race. See id. at 480-81. In Mitchell, the Supreme Court unanimously rejected a First Amendment challenge to such laws. Mitchell did not challenge the conviction itself, however, for his speech clearly constituted unprotected incitement under Brandenburg v. Ohio, 395 U.S. 444 (1969).

478 A 1989 incident at Arizona State University provides a dramatic example of all of these offenses. A fight started between a black student, Toby Wright, and a white fraternity member, Sean Hedgecock, after Hedgecock allegedly said, "Fuck you, nigger." Two dozen fraternity members then emerged from their house and surrounded Wright and two other blacks, chanting racial slurs. The fight was broken up by police, who alleged that Hedgecock continued to shout epithets and threatened to "get those niggers and kill them." Later that night, Hedgecock saw two other black students and shouted, "Those are the niggers! They're back!" Several hundred people then flooded out of nearby fraternity houses and surrounded the blacks, watching while a group of white fraternity members beat them up. The incident is recounted in Jon Wiener, Words 
In addition to personal security and the public peace, hate speech often violates its targets' personality rights. As Gomez v. Hug illustrates, hate speech can inflict severe emotional injury, giving rise to a claim for intentional infliction. ${ }^{479}$ Hate speech may also violate the right to privacy when, for example, it takes the form of anonymous, threatening, or obscene messages or telephone calls. ${ }^{480}$ Finally, hate speech violates the right to equality by denying all these rights on the basis of race or other invidious grounds. ${ }^{481}$

Insofar as they violate these rights of individuals or the community, acts of private hate speech are presumptively wrongful. Under the rights-based theory, they should therefore be held unprotected unless they have sufficient value to justify the injuries that they cause.

As an illustration, consider the classic form of hate speech in the United States - the burning of a cross to express hostility toward racial, ethnic and religious minorities. Suppose that the Ku Klux Klan burns a cross in front of the home of an African-American family that has recently moved into a white neighborhood, in order to terrorize the family and induce them to move. It is difficult to imagine a more serious invasion of personal security. The act will constitute an assault if family members observe it and suffer imminent fear for their safety. It may also violate laws forbidding threats of future violence. If the cross-burning occurs inside the family's yard, it will also infringe their property rights, as well as criminal laws against trespass and arson.

The Klan's conduct also violates the family members' rights of personality. The act is a flagrant and deeply offensive intrusion into their private lives and thus constitutes invasion of privacy. In addition, it is difficult to conceive of a clearer case of intentional infliction of emotional distress through "extreme and outrageous conduct."

Does cross-burning, when directed against particular individuals, have sufficient value to justify the injuries that it causes? Undoubtedly it constitutes a form of

That Wound: Free Speech for Campus Bigots?, 250 The NAtion 272, $272-73$ (Feb. 26, 1990).

479 For the facts of Gomez, see supra notes 453-55 and accompanying text.

480 For examples of such conduct, see United States v. McAninch, 994 F.2d 1380 (9th Cir. 1993) (affirming sentence under 18 U.S.C. $\$ 876$ for mailing threatening communications over many months to people the defendant thought were interracially married); Southern Poverty Law Center, Klanwatch Intelligence ReP., Oct. 1994, at 10 (reporting that three Jewish residents of Reedsport, Oregon, were the targets of antiSemitic graffiti, hate mail and threatening phone calls; the building they rented was later burned); id. at 11 (reporting that black restaurant owner in Polkton, North Carolina, "received five threatening, racist phone calls and two notes bearing 'KKK' and a drawing of a lynching" over a two-month period).

481 Of course, this is a central theme in the critical-race-theory literature on hate speech. See, e.g., MATSUDA ET AL., supra note 471; see also CATHARINE A. MACKINNON, ONLY WORDS (1993) (arguing that hate speech, pornography, and racial and sexual harassment constitute denials of equality). On the right to equality in the rights-based theory, see Heyman, Hate Speech, supra note 472, at lviii-lix. 
self-expression. As we have seen, however, an act of expression cannot be privileged on account of the very aspect that makes it wrongful in the first place. ${ }^{482}$ Individuals have no right to pursue their own self-realization when it is defined in terms of denying the self-realization of others, and is directed toward them.

It might also be argued that the Klansmen's conduct should be privileged because it is intended, at least in part, to express a political view. Even if crossburning is entitled to protection as political speech, however-an issue that I shall come to shortly ${ }^{483}$-it does not follow that this protection should apply to acts directed against particular persons. The Klan could communicate its political message just as effectively by burning a cross elsewhere, without inflicting serious injuries to specific individuals. Or, if this is not true, then the increased effectiveness arises solely from the wrongful aspect of the conduct, the terror and degradation it inflicts on the family. For these reasons, cross-burning directed toward particular persons should not be protected as free expression.

In sum, private hate speech often invades its targets' rights to personality and personal security, as well as the public peace. In such cases, the speech may violate civil or criminal laws against assault, threats, fighting words, incitement, intentional infliction of emotional distress, or invasion of privacy. Under the rightsbased model, such speech generally should be held unprotected by the First Amendment.

\section{b. Is All Wrongful Speech Equal? Hate Speech and the R.A.V. Decision}

Thus far, the argument has treated hate speech in the same way as any other expression that violates general laws for the protection of rights. This leads to the further question of whether there is anything distinctive about hate speech that might justify greater regulation than other instances of wrongful speech. This was a central issue in R.A.V. v. City of St. Paul, ${ }^{484}$ the Supreme Court's most recent decision on the constitutionality of hate speech regulation.

R.A.V. was charged with burning a cross on the lawn of an African-American family, in violation of a St. Paul ordinance making it a misdemeanor to "place[] on public or private property a symbol ..., including, but not limited to, a burning cross or Nazi swastika, which one knows or has reasonable grounds to know arouses anger, alarm or resentment in others on the basis of race, color, creed, religion or gender." 485 The defendant's First Amendment challenge to the ordinance was rejected by the Minnesota Supreme Court, which construed it narrowly to apply only to expression that amounted to fighting words under Chaplinsky. ${ }^{486}$

482 See supra Part III.A.1.

483 See infra Part IV.B.2.

484505 U.S. 377 (1992).

485 Id. at 380 (quoting St. Paul Bias-Motivated Crime Ordinance, St. Paul, Minn. Legis. Code $\S 292.02$ (1990)).

${ }^{486}$ In re Welfare of R.A.V., 464 N.W.2d 507 (Minn. 1991). 
Writing for five members of the U.S. Supreme Court, Justice Antonin Scalia accepted this narrow interpretation of the ordinance. ${ }^{487}$ He further assumed, for purposes of argument, that Chaplinsky remained good law, and that a jurisdiction could prohibit all words that "by their very utterance inflict injury or tend to incite an immediate breach of the peace." 488 Nevertheless, Justice Scalia held the ordinance unconstitutional because it banned not fighting words in general, but rather only those that insulted or provoked violence on the basis of race, color, creed, religion, or gender. ${ }^{489}$ "Selectivity of this sort," he asserted - even within a generally unprotected category of speech-"creates the possibility that the city is seeking to handicap the expression of particular ideas" simply because of hostility toward them. ${ }^{490}$

Justice Scalia conceded, however, that distinctions based on content can legitimately be drawn within an unprotected category of speech when the basis for the distinction "consists entirely of the very reason the entire class of speech ... is proscribable." ${ }^{91}$ For example, "the Federal Government can criminalize only those threats of violence that are directed against the President, . . . since the reasons why threats of violence are outside the protection of the First Amendment . . have special force when applied to the person of the President."492

Our account of hate speech, however, makes clear that the same rationale applies to laws that regulate fighting words, or other unprotected categories of speech, only when they are based on invidious grounds such as race. The reason why these categories (which I shall call "assaultive speech") are unprotected is that they violate the rights of the target, as well as the community's right to the peace. But hate speech denies the target's status as a person and a member of the community, and thereby challenges the very existence of these rights. For this reason, when hate speech takes the form of assaultive speech, it attacks these rights at a much deeper level than do more ordinary forms of assaultive speech, such as mere personal insults. Thus the reasons for restricting assaultive speech "have special force" when applied to hate speech, and regulations limited to such speech should not be regarded as violating the rule against content discrimination. ${ }^{493}$

487505 U.S. at 381.

488 Id.; Chaplinsky v. New Hampshire, 315 U.S. 568, 572 (1942).

489 See 505 U.S. at 391.

490 Id. at 393-94. Four Justices rejected the majority's reasoning, but would have invalidated the ordinance on overbreadth grounds. See id. at 397 (White, J., joined by Blackmun, O’Connor \& Stevens, JJ., concurring in judgment).

491 Id. at 388 .

492 Id.

493 To be sure, the distinction between assaultive speech that denies recognition to others and that which does not do so does not correspond perfectly to the distinction between assaultive speech based on race or other invidious grounds and other assaultive speech. Although it is generally true that assaultive speech based on these group characteristics involves a denial of personhood to a greater or lesser degree, that may not be true in every case. On the other hand, assaultive speech that is not based on 
In response to the contention that the "harms caused by racial, religious, and gender-based invective are qualitatively different from that caused by other fighting words," 494 Justice Scalia replies that, if this is true, it is due entirely to the fact that such harms are "caused by a distinctive idea.... It is obvious that the symbols which will arouse 'anger, alarm or resentment in others on the basis of race, color, creed, religion or gender' are those symbols that communicate a message of hostility based on one of these characteristics."495 But this would be just as true of the hate-based insults that Justice Scalia assumes would be proscribable under a general fighting words statute. Indeed, the harm caused by all fighting words stems from the "message of hostility" that they convey, whether that hostility is directed against the targets personally or against the groups to which they belong. ${ }^{496}$ Thus, the fact that the harms caused by racial, religious, and genderbased insults reflect "a distinctive message" does not mean that they are not more serious than the harms caused by other assaultive speech, or that they do not justify greater regulation.

In short, Justice Scalia's argument that laws like St. Paul's (those that regulate hate speech as a subset of an unprotected category of speech) necessarily involve unjustified content discrimination is unconvincing. Hate speech inflicts deeper injuries to the personhood and rights of its targets than do other forms of assaultive speech, and therefore merits a stronger response. ${ }^{497}$

\section{Public Hate Speech}

Of course, Justice Scalia's ultimate concern in R.A.V. is that hate speech regulations may be aimed at the political message expressed by the speech. This brings us to the most difficult and controversial problem - that of public or political hate speech.

Suppose that, as in the Skokie case, a group of neo-Nazis or Klansmen plan to hold a march wearing full regalia through a predominantly Jewish or AfricanAmerican neighborhood, in order to express their view that such groups should be

these group characteristics may in some cases deny the victim's personhood. But the law often has to draw distinctions that are reasonable even though not exact. Because assaultive speech based on these characteristics generally involves a denial of the victim's right to recognition, while more ordinary assaultive speech generally does not, it is reasonable for the law to distinguish between them on this basis.

494505 U.S. at 424 (Stevens, J., joined by White \& Blackmun, JJ., concurring in judgment).

495 Id. at $392-93$

496 See id. at 408-09 (White, J., concurring in judgment).

497 For a fuller critique of R.A.V., see Heyman, Hate Speech, supra note 472, at xliiixlvi. For other explorations of the case, see Akhil Reed Amar, Comment: The Case of the Missing Amendments: R.A.V. v. City of St. Paul, 106 HARV. L. REV. 124 (1992); Steven H. Shiffrin, Racist Speech, Outsider Jurisprudence, and the Meaning of America, 80 Cornell L. Rev. 43 (1994); Cass R. Sunstein, Words, Conduct, Caste, 60 U. ChI. L. REV. 795, 822-29 (1993). 
subjected to segregation, deportation, or genocide. ${ }^{498}$ Should such expression be protected under the First Amendment? Freedom of speech on political matters is an inherent right of democratic citizenship. As we have seen, however, that right is not absolute, but must be exercised with due regard for the rights of others. ${ }^{499}$ Under the rights-based approach, we must first determine whether the expression violates those rights, and then inquire whether it should nevertheless be protected because of its political character.

\section{a. Is Public Hate Speech Wrongful?}

In view of the history of violence by Nazis and the Ku Klux Klan, the march described above is likely, and may very well be intended, to diminish the personal security of the groups against whom it is directed. This has some bearing on whether the speech is wrongful. Unless the march creates a reasonable fear of violence in the near future, however, its impact on personal security should not be regarded as sufficient to justify regulation.

The march does, however, constitute a serious violation of its targets' rights of personality. By treating them not as persons but as inferior beings who may be oppressed or murdered, such expression may inflict severe distress, or even lasting trauma, on many target-group members. Whether or not it does so, the expression constitutes a fundamental attack on their right to dignity and inviolate personality.

In response, it may be said that the targets can avoid this attack simply by staying away from the march. ${ }^{500}$ This objection might be persuasive if the expression took place in private: individuals cannot legitimately complain of injury to their sensibilities from expression that is communicated only to others and that does not relate to themselves. The objection fails, however, precisely because of the public nature of the speech. Speech that is political and that occurs in public is intended, and must be deemed, to be communicated to the public at large, not merely to those who are present at the time. As citizens, target-group members have both a right and a duty to attend to the political speech of others, while as the targets of such speech they have a compelling interest in doing so. Thus even if they were to stay away from the march, they could hardly avoid its impact.

498 For the Skokie litigation, see Collin v. Smith, 578 F.2d 1197, 1200 (7th Cir.), cert. denied, 439 U.S. 916 (1978); Village of Skokie v. National Socialist Party of America, 373 N.E.2d 21 (Ill. 1978). The controversy generated a rich and extensive literature. See, e.g., Lee C. Bollinger, The Tolerant Society: Freedom of Speech and Extremist Speech in America (1986); Donald Downs, Nazis in Skokie: Freedom, Community, And the First Amendment (1985); Aryeh NeIER, Defending My Enemy: American NAZIS, THE Skokie CASE, AND the Risks of FreEdom (1979); Raphael CohenAlmagor, Harm Principle, Offense Principle, and the Skokie Affair, 41 POL. STUD. 453 (1993), reprinted in HATE SPEECH AND THE CONSTITUTION, supra note 471, at 277-94; Farber, supra note 452.

499 See supra note 361 and accompanying text.

500 See Collin, 578 F.2d at 1206-07. 
It is also true, as Justice Harlan observes in Cohen v. California, ${ }^{501}$ that in public we are "often ... subject to objectionable speech," and that public discourse may not be restricted simply because it offends some listeners. ${ }^{502}$ It would be a serious mistake, however, to conceive of the public realm as one in which personality has no protection. Individuals do not cease to be persons when they participate in the public life of the community, and they should not be required to wholly sacrifice their rights of personality to do so..$^{503}$ It is difficult to imagine a form of public discourse that injures these rights more deeply than does hate speech.

Public hate speech also violates the speakers' duty to others as members of the political community. As we have seen, political speech is a relational right-a right to engage in discourse with one's fellow citizens on issues of common concern. As such, it entails an obligation to respect the corresponding rights of others. ${ }^{504}$ Public hate speech violates those rights by denying recognition to its targets not only as persons but as citizens. In this way, it constitutes an assault on what I shall call their civic personality.

To develop this notion, we should recall our account of personality in general. ${ }^{505}$ The right to personality was rooted in one's awareness of oneself as a free, self-determining being. Personality also had a social dimension, which was constituted by the relationship between the self and others.

Within the social aspect of personality, we can now identify a civic element. Civic personality is constituted by the relationship between the individual and the community. It exists when an individual is conscious of herself as a member of the community, and when she is recognized as such by other members and by the community as a whole. Individuals have a right to civic personality in the same way that they have a right to the other aspects of personhood.

We can now understand how public hate speech violates this right. By denying recognition to its targets, such speech attacks not only their own consciousness of membership in the community, but also the recognition of this status by other members. In both of these ways, hate speech infringes the dignity and inviolability of its targets' civic personality, in addition to any substantive impact it may have on their status in the community. ${ }^{506}$

501403 U.S. 15 (1971).

$502 I d$. at 21 (internal quotation marks omitted).

503 Justice Harlan acknowledges this point to some extent when he observes that restrictions on speech may be justified where "substantial privacy interests are being invaded in an essentially intolerable manner." Id. at 21 . Although he speaks of "privacy," it seems reasonable to extend his statement to include other rights of personality as well, such as personal dignity and emotional well-being.

504 See supra notes 361 and accompanying text.

505 See supra Part II.C.

506 Public hate speech thus inflicts a dignitary wrong analogous to profound insults, which infringe personal dignity, and to defamation, "false light," and misappropriation, which violate the dignity of social personality. See supra Parts II.C.2.c, IV.A.3. 
Public hate speech also violates the rights of the community itself. As we have seen, political discourse is often understood on Meiklejohn's model of the town meeting. ${ }^{507}$ Free speech is essential to reach informed decisions on matters of common concern. At the same time, Meiklejohn stresses that speakers can be required to observe certain rules of order. These rules do not violate freedom of speech, but rather make free deliberation possible. In particular, he observes that "[i]f a speaker ... is abusive or in other ways threatens to defeat the purpose of the meeting, he may be and should be declared 'out of order." 508

It would seem to follow from this view that public hate speech should not be protected under the First Amendment. Like abusive speech in a town meeting, hate speech violates the integrity of the deliberative process by undermining the possibility of reasoned discourse. As Meiklejohn observes, such discourse cannot take place except on the basis of mutual respect among citizens who regard one another as capable of engaging in rational self-government. ${ }^{509}$

Of course, public debate in a large modern society differs in many ways from Meiklejohn's town meeting, and a great deal of speech that would be improper in that setting is considered acceptable within the polity at large. But Meiklejohn's basic insight is a valid one. Democratic self-government is impossible in the absence of a minimal degree of civility and mutual respect among citizens. Although that minimum standard will differ depending on the nature, size, customs, and values of each society, its members must observe such a standard or they cease to constitute a community. And however minimal our society's version of that standard is taken to be, it clearly is violated by speech that denies recognition to others on the basis of race, ethnicity, gender, or religion..$^{510}$

In a democratic polity, citizens not only govern but also are governed. This distinction suggests a further way in which public hate speech is wrongful. For the American constitutional tradition, ultimate sovereignty resides in the people. The community, and the government that it establishes, have an obligation to recognize individuals as persons and citizens, and to respect their fundamental rights. This may be regarded as the core meaning of the Thirteenth and Fourteenth Amendments. But this duty of recognition, I would argue, obliges not only the community itself but also its members. As citizens, individuals are entitled to share in the political power of the community. With this right comes a corresponding obligation to use that power in accordance with the same duties that the

507 See supra notes 358-60 and accompanying text.

508 MEIKLEJOHN, supra note 170, at 24-25.

509 Id. at $69-70$.

510 Of course, this standard is an evolving one. One may hope, for example, that the recent tragic events in Wyoming will lead to a fuller recognition in American society that all individuals are entitled to fundamental human rights without regard to sexual orientation. See, e.g., Hate Mail Lauds Killing of Gay Wyoming Student, CHI. TRIB., Oct. 14, 1998, § 1, at 10 (describing outbreak of anti-homosexual hate speech following brutal murder of Matthew Shepard, a gay University of Wyoming student). 
community itself has. ${ }^{511}$ This duty is owed both to the community itself and to one's fellow citizens.

As rulers, then, citizens have a duty to recognize their fellow citizens in their capacity as ruled, and to use their political power only for the common good and the protection of rights. By engaging in hate speech, a citizen violates this duty of recognition. In addition, if we regard political speech as itself a form of political participation, hate speech may also be understood as a use of political power contrary to the rights of its targets. In these ways, an individual violates his duty as a citizen, just as a legislator would act contrary to his oath if he failed to respect the constitutional rights of citizens.

\section{b. Should Public Hate Speech Be Protected Under the First Amendment?}

The previous section argued that public hate speech is presumptively wrongful for several reasons: it diminishes the personal security of its targets, violates their rights of personal dignity and citizenship, contravenes essential rules of public debate, and breaches the duty of citizens to recognize those over whom they exercise political power. Should such expression nevertheless be protected because of its character as political speech or its contribution to the search for truth? ${ }^{512}$

The protection of political expression is rightly regarded as a core concern of the First Amendment. In my view, however, public hate speech is not entitled to such protection, at least as a matter of substantive right. ${ }^{513}$

At the outset, it is important to stress that the rationale developed here does not contravene the basic principle against political censorship as set forth by Meiklejohn. That principle, as we have seen, holds that

511 The principle on which this argument relies is fundamental and applies in a wide range of situations. When individuals act as a members of a collective body, they are obligated to act in accordance with the obligations that apply to the body as a whole. For example, while Article I and the First Amendment to the Constitution apply to Congress as a whole, each member is required to take an oath to support the Constitution. See U.S. ConST. art. VI, cl. 3. Similarly, individual jurors are required to take an oath to do justice, even though it is the jury as a whole that is ultimately responsible for reaching a just decision.

512 For the reasons already discussed, the general-liberty and individual selfrealization rationales would not support a privilege for public hate speech. A ban on cross-burning and similar expression imposes only a slight restriction on liberty of conduct in comparison with the severity of the injuries that they cause. And, while a Klansman might feel that such expression promotes his self-realization and selfexpression, these values can be largely or wholly satisfied through thought or expression that is not communicated to the targets or to the public in general, unless the Klansman's self-realization depends on negating the self-realization of others-the very reason why the expression is wrongful in the first place.

513 Whether such speech should receive protection for reasons of institutional right is a separate question which is touched upon below. See infra notes 523-27 and accompanying text. On the distinction between substantive and institutional right, see supra notes 224-26 and accompanying text. 
no suggestion of policy shall be denied a hearing because it is on one side of the issue rather than another. And this means that though citizens may, on other grounds, be barred from speaking, they may not be barred because their views are thought to be false or dangerous.... [T] he reason for this equality of status in the field of ideas lies deep in the very foundations of the selfgoverning process. When men govern themselves, it is they-and no one else - who must pass judgment upon unwisdom and unfairness and danger. And that means that unwise ideas must have a hearing as well as wise ones, unfair as well as fair, dangerous as well as safe, un-American as well as American. ${ }^{514}$

Justice Brandeis expresses a similar view in Whitney v. California, ${ }^{515}$ and adds that "[i]f there be time to expose through discussion the falsehood and fallacies, to avert the evil by the processes of education, the remedy to be applied is more speech, not enforced silence." 516

The view expressed by Meiklejohn and Brandeis constitutes an essential element of any adequate theory of free speech. For this reason, a convincing argument for hate speech regulation cannot be based merely on disagreement with the speech or on the danger that it might prevail in public debate. Such a view would disrespect the capacity of the citizenry to determine for themselves that the speech is false, dangerous, and unfair. For this we must rely, as Brandeis says, on more speech. ${ }^{517}$

Instead, the present argument is based on the contention that hate speech violates the rights of others and is therefore wrongful. The key question, then, is whether hate speech, even though it violates these rights, should be protected because of its value as political speech. In my view it should not, for hate speech lacks full value as political speech, and its value does not justify the injuries it causes.

For Brandeis and Meiklejohn, the paradigm case of political speech is expression that is directed by one citizen to the rest of the community and that relates to matters of public policy that it must decide. Political hate speech, however, is not addressed to the citizenry as a whole, but only to a particular group of citizens - for example, those who are white Christians. Of course, the speaker may also intend to address members of the target group. Insofar as she does so, however, she ad-

\footnotetext{
514 Meiklejohn, supra note 170, at 26-27.

515274 U.S. 357, 377 (1927) (Brandeis, J., concurring).

516 Id.

517 As I argue below, however, confidence in the ability of free debate to discern truth and reject injustice depends on certain conditions - in particular, the requirement that individuals recognize one another as free and rational participants in the process. See infra note 521 and accompanying text. In the absence of mutual recognition, there is no sufficient reason to assume that the political process will work as Brandeis and Meiklejohn envision.
} 
dresses them not as citizens - since she does not recognize them as such-but as objects of hatred and contempt. ${ }^{518}$

When hate speech advocates extreme racist measures such as genocide, mass deportation, or enforced segregation, it lacks full political value for another reason as well: it does not relate to a matter of public policy for the people to decide. This is not merely because genocide and other extreme measures would violate constitutional guarantees. The Constitution may be amended; moreover, according to the liberal tradition, the people always retain the right to alter or abolish it. But even if the Constitution were amended or a new one adopted, it could not rightfully empower the government to commit genocide, because genocide is beyond the authority of any legitimate regime.

In sum, political hate speech lacks full value as political speech because it is not addressed to the citizenry as a whole, and because (in cases where it proposes extreme racist measures) it does not relate to a matter for the people to decide. This is not to deny that political hate speech has some value as political speech. Thus, the protection of hate speech is sometimes defended on the ground that it may express genuine grievances or frustrations, although it attributes them to the wrong causes and advocates the wrong solutions; or that it provides useful information about the presence of dangerous views within the community; or that it shows the ugliness of racism in its clearest light; ${ }^{519}$ or that it serves as a stimulus to developing the social virtue of tolerance. ${ }^{520}$

While hate speech may have some political value, that value is distinctly limited. None of these arguments view political hate speech as having value in itself, or because it makes a contribution to political debate that is worthy of respectful consideration. Instead, each of these arguments attributes to hate speech only an indirect value. The expression is to be valued not for what it intends to contribute, but for something that we may be able to find in it. This indirect value does not seem sufficient to justify treating hate speech as privileged in the face of the serious injuries that it causes both to its targets and to the polity itself.

Nor should public hate speech be protected because of its contribution to the pursuit of truth. As I have argued, Justice Holmes's metaphor of the marketplace of ideas is inadequate. Instead, the search for political truth is best understood in

518 Of course, much ordinary political speech is directed not to the public as a whole but to some smaller group of citizens. Insofar as it is political, however, such speech is addressed to individuals as members of the larger polity, and urges them to adopt positions or to take actions within the polity. Such speech constitutes a stage in the broader political process, a step toward interaction with the citizenry as a whole. Political hate speech is different: it does not urge its hearers to engage in political interaction with other citizens in general, but only with those who are not members of the target group. In an important sense, such speech does not address its hearers as members of the political community, but only as members of some smaller group such as white Christians.

519 See Farber, supra note 452, at 301-02.

520 See Bollinger, supra note 498. 
Brandeis' and Meiklejohn's terms, as a process of discussion among free and equal citizens. More generally, the search for truth requires that people recognize one another as reasonable beings who are capable of participating in a common enterprise of inquiring after truth.521 Because hate speech denies recognition to others, it can make no direct contribution to this process. And, once more, while hate speech may have some indirect value in this respect, that value does not seem sufficient to outweigh the injuries that it causes to the rights of others. ${ }^{522}$

\section{Conclusion}

From a rights-based perspective, one may well conclude that there is no substantive right to engage in public hate speech, such as the Nazi march in Skokie. That is not necessarily the end of the matter, however. Even when speech is substantively wrongful, regulation may be inappropriate for institutional reasons. ${ }^{523}$ Objections to hate speech regulation often take this form-for example, that the law is incapable of drawing a sufficiently clear distinction in this context between protected and unprotected speech ${ }^{524}$; that if government had the power to regulate some unpopular expression, there is a great danger that this power would be abused; that the most effective response to hate speech is counterspeech; and that hate speech laws are likely to be counterproductive, aggravating the racism they are designed to combat. ${ }^{525}$

The rights-based theory is not intended to foreclose constitutional or political arguments of this sort. How much force they have is largely a matter of practical judgment, not theoretical reflection. Several observations can be made, however. First, arguments of this sort often rely on the assumption that free speech is "indivisibl[e]" - that "there is no principled basis" for distinguishing hate speech from

521 See supra note 381 and accompanying text.

522 One useful way to explore this question is to ask whether we believe that it is actually desirable that such views be publicly expressed, in the sense that the values underlying free speech and other rights are best served if those who hold such views openly express them, rather than keeping those views to themselves. Meiklejohn, for example, argues that if political views are "responsibly entertained by anyone, we, the voters, need to hear them"; such views "must be expressed, not because they are valid, but because they are relevant." MeIKLEJOHn, supra note 170, at 28. Mill discusses the search for truth in similar terms. See MiLl, supra note 151, at 43-44. It seems highly doubtful, however, that we would apply this position to public hate speech. Instead, we would be more likely to say that such speech is so inconsistent with the respect owed to others and with the requirements of reasonable discussion that it is improper to introduce it into public discourse, regardless of whether there is a right to do so. We would regard the disappearance of hate speech as a gain rather than a loss for public discussion. If this is true, then it is clear that the value of public hate speech does not outweigh the injuries it causes.

523 See supra notes 224-26 and accompanying text.

524 See, e.g., Strossen, supra note 446, at 528.

525 See, e.g., Shiffrin, supra note 497, at 93-102. 
other forms of expression. ${ }^{526}$ If we reject this assumption, such arguments may lose much of their force. Second, even if we were to conclude that there were institutional reasons for protecting hate speech, that would not alter the fact that such speech constitutes a serious invasion of substantive rights. The effect of protecting hate speech on these grounds would be to leave target-group members without legal protection against such injuries. This course should be taken only if, and insofar as, it is necessary from the standpoint of right as a whole. It also follows, finally, that expression that is protected solely for institutional reasons is not necessarily entitled to the same high level of protection as other speech. ${ }^{527}$

However one resolves the difficult issues surrounding public hate speech, it is clear that, under the rights-based theory, there is a realm of thought and expression that is beyond the legitimate reach of the law. Thus freedom of thought can never rightfully be restricted, since a person's inner thoughts can never violate the rights of others. ${ }^{528}$ The same is true of expression that is not communicated to others. This right of private thought and expression probably should also apply to private conversations, and to internal expression within small groups. ${ }^{529}$ Scientific and intellectual inquiry should also be protected; ${ }^{530}$ expression comes within the sphere of law only when it is directed toward affecting the rights of others.

526 Strossen, supra note 446, at 533, 534 .

527 For example, even if institutional concerns barred the government from outlawing public hate speech, it would not necessarily follow that there should be no power to channel such expression so as to minimize its direct impact on target-group members-say, by requiring the Nazis to hold their march somewhere other than in Skokie. For a similar channeling approach to obscenity regulation, see Paris Adult Theatre I $v$. Slaton, 413 U.S. 49, 73, 106-07, 112-13 (1973) (Brennan, J., joined by Marshall \& Stewart, JJ., dissenting) (arguing that obscenity laws should be held unconstitutional on vagueness grounds, but suggesting that states have power to regulate the manner of distribution to protect juveniles and unconsenting adults).

528 See supra Part II.C.3.

529 For example, if a dozen Klansmen wish to gather on their own property to burn crosses and make racist and anti-Semitic speeches, as in Brandenburg v. Ohio, 395 U.S. 444 (1969), they should probably have a First Amendment right to do so. In Brandenburg itself, however, this protection would not apply, because the defendants arranged for a reporter and cameraman to attend the rally so that they could film it and broadcast it on television, thereby making the expression public. See id. at 445 . Of course, this does not mean that the holding of Brandenburg was wrong. As we have seen, Brandenburg held that a state may not proscribe speech on the ground that it advocates unlawful action unless it amounts to imminent incitement. See id. at 447. The argument presented here does not advocate restricting hate speech because it may produce unlawful action (in circumstances broader than those defined by Brandenburg), but rather because it violates a range of rights by denying recognition to others.

${ }^{530}$ For a similar position, see Mari J. Matsuda, Public Response to Racist Speech: Considering the Victim's Story, in MATSUDA ET AL., supra note 471, at 40-41. 


\section{CONCLUSION}

At the heart of contemporary disputes over the First Amendment is an apparent conflict between freedom of expression and other fundamental values such as dignity, equality, and community. This conflict results from the tendency of modern First Amendment theory to conceive of issues in terms of an opposition between free speech and other social interests. Because of the difficulty of finding common ground between these disparate values, First Amendment problems often appear to be intractable.

This Article has offered an alternative account that draws on the natural rights background of the First Amendment. According to this view, free speech is an essential form of human liberty. The same values that justify this right, however - external freedom, individual self-realization, democratic self-government, and the pursuit of truth - also give rise to other fundamental rights. Expression that violates these rights may be regulated except where its value is sufficient to justify the injuries that it causes.

The rights-based theory thus acknowledges what is most powerful in an absolutist approach to the First Amendment-its refusal to compromise the principles underlying free speech - while at the same time recognizing that these principles also justify protection of other rights. The value of free speech is ultimately strengthened rather than weakened by this recognition of its normative limits.

The Article then explored how the rights-based theory would apply to current controversies over insults and hate speech. In addition to any threat they may pose to the public peace, insults may violate their targets' rights to personal dignity and freedom from emotional distress. Hate speech may also violate these rights, as well as those of personal security, equality, and citizenship. Above all, hate speech violates the fundamental right to recognition as a person and a member of the community. Insults and hate speech generally lack value sufficient to outweigh the injuries they cause. For these reasons, they should generally be held unprotected under a rights-based approach to the First Amendment.

In conclusion, let us return to the case with which we began, that of Jake Baker. ${ }^{531}$ Should Baker's publication on the Internet of a story graphically describing the rape, torture, and murder of a woman identifiable as one of his classmates be protected under the First Amendment? If one assumes that, when he posted the story, Baker did not intend for it to be read by anyone who would reasonably regard it as an expression of a serious intention to harm an actual person, he should not be held to have violated criminal laws forbidding threats. It does not follow, however, that his actions should be constitutionally protected. First, his conduct surely caused the woman to fear for her personal safety. If accompanied

531 See supra notes 1-12 and accompanying text. For some other discussions of the case, see Robert Kurman Kelner, Note, United States v. Baker: Revisiting Threats and the First Amendment, 84 VA. L. ReV. 287 (1998); David C. Potter, Note, The Jake Baker Case: True Threats and New Technology, 79 B.U. L. REV. (forthcoming June 1999). 
by other acts, it might give her reasonable grounds to seek a civil remedy, such as an order of protection forbidding Baker to have any contact with her.

Besides their impact on personal security, Baker's actions also violated the woman's rights of personality. In addition to recklessly inflicting severe emotional distress, his conduct constituted a profound violation of her right to personal dignity and inviolability. ${ }^{532}$ Finally, a university might reasonably determine that Baker had violated the standards of conduct it expects of its members. ${ }^{533}$

Of course, Baker's story was a work of fiction, which is generally entitled to First Amendment protection. Writers of fiction are not immune to liability, however, when they infringe the rights of others (for example, by violating a copyright or defaming an identifiable individual). Most importantly, whatever value Baker's story may have had as self-expression or a contribution to the culture, it was not necessary for him to use the name of an actual person. Because his conduct could have achieved the same values without violating the rights of others, it should not be protected under the First Amendment.

This Article has been able to explore how the rights-based theory would apply to only a few First Amendment problems. Many other important questions remain. As I hope this Article has shown, however, the rights-based theory offers a promising approach to developing a more coherent view of the foundations and limits of freedom of expression.

532 In particular, Baker reasonably might be found to have appropriated the woman's name for his own purposes without her consent. See supra note 329 and accompanying text (discussing tort of misappropriation of name or likeness).

533 See, e.g., Stanford University Fundamental Standard ("Students ... are expected to show both within and without the University such respect for order, morality, personal honor and the rights of others as is demanded of good citizens. Failure to do this will be sufficient cause for removal from the University."), quoted in Thomas C. Grey, Civil Rights vs. Civil Liberties: The Case of Discriminatory Verbal Harassment, 8 Soc. PHIL. \& Policy, Spring 1991, at 81, 106. 